\title{
Assessing Environmental Contaminant Threats to Lands and Biota Managed by the U.S. Fish and Wildlife Service
}

\author{
By \\ James Coyle ${ }^{1}$ \\ Craig Moore ${ }^{2}$ \\ Sky Bristol ${ }^{3}$ \\ Mary Henry, Ph.D. ${ }^{2}$ \\ Tim Hall ${ }^{4}$ \\ Tim Kubiak ${ }^{2}$
}

Open File Report 99-108

\footnotetext{
Midcontinent Ecological Science Center

Fort Collins, CO 80525

${ }^{2}$ U.S. Fish and Wildlife Service

Division of Environmental Contaminants

Region 9 Headquarters

Arlington, VA 22203

${ }^{3}$ U.S. Fish and Wildlife Service

Division of Environmental Contaminants

Albuquerque Field Office

Albuquerque, NM 87113

'U.S. Fish and Wildlife Service

Endangered Species

Region 9 Headquarters

Arlington, VA 22203
}

${ }^{1}$ U.S. Geological Survey Biological Resources Division

Office of Science, Biomonitoring of Environmental Status and Trends Program 


\section{FORWARD}

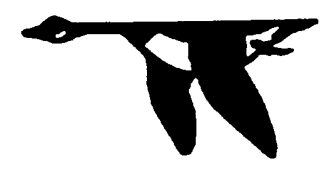

This document represents the culmination of several years of collaborative work between the U.S. Fish and Wildlife Service (FWS) and the U.S. Geological Survey (USGS). The Contaminant Assessment Process (CAP) and its supporting data management system provide a logical structure for organizing and interpreting information from the databases maintained by the Environmental Protection Agency (EPA) and the FWS. These powerful tools will augment FWS's ability to evaluate contaminant threats to national wildlife refuges. As the National Wildlife Refuge System embarks upon development of Comprehensive Conservation Plans in response to the passage of the National Wildlife Refuge System Improvement Act of 1997, CAP will provide timely and relevant inventories of contaminant threats, to trust resources and Service lands. This will contribute to a significantly holistic refuge evaluation approach.

The FWS gratefully acknowledges contributions to this effort by the USGS Biomonitoring of Environmental Status and Trends (BEST) Program. The BEST Program worked closely with the FWS to develop the technical guidance and contributed to the initial development and subsequent refinement of the data management system for the CAP. Innovative programming codes for the data management system were developed under contract at the USGS Midcontinent Ecological Science Center.

Lastly, this guide is a "living document" and will be updated periodically to reflect improvements recommended by refuge managers, biologists, or contaminant specialists. Good luck in your efforts. We hope that this guide and the improved data management system that it embodies, will facilitate your Refuge contaminant assessments and help illuminate contaminant threats to the Nation's resources.

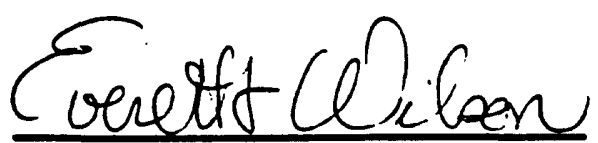

Everett Wilson, Chief

Division of Environmental Contaminants

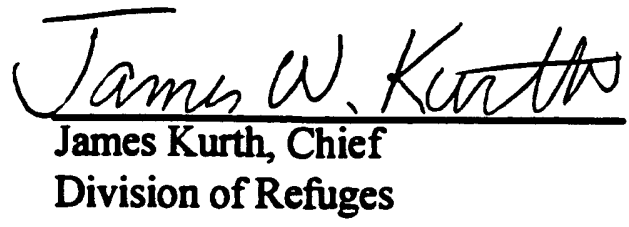

James Kurth, Chief

Division of Refuges 


\section{Preface}

The Contaminant Assessment Process (CAP) is a standardized approach for documenting and assessing threats posed by environmental contaminants to lands and biota managed by the Department of the Interior (DOI). The Biomonitoring of Environmental Status and Trends (BEST) Program of the U.S. Geological Survey Biological Resources Division (USGS/BRD) developed the CAP cooperatively with the U.S. Fish and Wildlife Service's (FWS) Division of Environmental Contaminants (DEC). The CAP involves two parts, a retrospective analysis, and if needed, field-sampling. The retrospective analysis documents the ecological characteristics, management goals, areas potentially vulnerable to hazardous substance spills, and habitats of importance for the DOI land unit of interest. In addition, contaminant transport pathways and sources (point and nonpoint) are identified and potentially contaminated areas delineated. The second part of the CAP involves developing field-sampling plans to confirm the presence or effects of contaminants identified in the retrospective analysis. Field-sampling deemed necessary to confirm contaminant issues on national wildlife refuges identified through the retrospective analyses of CAP is handled as part of DECs on- and off-refuge investigation programs.

By gathering and interpreting information, the CAP generates valuable insight regarding contaminant issues that may be affecting refuges. Findings from the CAP can help FWS stewards select options that reduce contaminant impacts on the habitats and species that they manage. Information synthesized through the CAP also contributes to the development of Comprehensive Conservation Plans mandated through the National Wildlife Refuge System Improvement Act of 1997. To insure that this information has the maximum benefit to the agency, DEC and the BEST Program jointly developed a data management system to support the CAP. This system facilitates information acquisition from remote sources and serves as a permanent data repository. Thus, the system documents CAP findings, enhances FWS's institutional memory, and supports informed management decisions.

This document is a user's guide, intended for use by FWS field biologists responsible for applying the retrospective analysis portion of the CAP to FWS national wildlife refuge lands and provides instructions for entering information into the data management system. This is the third revision of the original document written in 1993 by scientists of the Idaho National Engineering and Environmental Laboratory. 


\section{Acknowledgments}

The authors are grateful to Ron Rope and Bob Breckenridge (Center for Environmental Monitoring and Assessment, EG\&G Idaho, Inc., Idaho Falls, Idaho), for producing the original document, which is the foundation for this guide. The authors also wish to acknowledge Larry Gamble (FWS/DEC Region 6 Regional Office, Lakewood, $\mathrm{CO}^{1}$ ) who led efforts to improve the original approach and supervised the early development of the data management system. Development of this guide involved contributions and commitment from numerous individuals from FWS/DEC and USGS/BRD. In particular, we appreciate reviews of the document provided by:

Charlie Chandler

Mike Coffey

Susan Finger

Philip Johnson

Greg Linder

Diane Mann-Klager

George Noguchi

Pedro Ramirez

Allen Robison

Damian Shea

Elaine Snyder-Conn

Dave Warburton
FWS/DEC Region 9 Headquarters, Arlington, VA

FWS/DEC Rock Island Field Office, Rock Island, IL

USGS/BRD Columbia Environmental Research Center, Columbia, MO

FWS/ DEC Region 7 Regional Office, Anchorage, AK

Heron Works, Brooks, OR

FWS/DEC New York Field Office, Cortland, NY

FWS/DEC Region 9 Headquarters, Arlington, VA

FWS/DEC Wyoming Field Office, Cheyenne, WY

FWS/DEC Region 4 Regional Office, Atlanta, GA

North Carolina State University, Department of Toxicology, Raleigh, NC

FWS/DEC Klamath Basin Fish and Wildlife Office, Klamath Falls, OR

FWS/DEC Twin Cities Field Office, Bloomington, MN

The following individuals made valuable contributions during earlier revisions of the document.

Tim Bartish

Wayne Crayton

Bill Gould

Bryan Pridgeon

Laurie Richardson

Chris Schmitt

Valaine Glooschenko

Henry Short

Wayne Willford
USGS/BRD BEST Program, Office of Science, Ft. Collins, $\mathrm{CO}^{1}$

U.S. Army Corps of Engineers, Anchorage, AK $^{1}$

University of New Mexico, Las Cruces, NM ${ }^{1}$

FWS/ES Tampa Field Office, Tampa, FL ${ }^{1}$

FWS/ES Olympia Field Office, Olympia, WA ${ }^{1}$

USGS/BRD Columbia Environmental Research Center, Columbia, MO $^{1}$

Former BEST Program Staff ${ }^{2}$

Former BEST Program Staff ${ }^{2}$

Former BEST Program Staff ${ }^{2}$

The data entry screen examples used in this document were derived from CAP files completed by Susan Blackford (FWS/DEC Kansas Field Office, Manhattan, KS) and Jay Davis (FWS/DEC, Washington Field Office, Lacy, WA). Patrick Anderson (BEST Program Staff, Ft. Collins, CO) helped improve and refine the CAP data management system and contributed to the appendices of this document. Christine Bunck (BEST Program Manager, Madison, WI) provided continued leadership and long-term support during the development of the data management system and the preparation of this document. We also wish to thank Duane Asherin, Jennifer Shoemaker, Dora Medellin, Earlene Swann and Dale Crawford (who contributed the cover artwork) of the USGS Midcontinent Ecological Science Center for their excellent technical and editorial assistance during the second and third revisions of the document.

\footnotetext{
${ }^{1}$ Affiliations and locations at time of publication.

${ }^{2}$ Current contact information not available.
} 


\section{Contents}

Page

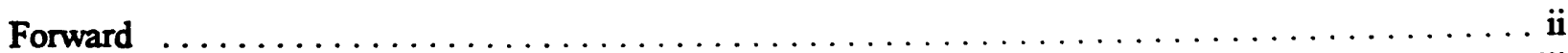

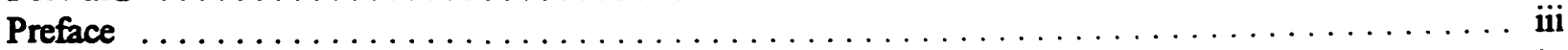

Acknowledgments $\ldots \ldots \ldots \ldots \ldots \ldots \ldots \ldots \ldots \ldots \ldots \ldots \ldots \ldots \ldots \ldots$ iv

Part I: Background Information and Getting Started

Chapter 1. Introduction $\ldots \ldots \ldots \ldots \ldots \ldots \ldots \ldots \ldots \ldots \ldots \ldots \ldots \ldots \ldots \ldots \ldots \ldots$

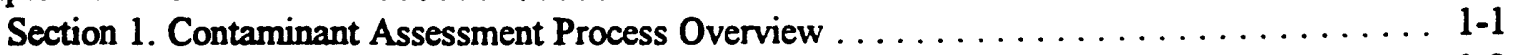

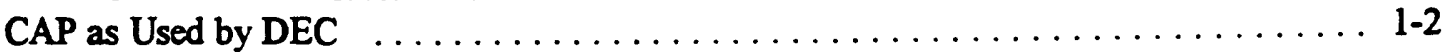

Section 2. Purpose and Scope of this Document $\ldots \ldots \ldots \ldots \ldots \ldots \ldots \ldots \ldots \ldots$

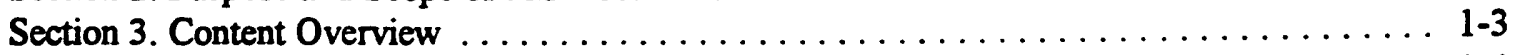

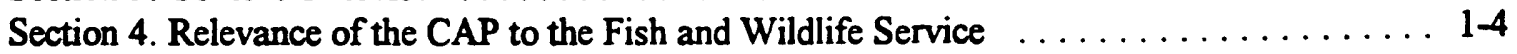

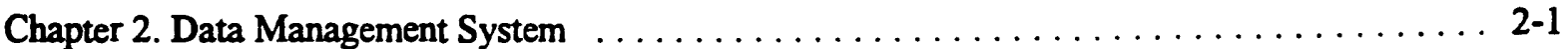

Section 1. Overview of Data Management System $\ldots \ldots \ldots \ldots \ldots \ldots \ldots \ldots \ldots$

Section 2. Accessing the Data Management System and Data Entry

Process Overview . . . . . . . . . . . . . . . . . . . . . . . . . . . 2-2

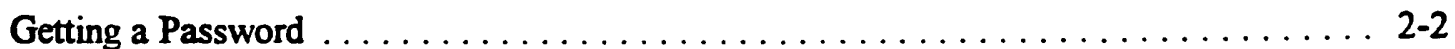

Accessing the Internet CAP Data Management System $\ldots \ldots \ldots \ldots \ldots \ldots \ldots \ldots \ldots$

Starting a New CAP File . . . . . . . . . . . . . . . . . $\ldots \ldots \ldots$

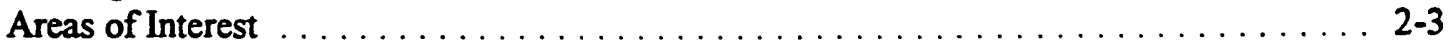

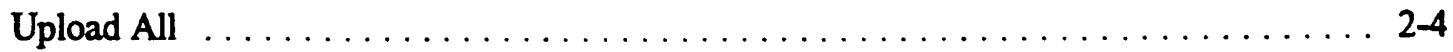

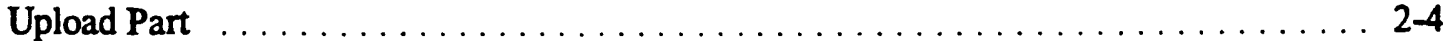

Upload Data from a Completed Study into a New Study . . . . . . . . . . . . . 2-6

Reviewing and Editing On-going and Completed CAP Studies $\ldots \ldots \ldots \ldots \ldots \ldots$ 2-6

Copying and Pasting Information into the Data Management System . . . . . . . . . 2-6

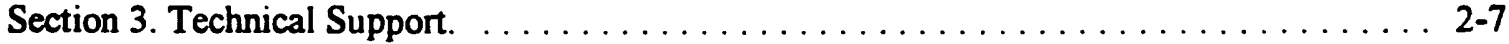

Connectivity and Browser Compatibility Questions $\ldots \ldots \ldots \ldots \ldots \ldots \ldots \ldots$ 2-7

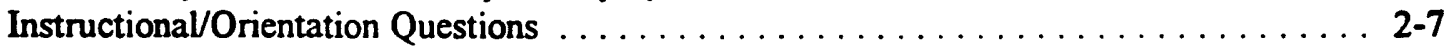

Technical Questions or Difficulties Using the Data Management System . . . . . . . 2-7

Interpretive/Process Questions . . . . . . . . . . . . .

Section 4. Periodic Modifications of the CAP Data Management System . . . . . . . . . 2-8

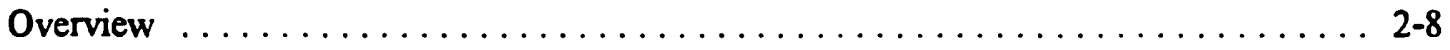

Recommendations for Improving the Process or the Data Management System . . . . . 2-8

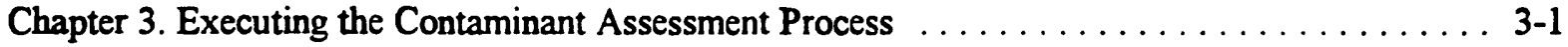

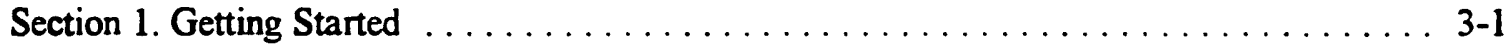

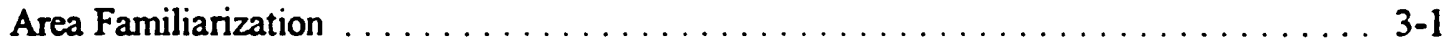

Familiarization with the Data Management System $\ldots \ldots \ldots \ldots \ldots \ldots \ldots \ldots$ 3-1

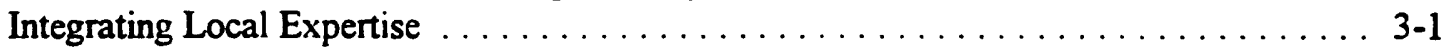

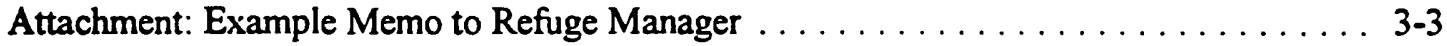

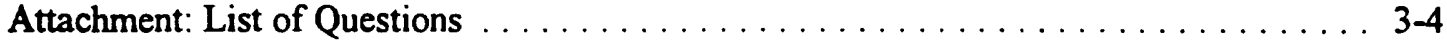




\section{Contents (continued)}

\section{Part II: Guidance for Completing CAP and Data Entry}

Chapter 1. Primary Investigator $\ldots \ldots \ldots \ldots \ldots \ldots \ldots \ldots \ldots \ldots \ldots \ldots \ldots \ldots \ldots$

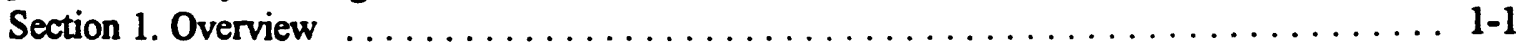

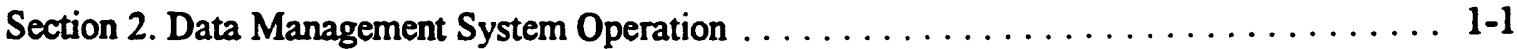

Section 3. Guidance for Data Entry and Analysis: Primary Investigator $\ldots \ldots \ldots \ldots \ldots$ 1-2

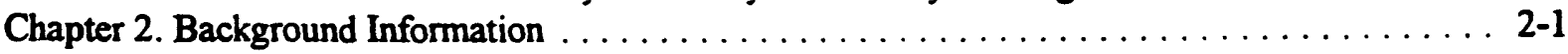

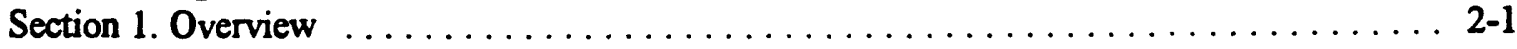

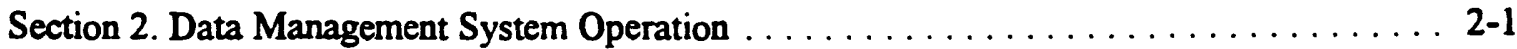

Section 3. Guidance for Data Entry and Analysis: Literature References . . . . . . . . . 2-4

Section 4. Guidance for Data Entry and Analysis: Contacts . . . . . . . . . . . . . . . 2-6

Section 5. Guidance for Data Entry and Analysis: Meetings . . . . . . . . . . . . 2-10

Chapter 3. Assessment Considerations . . . . . . . . . . . . . . . . . . . . 3-1

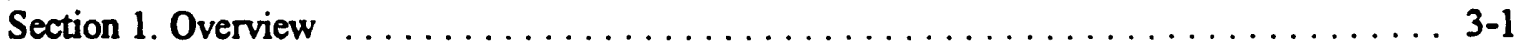

Section 2. Data Management System Operation . . . . . . . . . . . . . . . . 3-1

Section 3. Guidance for Data Entry and Analysis: General Information . . . . . . . . . . 3-2

Section 4. Guidance for Data Entry and Analysis: Species Assessment . . . . . . . . . . 3-6

Section 5. Guidance for Data Entry and Analysis: Land Cover/Land Use . . . . . . . . . . . 3-10

Section 6. Guidance for Data Entry and Analysis: Management Activity . . . . . . . . . . . 3-14

Chapter 4. Local Off-Interior Areas Important to Trust Resources and Assessment . . . . . . . . 4-1

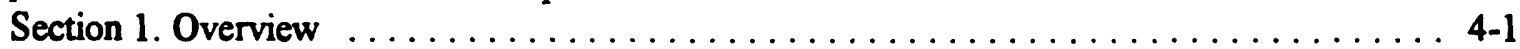

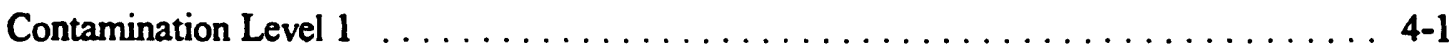

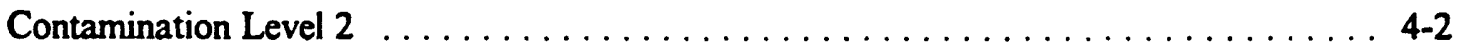

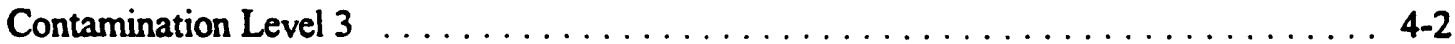

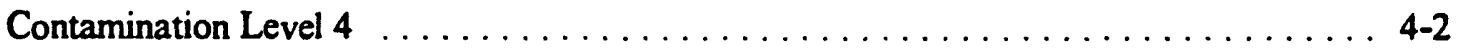

Section 2. Data Management System Operation . . . . . . . . . . . . . . . . . 4-3

Section 3. Guidance for Data Entry and Analysis: Local Off-Interior Lands Important

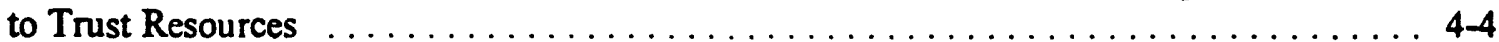

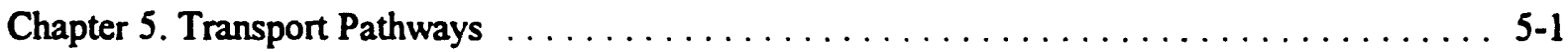

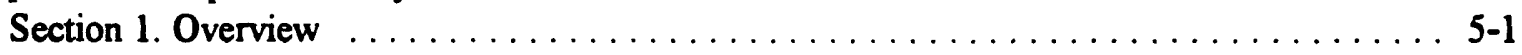

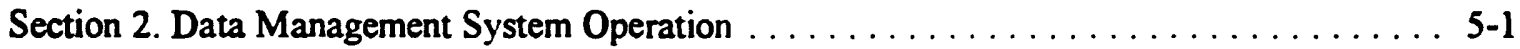

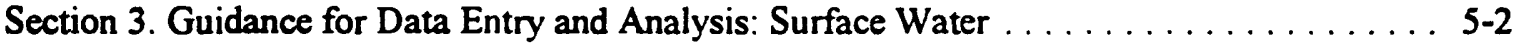

Section 4. Guidance for Data Entry and Analysis: Ground Water . . . . . . . . . . . . . . . . 5 5-6

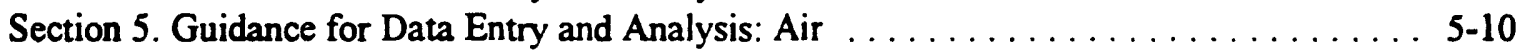

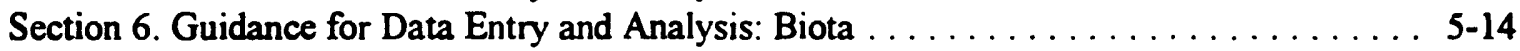

Chapter 6. Contaminant Source Information . . . . . . . . . . . . . . . . . . . . 6-1

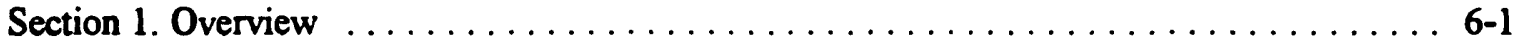

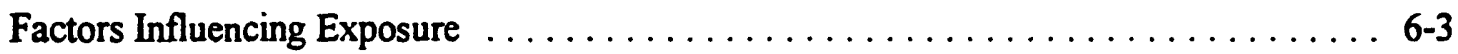

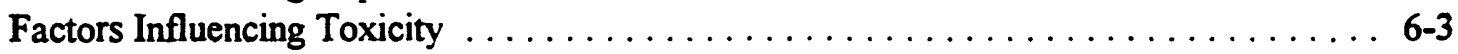

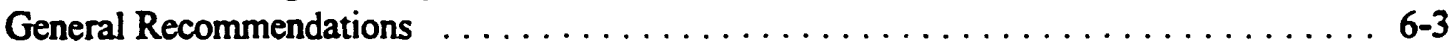


Section 2. Data Management System Operation ...................... 6-4

Selecting and Reviewing Facility Information $\ldots \ldots \ldots \ldots \ldots \ldots \ldots \ldots, 6,4$

Eliminating and Retaining Facilities $\ldots \ldots \ldots \ldots \ldots \ldots \ldots \ldots, 6,4$

Summary of Contaminant Sites . . . . . . . . . . . . .

Contaminant Sites Summarized by Transport Pathway $\ldots \ldots \ldots \ldots \ldots \ldots \ldots \ldots$ 6-5

Internal System Links .................................. 6-5

Caution: EPA Contaminant Source Coordinates . . . . . . . . .

Refine Selection Option . . . . . . . . . . . . . . . .

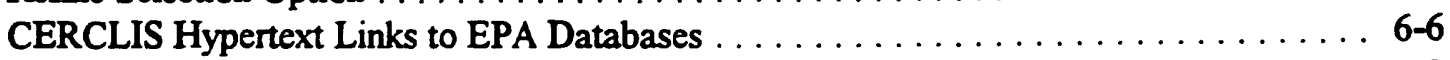

Section 3. Guidance for Data Entry and Analysis: Contaminant Source Information . . . . . 6-8

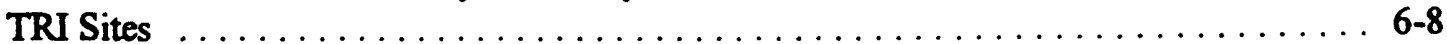

PCS/NPDES Sites $\ldots \ldots \ldots \ldots \ldots \ldots \ldots \ldots \ldots \ldots \ldots \ldots \ldots \ldots \ldots \ldots \ldots \ldots, 14$

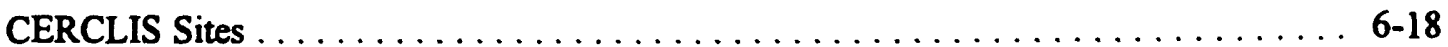

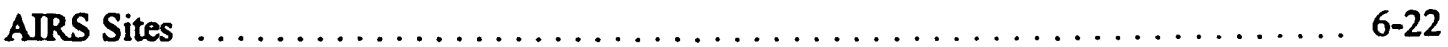

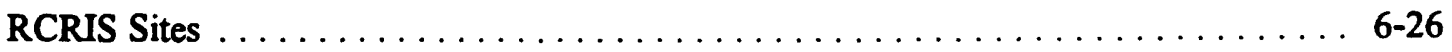

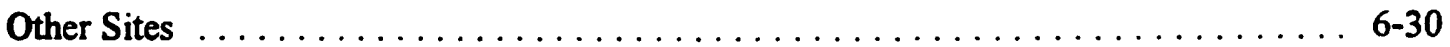

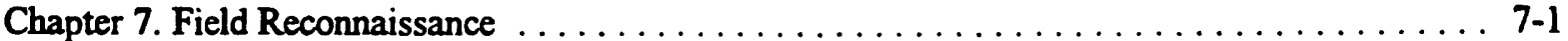

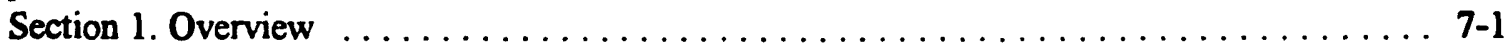

Suggested On-Refuge Areas for Site Visits $\ldots \ldots \ldots \ldots \ldots \ldots \ldots \ldots \ldots \ldots \ldots \ldots \ldots \ldots \ldots, 2$

Suggested Off-Refuge Areas for Site Visits $\ldots \ldots \ldots \ldots \ldots \ldots \ldots \ldots \ldots \ldots \ldots \ldots, 7,2$

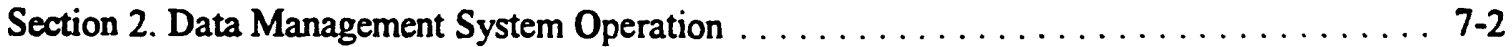

Section 3. Guidance for Data Entry and Analysis: Field Reconnaissance $\ldots \ldots \ldots \ldots \ldots$ 7-4

Chapter 8. Potentially Contaminated Areas $\ldots \ldots \ldots \ldots \ldots \ldots \ldots \ldots \ldots \ldots$. 8 8-1

Section 1. Overview $\ldots \ldots \ldots \ldots \ldots \ldots \ldots \ldots \ldots \ldots \ldots \ldots \ldots \ldots$ 8-1

Possible PCA Locations $\ldots \ldots \ldots \ldots \ldots \ldots \ldots \ldots \ldots \ldots \ldots \ldots \ldots \ldots . \ldots \ldots, 1$

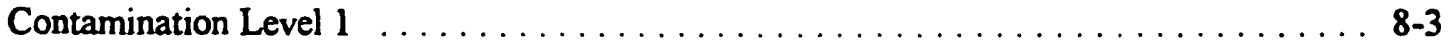

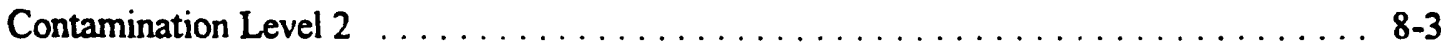

Contamination Level $3 \ldots \ldots \ldots \ldots \ldots \ldots \ldots \ldots \ldots \ldots \ldots \ldots \ldots \ldots$

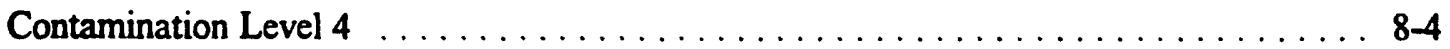

Section 2. Data Management System Operation . . . . . . . . . . . . . . . . . 8 8-4

Section 3. Guidance for Data Entry and Analysis: Potentially Contaminated Areas . . . . . . 8 8-6

Chapter 9. Spill Sensitive Areas . . . . . . . . . . . . . . . . . . . . . . . .

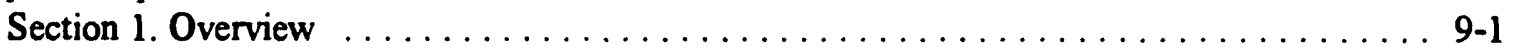

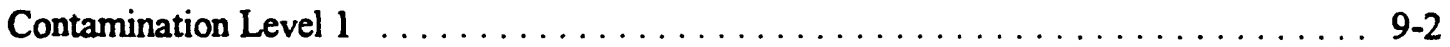

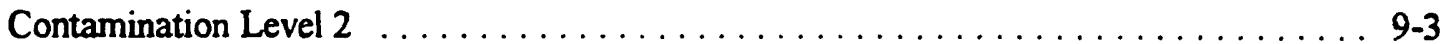

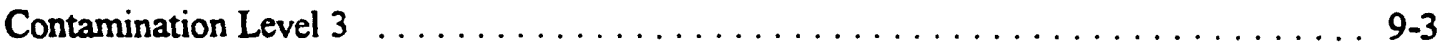

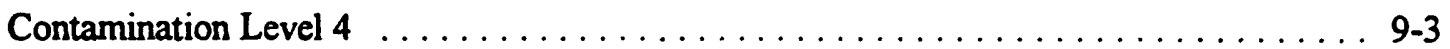

Section 2. Data Management System Operation .................... 9-3

Section 3. Guidance for Data Entry and Analysis: Spill Sensitive Areas $\ldots \ldots \ldots \ldots .9-4$ 


\section{Contents (concluded)}

Chapter 10. Narrative Report of Findings . . . . . . . . . . . . . . . . . .

Section 1. Overview ................................. 10-1

Section 2. Data Management System Operation . . . . . . . . . . . . . . . . 10-2

Section 3. Guidance for Data Entry and Analysis: Narrative Report of Findings . . . . . 10-4

Appendix A. Data Collection Checklist . . . . . . . . . . . . . . . . . . . A

Appendix A. Description of EPA Databases Accessed by the CAP Data

Management System and Online Fate and Effects Information Sources . . . . . . . . . B-1

Appendix C. Definition of Terms $\ldots \ldots \ldots \ldots \ldots \ldots \ldots \ldots \ldots \ldots \ldots \ldots \ldots \ldots \ldots$ 


\section{List of Tables}

Number

Page

\section{Part II: Guidance for Completing CAP and Data Entry}

1-1 Field Descriptions and Examples: Primary Investigator $\ldots \ldots \ldots \ldots \ldots \ldots \ldots \ldots$

2-1 Field Descriptions and Examples: Background Information - Literature References . . . 2-4

2-2 Field Descriptions and Examples: Background Information - Contacts . . . . . . 2-8

2-3 Field Descriptions and Examples: Background Information - Meetings $\ldots \ldots \ldots$ 2-12

3-1 Field Descriptions and Examples: Assessment Considerations - General Information . . . 3-4

3-2 Field Descriptions and Examples: Assessment Considerations - Species Assessment . . . . 3-8

3-3 Field Descriptions and Examples: Assessment Considerations - Land Cover/Land Use . . 3-12

3-4 Field Descriptions and Examples: Assessment Considerations - Management Activity . . 3-16

4-1 Field Descriptions and Examples: Local Off-Interior Lands Important to Trust Resources 4-4

5-1 Field Descriptions and Examples: Transport Pathways - Surface Water . . . . . . . 5-4

5-2 Field Descriptions and Examples: Transport Pathways - Ground Water . . . . . . . 5-8

5-3 Field Descriptions and Examples: Transport Pathways - Air . . . . . . . . . . . . 5-12

5-4 Field Descriptions and Examples: Transport Pathways - Biota . . . . . . . . . . 5-16

6-1 Field Descriptions and Examples: Contaminant Source Information - TRI Sites _ . . . 6-8

6-2 Field Descriptions and Examples: Contaminant Source Information - PCS/NPDES Sites 6-14

6-3 Field Descriptions and Examples: Contaminant Source Information - CERCLIS Sites . . 6-18

6-4 Field Descriptions and Examples: Contaminant Source Information - AIRS Sites . . . 6-22 


\section{Tables (concluded)}

Number $\quad$ Page

6-5 Field Descriptions and Examples: Contaminant Source Information - RCRIS Sites ‥ 6-26

6-6 Field Descriptions and Examples: Contaminant Source Information - Other Sites . . . 6-30

7-1 Field Descriptions and Examples: Field Reconnaissance $\ldots \ldots \ldots \ldots \ldots \ldots \ldots$

8-1 Field Descriptions and Examples: Potentially Contaminated Areas $\ldots \ldots \ldots \ldots$ 8-6

9-1 Field Descriptions and Examples: Spill Sensitive Areas $\ldots \ldots \ldots \ldots \ldots \ldots$ 9-4

10-1 Field Descriptions and Examples: Narrative Report of Findings $\ldots \ldots \ldots \ldots \ldots$ 10-4 


\section{List of Figures}

Number

Page

Part I: Background Information and Getting Started

2-1 CAP Data Management Overview ... . . . . . . . . . . . .

Part II: Guidance for Completing CAP and Data Entry

1-1 Data Entry Screen: Primary Investigator $\ldots \ldots \ldots \ldots \ldots \ldots \ldots \ldots \ldots \ldots \ldots \ldots \ldots$

2-1 Data Entry Screen: Background Information - Literature References $\ldots \ldots \ldots \ldots \ldots$ 2-5

2-2 Data Entry Screen: Background Information - Contacts $\ldots \ldots \ldots \ldots \ldots \ldots \ldots \ldots$

2-3 Data Entry Screen: Background Information - Meetings $\ldots \ldots \ldots \ldots \ldots \ldots \ldots$ 2-13

3-1 Data Entry Screen: General Information - Biodiversity . . . . . . . . $\ldots \ldots \ldots \ldots$ 3-5

3-2 Data Entry Screen: Assessment Considerations - Species Assessment . . . . . . . . . . . 3-9

3-3 Data Entry Screen: Assessment Considerations - Land Cover/Land Use . . . . . . . . 3-13

3-4 Data Entry Screen: Assessment Considerations - Management Activity . . . . . . . . 3-17

4-1 Data Entry Screen: Local Off-Interior Lands Important to Trust Resources . . . . . . . 4-5

5-1 Data Entry Screen: Transport Pathways - Surface Water $\ldots \ldots \ldots \ldots \ldots \ldots \ldots$ 5-5

5-2 Data Entry Screen: Transport Pathways - Ground Water . . . . . . . . . . . . . 5-9

5-3 Data Entry Screen: Transport Pathways - Air . . . . . . . . . . . . . . . . 5-13

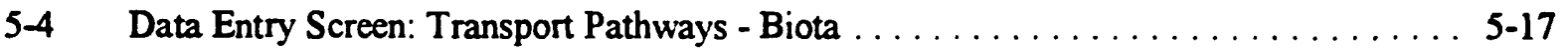

6-1 Data Entry Screen: Contaminant Source Information - TRI Sites . . . . . . . . . . 6-9

6-2 Data Entry Screen: Contaminant Source Information - PCS/NPDES Sites . . . . . . . . 6-15

6-3 Data Entry Screen: Contaminant Source Information - CERCLIS Sites . . . . . . . . 6-19

6-4 Data Entry Screen: Contaminant Source Information - AIRS Sites . . . . . . . . . . 6-23 


\section{Figures (concluded)}

Number Page

6-5 Data Entry Screen: Contaminant Source Information - RCRIS Sites $\ldots \ldots \ldots \ldots \ldots$ 6-27

6-6 Data Entry Screen: Contaminant Source Information - Other Sites ........... 6-31

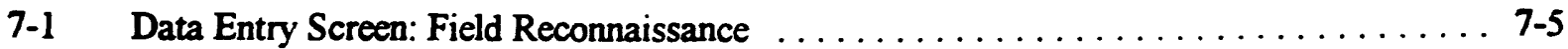

8-1 Data Entry Screen: Potentially Contaminated Areas $\ldots \ldots \ldots \ldots \ldots \ldots \ldots$ 8-7

9-1 Data Entry Screen: Spill Sensitive Areas $\ldots \ldots \ldots \ldots \ldots \ldots \ldots \ldots \ldots \ldots$ 9-5

10-1 Data Entry Screen: Narrative Report of Findings $\ldots \ldots \ldots \ldots \ldots \ldots \ldots \ldots$ 


\section{PART I: BACKGROUND INFORMATION AND GETTING STARTED}


Chapter 1. introduction

\section{Section 1. Contaminant Assessment Process Overview}

This chapter provides an overview of the origin and purpose of the Contaminant Assessment Process (CAP). It summarizes the development of the data management system that facilitates the assessment process and scope and purpose of this document. It also describes how the U.S. Fish and Wildlife Service (FWS) Division of Environmental Contaminants (DEC) and Division of Refuges and Wildlife (DRW) uses the CAP to address contaminant issues on FWS-managed lands.

The CAP is a standardized and comprehensive approach used to assess potential threats posed by environmental contaminants to National Wildlife Refuges (NWRs), national parks, and other lands managed by the Department of the Interior (DOI). The CAP is based on an approach originally developed by Rope and Breckenridge (1993) to evaluate the distribution of contaminants and their effects on NWRs. The CAP has since been refined by the Biomonitoring of Environmental Status and Trends (BEST) Program in the Biological Resources Division of the U.S. Geological Survey (USGS/BRD) and FWS/DEC.

The CAP is divided into two parts, a retrospective analysis and, if needed, subsequent field sampling. The retrospective analysis part of the process involves reviewing administrative, ecological, and geophysical characteristics of the DOI-managed units and surrounding areas relative to contaminant issues. Literature citations and background information related to contaminant issues are compiled for the unit and surrounding area. The spatial extent of the analysis is delineated, potential transport pathways identified, and point and nonpoint contaminant sources and types inventoried. Field reconnaissance surveys are conducted to evaluate suspected contaminant issues. Areas of potential contamination are identified and contaminant issues described.

The second part of the CAP involves field-sampling to further evaluate potential problems or establish baseline conditions. Information collected in the retrospective analysis is used to define sampling objectives, select appropriate methods, and develop focused sampling designs. Field-sampling results are interpreted and findings reported to land managers. Field-sampling considered necessary to confirm the presence or effects of contaminant on NWRs identified through the retrospective analysis of CAP is handled as part of FWSs on- and off-refuge investigation programs.

The CAP is a stand-alone approach based on sound scientific principles. Because it incorporates site-specific characteristics into the analysis, it is flexible enough to identify potential contaminant issues on FWS refuges across a wide range of ecosystems. This approach, consistently applied, will ultimately provide an inventory of existing or potential contaminant issues for all FWS-managed lands. 
Ideally, the CAP should be completed by a environmental contaminant (EC) specialist working in partnership with a landmanager/biologist representing the refuge under consideration. While the interpretation of contaminant information rests mainly with the EC specialist who acts as the Primary Investigator, the overall quality of the assessment will be greatly enhanced through the participation and expertise of refuge managers and biologists.

The information summarized through the CAP can provide the basis by which land managers select options to reduce contaminant impacts on the habitats and species they administer. The CAP also identifies FWS-managed areas located downstream or down-gradient from highways, railways, or navigation channels that may be vulnerable to hazardous substance spills. Such areas may then be targeted for baseline data collection which could support future natural resource damage assessments. While the CAP provides a robust assessment of potential contaminant issues, it is not intended to statistically characterize contaminant distribution or effects across the entire FWS-managed unit.

The CAP requires the Primary Investigator to compile and interpret information acquired from various sources. In 1996, BEST and DEC jointly developed a data management system to support the retrospective analyses portion of the CAP. The data management system retrieves and organizes information from on-line databases maintained by the Environmental Protection Agency (EPA) and internally maintained databases of the FWS. In addition to this information, the CAP requires that the Primary Investigator acquire data from other sources including interviews with refuge managers, biologists, local and subject matter experts, and literature reviews. By accessing information from remote sources and administering user input, the data management system serves both as an information acquisition tool and archive. The data management system documents the basis of the CAP findings and enhances FWS's institutional memory and increases accessibility to the information.

Once the initial assessment is conducted, changes in land use and point and nonpoint contaminant sources on and off the refuge are inevitable. It is anticipated that following completion of the initial assessment, the CAP will be periodically updated. Reevaluation of existing and new information will improve the likelihood that contaminant problems will be identified before they cause serious injury or loss of natural resources. Repeating the CAP after the initial effort will become progressively easier, faster, and less time-intensive.

CAP as Used by DEC

The mission of the DEC is to prevent, investigate, and when appropriate, mitigate the adverse impacts of environmental contaminants on trust resources. As part of its strategy to meet this mandate, DEC uses the retrospective analysis portion of CAP to 
Section 2. Purpose and Scope of this Document

\author{
Section 3. Content \\ Overview
}

identify potential contaminant issues on refuges. As applied by DEC, the final output of CAP is a narrative report of contaminant issues potentially affecting the refuge. Information summarized in the narrative report can contribute to the conservation planning process mandated through the National Wildlife Refuge System Improvement Act of 1997. Field sampling deemed necessary to confirm contaminant issues identified through the retrospective analysis of CAP are handled as part of DECs on- and off-refuge investigation programs.

This user's guide describes the steps and rationale for completing the retrospective analysis portion of the CAP and the process for entering pertinent information into the data management system. It is intended primarily for use by FWS EC specialists and other assessment team members responsible for applying the retrospective analysis to FWS-managed lands. It lists the information required to complete the process, provides format guidance, examples of data entries, and a description of how the information supports the assessment. This guide provides points of contact for users with technical and process questions relating to the process and data entry procedures. It provides an overview of the automated functions performed by the data management system, including a description of remote data sources accessed by the data management system. It also summarizes the relevance of CAP to FWS's mission.

This document is divided into two parts. The first chapter of Part One summarizes the development of the process. It describes the relevance of CAP to the FWS and describes the purpose and scope of this document. The second chapter contains an overview of the data management system, including general access and data entry procedures. The third chapter provides insights and recommendations on how to gather, organize, and enter the relevant information into the data management system to complete a CAP.

Part Two of the document is divided into 10 chapters, one for each of the 10 information sections that make up the data management system. Each chapter provides the rationale and context for each step in the process. Each chapter also provides an overview of the information required to complete the section, examples and data entry tips for each step in the process, and a description of the automated operations of the data management system. The Appendices provide overviews of remote databases accessed by the data management system. 
Section 4. Relevance of the CAP to the Fish and Wildlife Service
In 1986, the FWS issued a preliminary survey of contaminant issues on NWRs, commonly known as the "Salmon Report". This report provided the first iteration of what was known about contaminant "issues of concern" throughout the National Wildlife Refuge System. It identified 78 issues on 85 refuges. Report findings were based on a questionnaire approach that lacked comprehensive documentation. This eventually became the subject of a Government Accounting Office report that viewed the initial attempt at documenting potential or known problems as inadequate. As a result, the DEC, Division of Refuges, and the USGS/BRD (and its predecessors) developed what is now the CAP. In 1996, CAP was initiated online through the Internet via the World Wide Web. The application of CAP by DEC field personnel to refuges is funded through the Refuge Investigations Program. Currently, about $15 \%$ of the on-refuge investigations' budget is devoted to CAP annually.

The value of conducting a CAP on an individual refuge or unit is considerable and can offer diverse benefits to the FWS. The National Wildlife Refuge System is a critical element of the Nation's attempt to provide for the conservation of biological resources through direct land and water management activities. Determining the optimum management strategy, as well as assessing the health of the system, by definition, requires that contaminant issues be appropriately documented and addressed. The CAP can provide valuable input to the Comprehensive Conservation Planning (CCP) process as mandated by the National Wildlife Refuge System Improvement Act of 1997. Information generated through the consistent application of the CAP will help the FWS better manage the National Wildlife Refuge System and its associated natural resources for the benefit of the American people. The CAP permits the retrospective analysis of existing information to determine the presence or absence of contaminant threats in a comprehensive, fully documented format. These data will support FWS's ability to prioritize actions and decisions. The CAP will support the FWS's ability to make the following actions/decisions:

(1) prioritize investigations that focus on potentially contaminated areas (PCAs);

(2) develop proposals to address common problems across refuges and regions;

(3) initiate pollution prevention activities directly or in partnership with others;

(4) initiate small cleanup actions or pre-assessment screens for natural resource damage assessments and acquisition; 
(5) provide rapid and credible responses to short time-frame requests for information on refuge status by eliminating "cold start" attempts to fill data needs, including automated reports from the CAP database; and

(6) foster complimentary use of CAP results in other activities such as refuge Comprehensive Conservation Plan development, pre-acquisition surveys, and interagency cooperation in research, monitoring, investigations, and management.

Finally, findings from the CAP result in and support actionoriented management decisions, document data gaps, and prioritize information needs. Actions taken as a result of completed CAPs can be documented to determine a number of performance measures that will help the FWS meet its strategic mission goals and objectives. These can be highlighted by reporting long-term and annual results under the Government Performance and Results Act. 
Chapter 2. Data Mianagement Syitem
This chapter provides an overview of the organization and operation of the data management system. It provides instructions for accessing the system, starting new files, reviewing, and editing information contained in the system. Contact information is provided for users who have questions regarding the CAP approach, suggestions for improving the process, or technical questions regarding the system.

Information for the CAP is administered with an Internet-based, data management system. The system, developed with joint funding from FWS/DEC and the BEST Program, resides on servers located at the Midcontinent Ecological Science Center (MESC) in Fort Collins, Colorado. A customized computer program coordinates the operation of software and hardware components that make up the system. The components of the system work together to manage user-entered information, store and manipulate tabular and spatial data, and control information retrieval from remote sources (i.e., EPA databases) via the Internet. Users access the system over the Internet using browser software operating on their personal computers. A password is necessary to use the system.

The configuration of the system provides a number of benefits to the user and FWS. The features of the system streamline the data entry process, eliminate redundant data entry, and support spatial and tabular outputs. Through its Internet links, the system facilitates access to five contaminant-source databases which are part of EPAs "Envirofacts Data Warehouse." In addition, the system retrieves administrative and ecological information from the FWS's Refuge Management Information System (RMIS) and the Contaminant Information Management and Analysis System (CIMAS). The RMIS database contains administrative and management information for units of the National Wildlife Refuge System. The system is maintained by the Division of Refuges and currently uses Filemaker Pro database software. Information in RMIS is organized into 7 modules including administration, education and recreation, oil/gas/mineral operations, maintenance, accomplishments, refuge goals/objectives and operational needs.

The CAP data management system's Internet retrieval capability reduces on-site data storage requirements and ensures that users have access to current information. Central administration of CAP information facilitates institutional memory and accessibility across organizational levels.

Information for CAP is hierarchically organized. A CAP refuge file contains all the records associated with the assessment performed on a refuge. The records, in turn, contain a series of fields appropriate to the information section or subsection. 
Section 2. Accessing the Data Management System and Data Entry Process Overview

\section{Getting a Password}

Accessing the Internet CAP Data Management System
Completing the CAP requires entering and reviewing information in 10 sections. Each section contains one or more subsections and each subsection has one or more data entry screen. Each data entry screen is composed of a series of fields. All data entry or editing takes place at the field level on individual data entry screens. Figure 2-1 provides an overview of the sections, subsections, data entry screens, and records that make up the CAP data management system. Sections 1 (Primary Contact) and 10 (Narrative Report of Contaminant Concerns) have only one data entry screen. Some sections have multiple data entry screens while others have a fixed number.

To enter, edit, or view information in the CAP data management system, users must obtain authorization from the DEC point of contact for CAP. Currently, the point of contact is Craig Moore. Craig can be reached at (703) 358-2148 or via e-mail at "Craig_R_Moore@FWS.gov". After receiving the request, the DEC point of contact will notify the CAP system administrators to issue a username and password to the authorized personnel. Due to Internet security considerations, the authorized user is typically provided with a username and password via a telephone call from the system administrators. After notification from DEC, system administrators issue usernames and passwords to authorized personnel.

The general steps involved in initiating a CAP data entry session are summarized below:

1. Start browser software and establish an Internet connection.

2. Type in the following Universal Reference Locator (URL) in the browser's address window:

\section{https://ecos.fws.gov}

3. Scroll down the page and select "CAP" by clicking the left mouse button.

4. A security dialog box is presented. Type in the authorized username and password:

Note: Use only lower case letters when entering the authorized usemame and password.

5. CAP files are organized according to FWS administrative regions. Note: A security feature limits a users' access to view or edit CAP files for refuges within their own administrative region.

The data management system facilitates the CAP by uploading information from two FWS data sources: RMIS, CIMAS, and five EPA databases, which include: 
Starting a New CAP File

Areas of Interest
- Toxic Release Inventory System (TRIS)

- Resource Conservation and Recovery Information System (RCRIS)

- Permit Compliance System/National Pollutant Discharge Elimination System (PCS/NPDES)

- Comprehensive Environmental Response, Compensation, and Liability Information System (CERCLIS)

- Aerometric Information Retrieval System (AIRS) Facility

By following the steps outlined below, the user initiates a process by which pertinent data are uploaded into the data management system. Information from RMIS and CIMAS is available immediately. Information from the EPA databases typically take 24 hours to upload into the CAP file. The user is able to enter information in other portions of the system while the upload is underway.

To start a new CAP file, scroll down the refuge selection screen and select the button labeled "Start New Study". The refuge selection screen presents two access options. The first option is titled "States/ Territories in Region ( $\mathbf{x}$ ") where $\mathbf{x}$ is the administrative region where the user is located. The second access option is titled "Refuges in Region (x)" and contains an alphabetical list of refuges in the users' administrative region.

Option 1: In this option, the user can select the state or territory of interest from the displayed list by clicking on it. This will display a directory of FWS-managed lands located in the selected state or territory. Select a specific refuge from this directory by clicking on it.

Option 2: In this option, the user can select from an alphabetical directory of FWS-managed units located in the administrative region. Scroll through the directory and select the FWS unit of interest.

Once the selection is made, the user is presented with a screen titled "Start New Assessment." On this screen, the user chooses from three data upload options, "Upload all," "Upload part," or "Upload data from a completed study into a new study."

Selecting one of the previous options sets the area of interest (AOI) for the assessment. In addition, it initiates an automated program that uploads refuge data from RMIS and CIMAS and contaminant information from the five EPA databases into the data management system. This is an important step in the process. The decision made at this point will dramatically affect the scope and 
complexity of the assessment. Before proceeding, the following information on AOIs and their relation to the process should be reviewed.

Environmental contaminants enter the environment as solids, liquids, gases, or mixtures. Once in the environment, they interact chemically with an array of biotic and abiotic media. Long- and shortrange transport of contaminant-associated media is primarily controlled by physical mechanisms. An underlying assumption of the CAP is that contaminants, in association with environmental media, tend to move along, more or less, predictable routes. The CAP approach categorizes the transport mechanisms by which contaminants move into three major types: surface water, ground water, and air. In addition, it identifies a fourth type, biotic transport, to account for contaminants that may be transported in the tissues by mobile biota.

Establishing the AOIs for each transport mechanism is a critical step in the CAP approach. Defining the extent of the AOI helps focus the assessment on those contaminant sources and types that are the most likely to reach the refuge by the transport mechanism. Once the AOIs are established, individual transport pathways are identified. Contaminant transport pathways are identifiable avenues within a transport mechanism through which the bulk of transported contaminants move. Finally, contaminant sources and types along each pathway are evaluated.

The data management system is programmed to automatically geo-reference the refuge and identify the hydrologic unit in which it is located. It then defines the AOI for the surface water, ground water, and air transport mechanisms and uploads data from EPA databases. Because the biotic transport mechanism is not usually directly linked to local contaminant sources, the system does not define an AOI for biotic transport or upload data from EPA databases.

The default AOIs for surface water and ground water correspond to the boundary of the watershed in which the refuge is located. The AOI for surface and ground water is defined by an 8-digit hydrologic unit code (HUC). The HUC system is a hierarchical, nationallyuniform, hydrological mapping framework developed by the USGS to map watershed boundaries. The default AOI for air is a $150 \mathrm{~km}$ buffer extending from the boundary of the refuge.

Upload All

Unless refuge-specific information that would warrant modifying the default AOI boundaries exists, the user should select the "Upload All" option to initiate a CAP study. This option uploads information from CIMAS, RMIS and source information from the five EPA databases for each default AOI into the data management system. 
Upload Part
To select this option, place the cursor on the button and click the left mouse button.

The "Upload part" option also uploads data for the FWSmanaged unit from RMIS and CIMAS. Unlike the "Upload all" option, it provides an opportunity for the user to upload information from EPA databases for areas other than the default AOI described above. This option allows the Primary Investigator to confine the assessment to a smaller AOI (sub-basin or reduced diameter of the air AOI) so that priority can be given to the contaminant sources and pathways most likely to affect the FWS-managed unit. For example, uploading contaminant source information for large, low-gradient watersheds or estuaries/coastal areas can generate an extensive set of facilities to review. While the potential contribution of all contaminant sources within the entire watershed is desirable, a comprehensive identification of contaminant sources may be unmanageable.

In some instances, the decision to reduce the default AOI may be fairly obvious (e.g., lands along the Mississippi River). However, in other cases, the potential difficulties of working with data from the default AOIs will be less apparent. The extent of the AOI must be based on professional judgement and determined on a case-by-case basis. It should be kept in mind that the reason for reducing the default AOI is to focus efforts on the contaminants most likely to be causing problems and ensure that the contaminant assessment process can be conducted efficiently. Therefore, a decision to reduce an AOI should not be based solely on the size of the watershed/AOI, but on the probability that contaminant sources are contributing significantly to environmental conditions on the FWS-managed unit.

In the case of very large refuges, it may be necessary to divide the unit into manageable sections and perform individual assessments for each parcel. This approach may reduce the number of sources and pathways to a manageable scale and provide managers with a more concise summary of potential contaminant issues. For example, individual assessments could be conducted on each management unit, HUC, or sub-basin within the refuge boundary.

Once the decision to upload data for a modified AOI is made, the user must provide a written description of the extent of the desired area. That description should be entered into the text box associated with the "Upload part" option. After the description is entered, the upload is initiated by clicking the "Upload part" button. This action notifies the system's administrators to modify the extent of area for which a query will be submitted to the EPA databases. It is advisable to contact the Help Desk after selecting this option to clarify the request (see Section 3 of this Chapter for contact information). 
Upload Data from a Completed Study into a New Study

\section{Reviewing and Editing}

On-going and Completed CAP Studies

Copying and Pasting Information into the Data Management System
Occasionally, multiple FWS units are managed as a complex. In such cases, a good deal of the information required to complete the CAP for individual units located within the complex may be similar. Types of information overlapping within a complex may include the name of the Primary Investigator, management objectives, habitat types, land uses, and local off-FWS lands important to trust resources. This option allows a user to upload data from a completed study into a new study, thereby eliminating the need to reenter redundant information. While this option is potentially a time-saving approach, it should be used with caution. For example, even though units are proximal to one another, they may not necessarily share common transport pathways. In some cases, management objectives for units within a complex may differ. It is strongly recommended that the user review all of the uploaded information to ensure that it is applicable to the new unit.

To select this option, scroll down the list of FWS-managed units presented in the menu and select the study of interest. Once the study is highlighted, select the button labeled "Copy selected data set" and click the left mouse button. Information not applicable to the current assessment can be deleted at the record level.

After a new CAP study is initiated, the data management system adds the name of the refuge to the list of on-going studies in the region. The user begins subsequent CAP data entry sessions by opening the file. To open an existing file, access the data management system. The system displays a menu organized under two headings, "On-going Studies in Region x," and "Completed Studies in Region $x$." The list of CAP files presented under "Completed Studies in Region (x)" includes those files for which the data entry and analysis process have been finished. To review or edit on-going or completed studies, select the file of interest from the appropriate list by clicking on it. Executing this step opens the "Main Menu" for the selected refuge and allows the user to initiate the data entry process.

Information in format can generally be copied from one application (i.e., ASCI, HTML, various word processing software), and pasted directly into the data management system. To block text, highlight it. The highlighted text can be copied by using the software defined key, or by pressing the keys "Ctrl" and "C" simultaneously. To paste the information, toggle to the data management system, place the cursor in the field of interest and press the keys " $\mathrm{Ctrl}$ " and "V" simultaneously. By using this approach, lengthy text entries can be drafted using word processing software (as in Section 10, Narrative Report of Findings) edited, spell-checked, and then pasted into the data management system. This approach will generally not 
Section 3. Technical Support

Connectivity and Browser Compatibility Questions

Instructional/Orientation Questions

Technical Questions or Difficulties Using the Data Management System copy formatting commands (i.e., italics, tabs, indents, or bold letters) but will eliminate the need to manually rekey existing information into the data management system. Carriage returns should be used to separate paragraphs in longer entries.

Specialists using the data management system are likely to have questions or encounter problems that require technical assistance. This section of the chapter provides information for contacting the appropriate individuals to resolve them. Beyond obtaining a password, these questions or problems will fall into six categories:

(1) connectivity or browser compatibility questions

(2) instructional/orientation questions

(3) technical questions or difficulties using the data management system

(4) interpretive/process questions

(5) recommendations for improving the process or the data management system

Users with questions about establishing and maintaining Internet connection to the data management system should contact their local information resource management staff or local area network administrators. These types of questions are site-specific and cannot be addressed by MESC technical support staff. Questions concerning the compatibility of the users' browser software to the data management system should be addressed by MESC technical support staff.

Individuals needing instructions on accessing and navigating the data management system should first review the online guidance and context-sensitive help that is accessible for each data input screen. After these resources have been explored, if the user still needs help with the data system, they should contact MESC system administrators for technical support. The Help Desk can be reached by calling MESC support staff in Fort Collins, Colorado at (970) 226-9372 between 9 A.M. to 4 P.M. (Mountain Time), Monday through Friday. Periodically, DEC will provide online teleconference training sessions. These sessions are intended primarily for new users, those needing refresher instructions, or whenever major changes are made to the system. These training sessions will be announced and scheduled to meet users' needs and schedules.

The data management system resides on servers located at MESC. The system was developed and is administered by staff of the Technology Applications Team. Users experiencing technical 


\section{Interpretive/Process Questions}

\author{
Section 4. Periodic \\ Modifications \\ of the CAP Data \\ Management System
}

Overview

\author{
Recommendations for \\ Improving the Process or \\ the Data Management System
}

difficulties with the system (i.e., program bugs, access to the system, lost or misplaced data) should contact the MESC Help Desk (see number and hours in previous section).

Users with interpretive questions about the CAP itself should discuss the matter with Craig Moore, who currently is the primary CAP point of contact. Craig can be reached at DEC, R-9 Headquarters, Arlington, Virginia at (703) 358-2148 or via e-mail at “Craig_R_Moore@FWS.gov".

The CAP and its supporting data management system will undergo periodic refinements. As currently anticipated, changes to the data management system will occur about every 2 years. Between these modifications, the configuration and operation of the data management system will remain consistent. Alterations to the approach or data management system will be made through a structured process to minimize confusion. The process will involve collecting user's feedback and prioritizing the suggested enhancements. DEC Region 9 will be responsible for administrative coordination to initiate any programming changes required to effect the modifications. All new programming will be conducted on a developmental server and will not affect the operation of the current online system. All modifications will undergo thorough testing and review. Modifications will be announced and orientation to the operation of the system will be provided before they are put in effect.

To provide a forum for obtaining user feedback, DEC formed a joint CAP/CIMAS users' group, consisting of regional and headquarters representatives, to provide input for modifying the CAP data management system. Users with recommendations for improving the process or the data management system should communicate their ideas to their regional representative serving on the CAP/CIMAS users' group. Alternatively, suggestions for improvement can be made directly to the DEC point of contact for CAP (currently Craig Moore who can be reached at (703) 358-2148 or via e-mail “Craig_R_Moore@FWS.gov"). Implementation of recommended modifications will be jointly coordinated through DEC and the CAP/CIMAS users' group. 


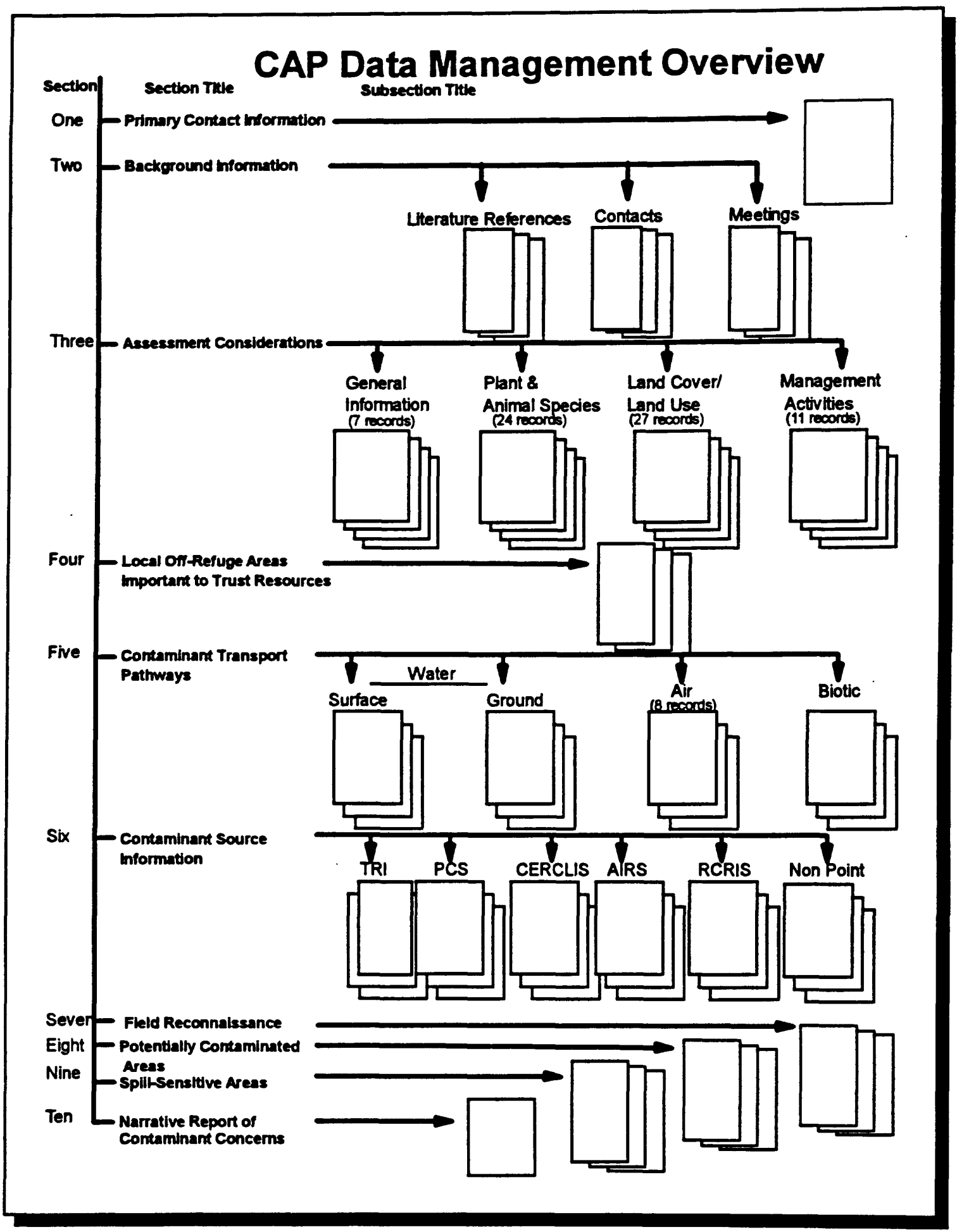

Figure 2-1. CAP data management overview. 
Clappter 3. Erecuting the contaminab: Assessment Process

\section{Section 1. Getting Started}

Area Familiarization

Familiarization with the Data Management System

Integrating Local Expertise
This chapter is intended to help the Primary Investigator prepare for and execute the CAP. It provides recommendations to assist contaminant specialists, refuge biologists, and other FWS personnel in collecting the necessary information for completing the CAP. In addition, this chapter contains an example memo that may be used by the specialist to arrange an interview with refuge staff to initiate and explain the purpose of the CAP. The suggestions contained in this chapter reflect recommendations from a number of contaminant specialists who have been involved with applying the CAP on various national wildlife refuges.

Prior to starting any work in the CAP data system or conducting field investigations, specialists should familiarize themselves with the refuge by studying map products and other pertinent background materials. For example, maps developed by federal and state Departments of Transportation, National Wetland Inventory, and USGS topographic maps can provide valuable insight regarding the locations of transportation corridors, land cover, and surface characteristics that may influence the movement of contaminants. The Primary Investigator should check the accuracy of the refuge's boundaries on all maps as inaccurate or outdated information may influence conclusions regarding potential sources, pathways, and likelihood of exposures. In reviewing these materials, the Primary Investigator should try to identify significant surface water pathways that reach the refuge. Where possible, the direction of ground water flow should be determined. The Primary Investigator should evaluate the proximity of the refuge to metropolitan, industrial, agricultural, and recreational areas. An analysis should be made of pipelines, utility lines, railroads, highways, or other transportation routes that cross the boundaries of the refuge or are close to the unit.

Prior to working on the CAP, it is recommended that users review this document and familiarize themselves with the data management system. The system allows users to review completed CAPs within their region. The user should review the various sections that comprise the system, particularly the order in which the sections are arranged. While information can be entered out of sequence, some fields are linked to more than one section. Data entry for the CAP is intended to be completed in a sequential manner.

The CAP is intended to be completed by a team consisting of refuge staff and a contaminant specialist. Establishing a good working relationship with the refuge manager and other refuge personnel will facilitate the Primary Investigators' ability to gather the necessary 
information. It is highly recommended that the Primary Investigator arrange an interview with refuge staff to encourage the sharing of pertinent information.

The following attachment contains an example memo to the refuge manager that explains the purpose of the CAP and explains the need for a meeting with refuge staff. It also contains suggested questions that will help refuge staff prepare for the interview and may help reveal critical information during the interview. An interview with refuge staff is likely to reveal other sources of valuable, local information. For example, refuge staff may be able to direct the Primary Investigator to individuals or organizations with local expertise, such as state/local fish and game authorities, state and local EPA staff, state and local energy commissions, and local colleges or universities. In addition, it is recommended that the National Weather Service be contacted (in person or via the Internet) to determine seasonal weather trends, wind speeds, and wind directions for the area encompassing the refuge. Literature references from peer-reviewed journals and "grey" literature sources should also be gathered. Potentially valuable information for the refuge may also be found in the Refuge Narrative Reports, Station Management Plans, Master Plans, and Ecological Impact Statements. Appendix A consists of a checklist of information sources that should be reviewed as part of the retrospective analysis. 


\section{Attachment \\ Example Memo to Refuge Manager}

\section{MEMORANDUM}

To: $\quad$ Refuge Manager

From: Environmental Contaminant Specialist

Subject: Contaminant Assessment Process

The U.S. Fish and Wildlife Service Division of Environmental Contaminants and Division of Refuges, in conjunction with the U.S. Geological Survey's Biomonitoring of Environmental Status and Trends Program, has developed and refined a systematic, cost-effective process for evaluating whether environmental contaminants pose threats to lands or biota managed by bureaus of the Department of the Interior (DOI), including National Wildlife Refuges. The Contaminant Assessment Process (CAP) consists of two parts: retrospective analysis (involving a review of existing information) and field-sampling. The final product is a comprehensive contaminant, geophysical, and land use profile of the unit. The CAP provides information to help FWS decision makers identify significant contaminant issues, prioritize contaminant investigations, and select remediation alternatives.

The process involves interviewing knowledgeable staff and individuals with local expertise to obtain information contributing to a more complete understanding of local contaminant concerns and resource issues. Field reconnaissance is conducted to develop a better understanding of refuge characteristics and evaluate potentially contaminated areas. Biogeographic and contaminant source information is acquired from various agency and interagency databases. Relevant information is compiled, reviewed, and entered into the CAP data management system. This information will help biologists and resource managers improve their understanding of local contaminant issues and contribute to developing resource management plans.

An important part of the process involves conducting interviews with refuge staff. After receiving this memo, I will be calling you to schedule a meeting to interview you and/or your staff. In preparation for the interview, please review the attached material and identify refuge information sources that may pertain to the topics that we will be discussing. In general, the questions are arranged according to the following topics:

1. Known or Suspected Contaminant Issues

2. Off-Refuge Areas Important to Trust Resources

3. Potential Contaminant Transport Pathways

4. Observed Mortality Incidents

5. Public Meetings on Contaminant Issues

6. Local Experts

7. Literature Sources

8. Refuge Characteristics/Management Activities

9. Species Lists

Thank you in advance for your assistance in this matter. I look forward to our meeting, and please call me if you have any questions or wish to further discuss this matter. 


\section{Attachment (continued) \\ List of Questions}

1. Known or Suspected Contaminant Issues

- What potentially and/or previously identified contaminated sites exist on lands under your stewardship/supervision?

- Have any of the following historical land uses occurred on or near the refuge that might convey contaminants to the unit by surface or ground water flow (including areas that may be hydrologically connected by dry washes, arroyos, springs, wells, etc.)?

* sewage treatment plants

* ranching

* farming or agricultural processing plants

* feedlots

* logging

* mining

* industry

* refuse dumping/burning

* wrecking yards

* military sites (i.e., radar installations, motor pool, exploded/unexploded munitions)

* railroad tracks, depots

- Are there historic or current locations which may be associated with contaminant issues, for example:

* tailing piles

* dump sites (for trash, motor oils, chemicals, etc.), pesticide/herbicide/chemical and fuel storage lockers/tanks

* industrial or other processing centers

* incinerators

* shooting ranges

* agricultural fields

* silage bins/piles

* vehicle and aircraft parking/storage, fueling, or maintenance areas

* electrical transformers and power generating stations

* irrigation or ground water/well pumps

- sites that might have had spills, concentrations of contaminants, or other areas of concern

* cattle dip tanks or farm equipment spray stations

- Are there any current or historic drinking/well water or consumption advisories issued on or near refuge lands? If so, how deep are your wells?

- Are there known or suspected site(s) on or near the refuge that might require clean-up or remediation to remove contaminants?

- Have refuge staff responded to a hazardous waste spill on-or off-refuge (when and where)? 


\section{Attachment (continued) \\ List of Questions}

- If any suspected or known contaminated sites occur on government land, are the appropriate managing officials aware of the situations?

- Have you ever observed oil sheens or other signs of pollution on the refuge?

- Do state or county vector control agents spray pesticides on or adjacent to the refuge?

- If any suspected or known contaminated sites occur on private lands near the refuge, does the refuge maintain the phone numbers or means to contact the affected landowner or manager?

- Are there documented or suspected contaminant concerns that may relate directly to the biodiversity found on the refuge, the ability to meet refuge management objectives, or that may impact protected species found on the refuge?

\section{Local Off-Refuge Areas Important to Trust Resources}

- Are there local off-refuge areas that are important to trust resources? For example, areas that provide:

* food/water resources

* shelter/nesting to species using the refuge (if possible, provide geographic coordinates)

3. Potential Contaminant Transport Pathways

- What are the primary surface water (rivers, creeks, washes, irrigation ditches ) and ground water pathways (springs, wells) located on or that traverse the refuge or which might serve to facilitate the movement of contaminants onto or within the unit?

- What are the local predominant wind directions?

- Are there significant seasonal variations in the predominant wind directions?

- Do refuge lands support large numbers of migratory wildlife, domesticated animals, or abundant populations of invertebrates? Are they treated for biting insects? If so, with what and when?

- Are livestock imported to this area from other locations (i.e., cities, counties, states, countries)?

- Are there any significant corridors on or near the unit (highways, railroads, canals, shipping lanes, pipelines) on which potentially hazardous materials are transported? 


\section{Attachment (continued) List of Questions}

\section{Observed Die-Offs}

- Have there been large-scale illnesses or die-offs of fish, wildlife, or domestic animals in the area? If so, when and where? If so, to what were the die-offs attributed?

- Have there been any instances of deformities, unusual sickness, or unsuccessful breeding in wildlife, plants, or domestic animals in the area? If so, when and where?

\section{Public Meetings}

- Have any environmental and/or human health organizations held public meetings on contaminant issues that may be affecting the unit? If so, who are the main contacts? May we schedule a phone call or appointment with them on the day(s) of my visit? Do they have literature available?

\section{Local Experts}

- Are there knowledgeable staff, local experts, previous landowners, or current neighboring landowners who may have information that might contribute to a better understanding of local contaminant issues potentially affecting the refuge? Would it be possible to contact them during the upcoming interview?

- Are there any state, federal, or non-governmental organizations that might have detailed records of land use and management activities in this area?

\section{Literature Sources}

- Does the refuge maintain an on-site library of references, findings from studies, or reports pertaining to pollution, contaminants, human and environmental health, or issues that may be affecting the unit? Is the material maintained at the refuge indexed?

- Do the refuge's annual reports contain information on old spill events, die-offs, or local contaminant issues?

\section{Refuge Characteristics/Management Activities}

- Are there any management activities on the refuge that may be significant to contaminant issues?

- Are there any ongoing research or monitoring activities related to contaminant issues on the' refuge?

- Have baseline or reference sampling locations been identified on the refuge?

- Does the refuge engage in agriculture, silviculture, or aquaculture practices that might directly or indirectly contribute contaminants (pesticides, nutrients, erosion) to the unit? 


\section{Attachment (concluded) \\ List of Questions}

- Are there any particularly sensitive areas on the unit that might be adversely affected in the event of a contaminant release from contaminated sources on or near the refuge (i.e., nesting sites, wetlands, etc.)?

\section{Species Lists/Land Use}

- Does the refuge maintain plant and animal species lists? If so, can they be available for the interview?

- Has the refuge quantified land cover/use patterns?

- Are there detailed historic and current maps available for the refuge? 


\section{PART II: GUIDANCE FOR COMPLETING CAP AND DATA ENTRY}


Chapter 1. Primins:

investigator:

Section 1. Overview

Section 2. Data

Management System Operation
Section 1 of the data management system is to record information about the Primary Investigator, who is responsible for the content and findings of the contaminant assessment. The information documented in this section provides a point of contact for those who may have questions concerning the information or findings contained in this file. While portions of the information in the assessment may be provided by others (assistant contaminant specialists, refuge staff) the person identified in this section is responsible for quality-assuring the information and justifying the findings contained in this file. The CAP will be periodically repeated. The name of the Primary Investigator conducting earlier assessments should be recorded in the "Background Information - Contacts" section of the most recent CAP file.

The information required for this section is recorded on a single record. The data management system provides no direct links between this information and other sections. 


\section{Section 3. Guidance for Data Entry and Analysis: Primary Investigator}

Table 1-1. Field description and examples: Primary Investigator.

\begin{tabular}{l|l|l}
\hline Field Name & \multicolumn{1}{|c|}{ Content Guidance/Erample } & Data Entry Tips \\
\hline First name & $\begin{array}{l}\text { Surname and title (if appropriate) of person primarily responsible for } \\
\text { information in record. Example: Susan. }\end{array}$ & Character limit: 40 \\
\hline Last name & $\begin{array}{l}\text { Last name of person primarily responsible for information in record. } \\
\text { Example: Blackford. }\end{array}$ & Character limit: 40 \\
\hline Street address & $\begin{array}{l}\text { Street address where primary contact can be reached. } \\
\text { Example: 315 Houston, Suite 3. }\end{array}$ & Character limit: 80 \\
\hline City, state, zip & $\begin{array}{l}\text { City, state, and zip code where primary contact can be reached. } \\
\text { Example: Manhattan, KS 66502. }\end{array}$ & Character limit: 80 \\
\hline Phone number & $\begin{array}{l}\text { Phone. number, including area code (and extension if needed) where } \\
\text { primary contact can be reached. Example: 785-539-3474 r11. }\end{array}$ & Character limit: 20 \\
\hline e-mail & $\begin{array}{l}\text { Complete alpha-numeric e-mail address for primary contact. } \\
\text { Example: Susan Blackford@,FWS.GOV. }\end{array}$ & Character limit: 60 \\
\hline Fax & $\begin{array}{l}\text { FAX number, including area code where primary contact can be reached. } \\
\text { Example: 785-539-8567. }\end{array}$ & Character limit: 20 \\
\hline Affiliation & $\begin{array}{l}\text { Organization (including field office name, if appropriate) the Primary } \\
\text { Investigator is affiliated with. Example: U.S. Fish and Wildlife Service. }\end{array}$ & Character limit: 50 \\
\hline $\begin{array}{l}\text { Notes on } \\
\text { Primary } \\
\text { Investigator }\end{array}$ & $\begin{array}{l}\text { Identify all individuals who assisted the Primary Investigator (i.e., } \\
\text { collating, entering or interpreting information), including names of refuge } \\
\text { staff or staff from other agencies. Example: Assistant Contaminant } \\
\text { Specialist, Ecological Services, Kansas Field Office. }\end{array}$ & $\begin{array}{l}\text { Character limit: } \\
\text { 2,000. Field cannot } \\
\text { be printed }\end{array}$ \\
\hline
\end{tabular}


Section 1 - Prinary Investigator Information

KTwon NWR

Frat Em Surean

Lart mone Bleckeford

street Address: 315 Mouseon, so1te E

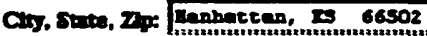

Pheae Nember 705-539-3974 $\times 11$

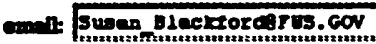

FAT: $785-539-8567$

A.rition: 0.8. T10h 6 Tildilfe Service

Noces on Prtanery Investipator

Laniotane Contminant Specialist, Zeological Services, fo

raboen Field Ozfice.

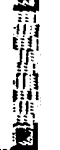

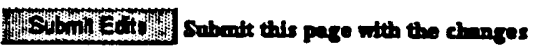

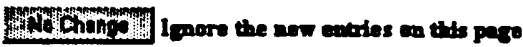

Min Meon

Help

Figure 1-1. Data entry screen: Primary Investigator. 
Q6apter. 340 iground Intonmation

Section 1. Overview

\author{
Section 2. Data \\ Management System \\ Operation
}

Section 2 of the data management system is used to document existing background information that will help the investigator better understand local contaminant issues and the biological resources that could be impacted by these contaminant threats. The purpose of this section is to gather information from peer-reviewed journals and grey literature. It will also serve to document the names, affiliations, and contact information for individuals with expertise in the local area and summarize the outcomes from meetings held to discuss issues involving environmental contaminants. Information on point and nonpoint contaminant sources is documented later in the process. If no information is to be entered in a subsection, document this in the "Notes" field on the record selection menu for the section (i.e., if no meetings were conducted).

There are three subsections of information in this section: literature references, contacts, and meeting information.

An unlimited number of records can be entered for each subsection. The data management system does not return information from other databases. The names of contacts entered in this section are displayed in a picklist for each record in Section 2: Background Information - Meetings; Section 4: Local Off-Interior Lands Important to Trust Resources; Section 6: Contaminant Source Information; and Section 7: Field Reconnaissance. 
Section 3. Guidance for Data Entry and Analysis: Literature References
The literature reviewed should include documents authored by federal, state, educational institutions, and local environmental agencies. Focus should be placed on documenting contaminant sources, pathways, and receptors. The following list provides examples of the types of citations that may be relevant to the contaminant assessment.

- refuge narrative reports

- die-offs, deformities, population declines, and suspected causes

- known contaminant sources and released clean-up activities for species affected, (i.e., oil spills, pesticide over-spray events)

- reports or results from previous research, surveys, and compliance monitoring efforts

- descriptions of sensitive habitats/communities

- notable changes in physical conditions (i.e., droughts, floods, eutrophication, sedimentation, water quality)

- planning documents describing activities for refuges that could potentially contribute to contamination problems (livestock, weed eradication, pesticide use, water management, recreation)

- documentation supporting selection of potential reference site locations or data

- federal, state, and local regulations that require periodic data collection or monitoring

- comprehensive conservation plans 
CAP USER's GUIDE 
Table 2-1. Field descriptions and examples: Background Information'- Literature References.

\begin{tabular}{|c|c|c|}
\hline Field Name & Content Guidance/Example & Data Entry Tips \\
\hline Title & $\begin{array}{l}\text { Document citations which may support a better understanding } \\
\text { of contaminant issues affecting the refuge. Erample: Planning } \\
\text { Aid Report: Instream Flow and Analysis-Solomon River } \\
\text { Basin, KS. }\end{array}$ & $\begin{array}{l}\text { Character limit: } 80 \\
\text { "\#” or “"!" not allowed }\end{array}$ \\
\hline $\begin{array}{l}\text { Reference } \\
\text { citation }\end{array}$ & $\begin{array}{l}\text { Provide the full citation for the journal article or report that is } \\
\text { being referenced. Example: U.S. Fish and Wildlife Service. } \\
\text { 1993. Planning Aid Report: Instream Flow and Stream } \\
\text { Analyses of the Solomon River Basin, Kansas. USFWS } \\
\text { unpublished report. }\end{array}$ & Character limit: 250 \\
\hline $\begin{array}{l}\text { Contaminant } \\
\text { sources } \\
\text { identified in } \\
\text { reference }\end{array}$ & $\begin{array}{l}\text { Document the types of contaminant sources (point and } \\
\text { nompoint) that are described in the reference. If the reference } \\
\text { does not describe a contaminant source, do not make a selection } \\
\text { from the picklist. Example: Other. }\end{array}$ & $\begin{array}{l}\text { Picklist: } 70 \text { selections. } \\
\text { Defaults to "Not } \\
\text { Applicable". Multiple } \\
\text { selections can be made. }\end{array}$ \\
\hline $\begin{array}{l}\text { Contaminant } \\
\text { categories } \\
\text { identified in } \\
\text { reference }\end{array}$ & $\begin{array}{l}\text { Document the contaminant categories that are described in the } \\
\text { reference. If the reference does not describe a contaminant } \\
\text { category, do not make a selection from the picklist. Example: } \\
\text { Water Quality Parameters. }\end{array}$ & $\begin{array}{l}\text { Picklist: } 64 \text { selections. } \\
\text { Defaults to "Not } \\
\text { Applicable". Multiple } \\
\text { selections can be made. }\end{array}$ \\
\hline $\begin{array}{l}\text { Brief } \\
\text { description of } \\
\text { the information } \\
\text { in this reference }\end{array}$ & $\begin{array}{l}\text { Summarize the focus of the citation, if appropriate methods, } \\
\text { results, and conclusions/inferences were drawn by the } \\
\text { investigator. Species, habitats, contaminant sources, and types } \\
\text { evaluated in the reference should be identified. The abstract of } \\
\text { the citation can be entered here. Erample: Evaluation of } \\
\text { streams in the Solomon River basin to assess their } \\
\text { conditions, problems and needs. Instream flow } \\
\text { recommendations determined for the North Fork Solomon } \\
\text { River which flows into Kirwin Reservoir and Kirwin NWR. } \\
\text { Low flow is a substantial limiting factor affecting basin } \\
\text { streams. Sedimentation from nonpoint agricultural runoff } \\
\text { and bank erosion is also identified as a major himiting factor } \\
\text { for the North Fork Solomon River. }\end{array}$ & Character limit: 2,000 \\
\hline $\begin{array}{l}\text { Relevance of } \\
\text { reference to } \\
\text { assessment }\end{array}$ & $\begin{array}{l}\text { Explain how the information presented in the citation supports } \\
\text { a clearer understanding of contaminant issues at the refuge. } \\
\text { Example: Report identifies loss of flow and sedimentation as } \\
\text { the major limiting factors of habitat suitability for fish } \\
\text { species of the North Fork Solomon River feeds Kirwin } \\
\text { Reservoir and Kirwin NWR. }\end{array}$ & Character limit: 2,000 \\
\hline
\end{tabular}




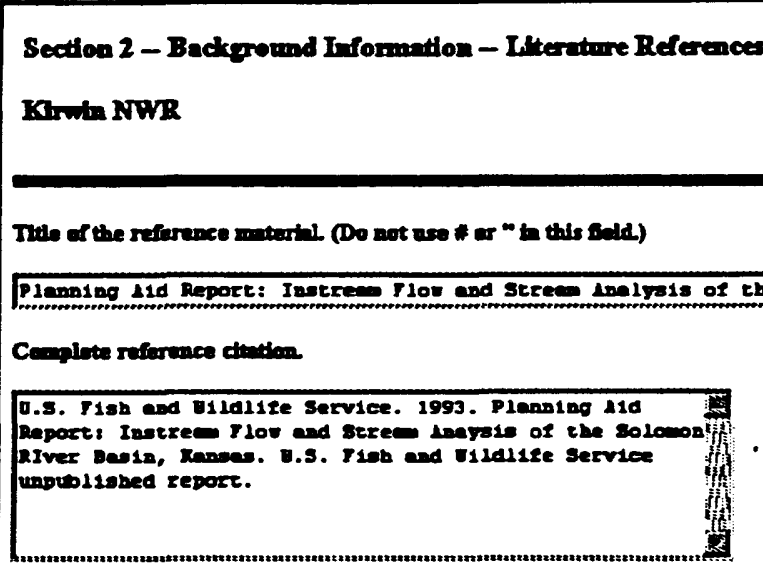

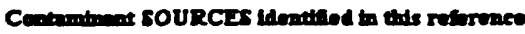

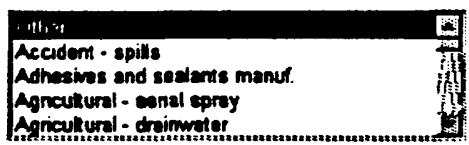

Certantumat CATECORJES Identined th this roforence

Nitoome Gaseous Pollutants
Aitome Perticuletes
Akalinity
Auminum

Briaf dosestption of the heforination in this raformes

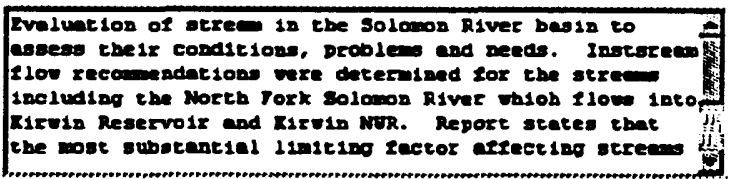

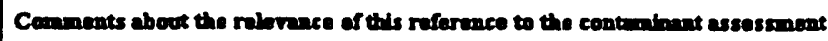

Report Ideatifies loss of rlov and sedimetat $10 \mathrm{n}$ as the d pajor liniting Iectors of bublet auicebility for Iish jij species of the Norch Tork Solomo River ebich Ilowe into Kifola Reservoli and Riruis Mr.

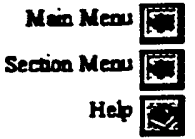

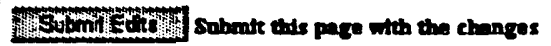

15.

Mosident Delete this recard

Figure 2-1. Data entry screen: Background Information - Literature References. 
Section 4. Guidance for Data Entry and Analysis: Contacts
Personal contacts may provide historic and current information that is not readily available from other sources. The types of contacts that should be documented as part of the assessment include people with contaminant, biological, hydrological, and management expertise. The following list provides examples of the types of experts that may provide valuable background information for the assessment.

- local and regional refuge management staff

- agricultural extension agents (knowledgeable on pesticide use)

- environmental engineers with responsibilities at industrial or municipal facilities

- conservation organization personnel

- state water and air quality authorities

- state and federal contacts with oversight responsibilities for Superfund sites

- local, state, or federal emergency response personnel

- irrigation district personnel

- local fish and game personnel

- local FWS law enforcement agents 
Table 2-2. Field descriptions and examples: Background Information - Contacts.

\begin{tabular}{|c|c|c|}
\hline Field Name & Content Guidance/Example & Data Entry Tips \\
\hline First name & Surname and title (if appropriate) of contact. Example: Bruce & Character limit: 40 \\
\hline Last name & Last name of contact. Example: Schoonover. & Character limit: 40 \\
\hline Street address & $\begin{array}{l}\text { Street address where contact can be reached. } \\
\text { Example: } \mathbf{4 2 3} \text { Hatchery Circle. }\end{array}$ & Character limit: 80 \\
\hline City, state, zip & $\begin{array}{l}\text { City, state, and zip code where contact can be reached. } \\
\text { Example: Spearfish, SD 57783-4643. }\end{array}$ & Character limit: 80 \\
\hline Phone number & $\begin{array}{l}\text { Phone number, including area code (and extension if needed) } \\
\text { where contact can be reached. Erample: 605-642-7730. }\end{array}$ & Character limit: 20 \\
\hline e-mail & $\begin{array}{l}\text { Complete alpha-numeric e-mail address for primary contact. } \\
\text { Example: bruce schoonover@mail.fws.gov. }\end{array}$ & Character limit: 60 \\
\hline Fax & $\begin{array}{l}\text { Fax number, including area code, where primary contact can be } \\
\text { reached. Erample: }(605) 642-7700 \text {. }\end{array}$ & Character limit: 20 \\
\hline Affiliation & $\begin{array}{l}\text { Organization (including field office name if appropriate) that the } \\
\text { primary contact is affiliated with. } \\
\text { Erample: USFWS Booth Historic National Fish Hatchery. }\end{array}$ & Character limit: 50 \\
\hline $\begin{array}{l}\text { Contaminant } \\
\text { sources linked } \\
\text { to contact }\end{array}$ & $\begin{array}{l}\text { Use this picklist to document the types of contaminant sources } \\
\text { (point and nonpoint) that are described in the reference. If the } \\
\text { reference does not describe a contaminant source, do not make a } \\
\text { selection from the picklist. Example: Other. }\end{array}$ & $\begin{array}{l}\text { Picklist: Up to } 70 \\
\text { selections. Defaults to } \\
\text { "Not Applicable". }\end{array}$ \\
\hline $\begin{array}{l}\text { Contaminant } \\
\text { categories } \\
\text { linked to } \\
\text { contact }\end{array}$ & $\begin{array}{l}\text { Use this picklist to document the contaminant categories that are } \\
\text { described in the reference. If the reference does not describe a } \\
\text { contaminant category, do not make a selection from the picklist. } \\
\text { Example: Water Quality Parameters. }\end{array}$ & $\begin{array}{l}\text { Picklist: Up to } 64 \\
\text { selections. Defaults to } \\
\text { "Not Applicable". }\end{array}$ \\
\hline $\begin{array}{l}\text { Brief } \\
\text { description of } \\
\text { this contact }\end{array}$ & $\begin{array}{l}\text { Summarize the contacts' expertise as it applies to the current } \\
\text { assessment. Provide a brief synopsis of the individuals' } \\
\text { knowledge base and the type of information that the contact } \\
\text { would likely be capable of providing. Example: Bruce was the } \\
\text { Refuge Manager for many years until 1996. He is now } \\
\text { stationed at the DC Booth Historic National Fish Hatchery. }\end{array}$ & Character limit: 2,000 \\
\hline $\begin{array}{l}\text { Relevance of } \\
\text { reference to } \\
\text { assessment }\end{array}$ & $\begin{array}{l}\text { Explain how the expertise of the contact could support a clearer } \\
\text { understanding of contaminant issues at the refuge. Example: } \\
\text { Historic information about Kirwin NWR. }\end{array}$ & Character limit: 2,000 \\
\hline
\end{tabular}




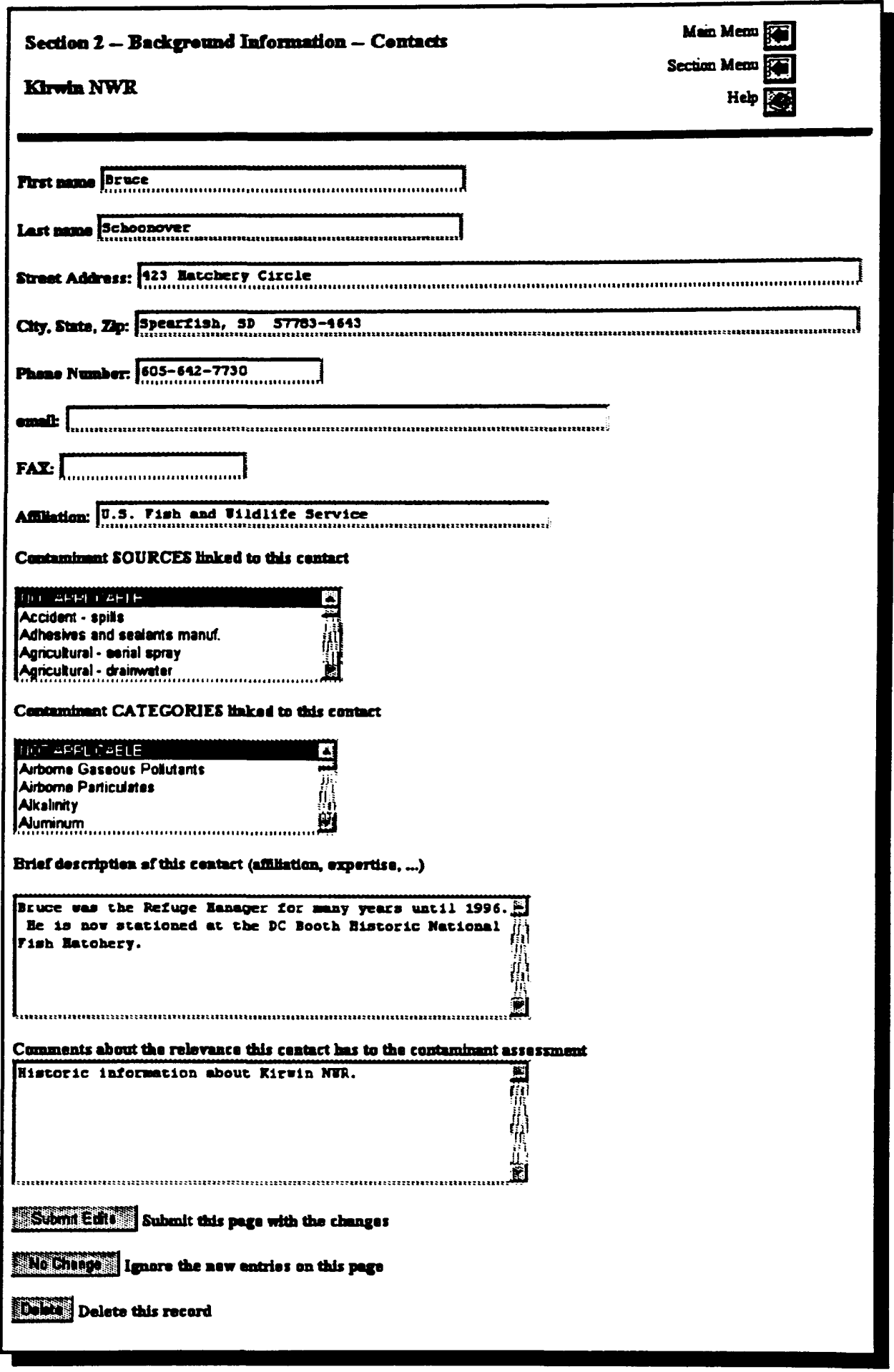

Figure 2-2. Data entry screen: Background Information - Contacts. 
Section 5. Guidance for Data Entry and Analysis: Meetings
Meetings where refuge-related contaminant issues are discussed should be described. In particular, recommendations and decisions coming out of the meetings should be documented. Some examples of meetings that should be described include:

- endangered species listing hearings

- meetings with conservation groups

- restoration planning meetings

- Coordination Act Activities (permit reviews)

- internal project coordination meetings

- NRDA or NEPA public meetings

- meetings relating to fish and wildlife management or concerns 
Table 2-3. Field descriptions and examples: Background Information - Meetings.

\begin{tabular}{l|l|l}
\hline Field Name & \multicolumn{1}{|c}{ Content Guidance/Example } & Data Entry Tips \\
\hline $\begin{array}{l}\text { Title/topic of } \\
\text { the meeting }\end{array}$ & $\begin{array}{l}\text { Give the complete title of the meeting. If the meeting was not } \\
\text { officially named, provide a descriptive meeting title. If no } \\
\text { meetings have been held, enter "No meeting information } \\
\text { available". Example: Public meeting to discuss ground water } \\
\text { contamination at Stuttgart Oil Company. }\end{array}$ & Character limit: 80 \\
\hline Meeting date & Provide the date(s) of the meeting. Example: April 12, 1997. & Character limit: 20 \\
\hline $\begin{array}{l}\text { Meeting } \\
\text { organizer(s) }\end{array}$ & $\begin{array}{l}\text { Review the picklist provided and select appropriate name. If the } \\
\text { name of the meeting organizer does not appear on the picklist, } \\
\text { enter the name of the organizer in the following fields. Example: } \\
\text { Susan Blackford. }\end{array}$ & $\begin{array}{l}\text { Picklist: Displays } \\
\text { names of contacts } \\
\text { previously entered in } \\
\text { Section 2. }\end{array}$ \\
\hline First name & $\begin{array}{l}\text { Surname and title (if appropriate) of contact. Example: Dr. } \\
\text { Fritz. }\end{array}$ & Character limit: 40 \\
\hline Last name & Last name of contact. Example: Knopf. & Character limit: 40 \\
\hline $\begin{array}{l}\text { Brief } \\
\text { description of } \\
\text { this meeting }\end{array}$ & $\begin{array}{l}\text { Summarize the purpose for the meeting, topics, and concerns } \\
\text { that were discussed, and decisions that were reached (if any). } \\
\text { Example: An informational meeting was sponsored by the } \\
\text { U.S. EPA to update local stakeholders on the status of efforts } \\
\text { to clean up carbon tetrachloride found in domestic wells near } \\
\text { the Stuttgart Oil Company. Ground water models were } \\
\text { discussed. }\end{array}$ & Character limit: 2,000 \\
\hline $\begin{array}{l}\text { Relevance this } \\
\text { meeting has to } \\
\text { the assessment }\end{array}$ & $\begin{array}{l}\text { Explain how the information developed through the meeting is } \\
\text { related to understanding contaminant issues at the refuge. } \\
\text { Example: Ground water models discussed at meeting } \\
\text { indicate that carbon tetrachloride sources at site are not } \\
\text { hydrologically connected to aquifers proximal to refuge. }\end{array}$ & Character limit: 2,000 \\
\hline
\end{tabular}


Section 2 - Backpround Information - Meethas

Thinh NWR
Men Meso P

Section Meou fry

Help

TularTepte of the Meethor

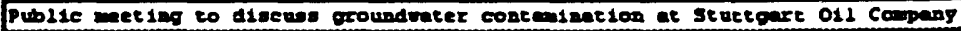

Mesthe Date: Lpr 11 12, 1997

Marthe Orgatber(s):

Dr. Geome T. Alion

1): +1, tluthind

Stow Knowles

Lery Moil

John Miesner

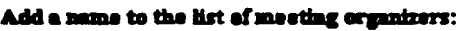

Prst wan Dr. Tr18z

Laxt ane Roppt

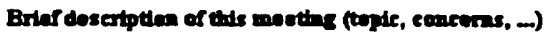

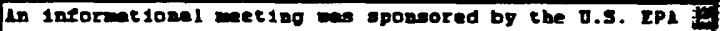

to update locel thateholders on the status of efrotts

to clean up carbon tetrachloride found in domeet ic

vel10 anar the Stuttgart Oll Compang. Groundreter

podels rere discumed.

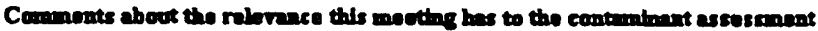

Groundrecer wodels drecussed at wet18g lodscate that

certong tetracbloride sources at alte are not

cydrologlce $11 \mathrm{y}$ connected to aquifers proximl to refugetio

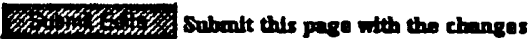

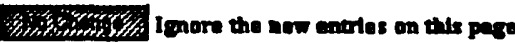

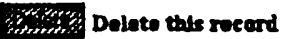

Figure 2-3. Data entry screen: Background Information - Meetings. 


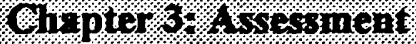
Contidertinon:

\section{Section 1. Overview}

Section 3 of the data management system is used to document the geophysical context, wildlife resources, management activities, and strategies of the refuge. Information documented in this section will provide a better understanding of the biological receptors that may be sensitive to contaminants. In addition, it will give the Primary Investigator insight into land use activities on and off the refuge that may influence contaminant transport and effects. The information collected in this step will support a broader understanding of the relationships that exist between the wildlife resources, habitats, and management actions of the refuge.

There are four information subsections in this section of the data management system. A finite number of records are available for each subsection [General Information (7); Plant and Animal Species (23); Land Cover/Land Use (26); and Management Activity (10)]. The data management system automatically queries and retums available information from RMIS for each record within the subsection. The RMIS information is read-only and cannot be edited by CAP users. Vegetation types were derived from the National Vegetation Classification System.

Initially, the topics for the General Information subsection are listed under the heading "Topics Not Addressed." As information is entered for the topics, they are moved and listed under "Topics Addressed." Similarly, topics for the Species Assessment, Land Cover/Land Use, and Management Activity subsections are listed under the heading "Not Applicable." As information is entered for topics for these subsections, they are moved to the heading "[topic] Addressed." If no information is entered into records within the subsection, the database will default to "Not Applicable." Information entered into these four subsections is not automatically linked to other sections. 
Section 3. Guidance for

Data Entry and Analysis: General Information
The General Information subsection involves entering information for a finite number of topics that apply to the refuge. Given the generic nature of the information required in this subsection, the user should be able to enter comments for all the topics. Guidance for entering information for the "Comments on [topic]" and "Relevance to the Contaminant Assessment" fields are provided below. Because all of the data entry screens for this subsection are identical in format, only one example is provided.

Biodiversity: Comments: Describe particular efforts underway at the refuge to enhance or protect the diversity of life across a spectrum of organizational levels, including genetic, population, community, ecosystem, and landscape. Specific efforts may give an indication of species or habitats that are of special concern to refuge management.

Relevance: Describe how contaminants may influence the refuge's ability to achieve management objectives related to biodiversity.

Description: Comments: Provide details about the refuge including its location, size, climate, dominant physical and biological features that may influence this assessment.

Relevance: Describe how the geophysical characteristics or administrative considerations (i.e., water rights or conservation easements) of the refuge might influence the degree to which contaminants reach the unit or whether they might tend to influence their impacts.

Documented Contaminant Concerns: Comments: List any contaminant concerns that have been documented at the refuge. Concerns that could be considered "documented" include those which have been evaluated through field observations or the application of biological or chemical analysis techniques. Relevance: Describe how the documented contaminant concerns might impact FWS-managed habitats or species.

Geographic Location of Area: Comments: Describe the geographic location of the refuge. Note any unusual circumstances regarding its location relative to administrative (state, county boundaries), legislative, (congressional district) or hydrological boundaries. Describe its proximity to urban centers, agricultural operations, and its orientation within the watershed. Describe any internal divisions of the refuge.

Relevance: Describe how the geophysical characteristics of the refuge might influence the degree to which contaminants reach the unit or whether they might tend to maximize their impacts.

Refuge Purpose and Goals: Comments: Summarize the "legal purposes" for which the refuge was established and any internally-approved conservation or recreation goals. If no information is returned from RMIS, check with staff for citations listing the refuge purpose(s) and goals.

Relevance: Note how contaminants might impact any conservation recovery or protection goals set by the refuge.

Other/Suspected Contaminant Concerns: Comments: List any potential contaminant concerns at the refuge that, while suspected, have not been documented through field observations or analytical methods.

Relevance: Describe how any suspected contaminant concerns might impact FWS-managed habitats or species.

Threatened/Endangered Species: Comments: List the names of threatened and endangered species that reside or use refuge habitat. Describe any management objectives for these species.

Relevance: Describe how potential contaminant issues on the unit might affect or influence the success of restoration or recovery efforts underway. 
Table 3-1. Field descriptions and examples: Assessment Considerations - General Information.

\begin{tabular}{l|l|l}
\hline Field Name & \multicolumn{1}{|c|}{ Content Guidance/Example } & \multicolumn{1}{|c}{ Data Entry Tips } \\
\hline $\begin{array}{l}\text { Data from } \\
\text { RMIS/ } \\
\text { CIMAS }\end{array}$ & $\begin{array}{l}\text { The system returns information from either RMIS or CIMAS } \\
\text { for all fields in this section except biodiversity and refuge } \\
\text { purpose and goals. }\end{array}$ & $\begin{array}{l}\text { Read only. } \\
\text { Information derived } \\
\text { from database queries. }\end{array}$ \\
\hline $\begin{array}{l}\text { Comments on } \\
\text { \{topic\} }\end{array}$ & $\begin{array}{l}\text { Review the guidance contained in Section } 3 \text { of this Chapter and } \\
\text { enter relevant information in the field. }\end{array}$ & Character limit: 2,000 \\
\hline $\begin{array}{l}\text { Relevance to } \\
\text { assessment }\end{array}$ & $\begin{array}{l}\text { Review the guidance contained in Section } 3 \text { of this Chapter and } \\
\text { enter relevant information in the field. }\end{array}$ & Character limit: 2,000 \\
\hline
\end{tabular}


Secton 3 - General Information

Kinth NWR - Blodtverdty
Man Mem [T]

Section Menu

Help

Dem trem RMIS:

No infermonion avilatie.

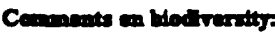

The refuoc provides ming types of bableat to support if

alverse populations or enimale. Due to che retuoe's

location neer exe veographical center of ceh

contineatal valted states, It talle vichlo the extrene Th

ranges of blxd apeciea Ixo all areet of che country.

To cate, 200 apecies or birda bove been 1deatiz1ed on if

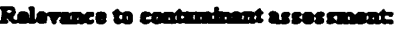

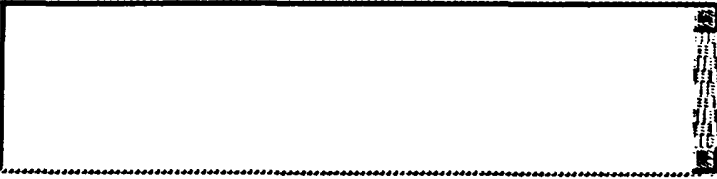

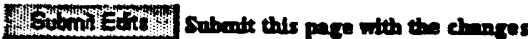

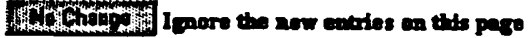

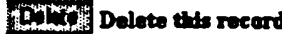

Figure 3-1. Data entry screen: General Information - Biodiversity. 
Section 4. Guidance for Data Entry and Analysis: Species Assessment
This Section is used to document characteristics about species present at the refuge that may influence their exposure or susceptibility to environmental contaminants. The purpose of this section is NOT to document the presence of every species present at the refuge. Rather, the purpose is to ensure that the Primary Investigator reviews the categories of animals in order to make plausible links between species and potential contaminant threats. Considerations that should be documented include factors that may increase the likelihood that species are exposed to environmental contaminants. These include behavioral, temporal, or spatial considerations that may result in a species co-occurring with contaminants. Information about known species sensitivities to contaminants or life-stages sensitivities should be documented. Population declines that might be related to contaminant effects should also be noted. Where appropriate, document situations where species have been monitored in an area or used in studies or considered indicators for contaminant exposure or effects. Resident freshwater fish species and resident marine fish species should be entered under the "Other aquatic species" category.
- Amphibians

- Exotic/pest species

- Manumals - terrestrial

- Other freshwater species

- Other species

- Raptors

- Shorebirds

- Waterfowl
- Anadromous fishes

- Macroinvertebrates

- Non-mammal marine organisms

- Other migratory birds

- Plants - aquatic

- Reptiles

- State listed/candidate

- Wildlife, other resident species
- Catadromous fishes/invertebrates

- Mammals - marine

- Other aquatic birds

- Other resident birds

- Plants - terrestrial

- Seabirds

- Federal T\&E/candidate species 
Table 3-2. Field descriptions and examples: Assessment Considerations - Species Assessment.

\begin{tabular}{l|l|l}
\hline Field Name & \multicolumn{1}{|c}{ Content Guidance/Erample } & Data Entry Tips \\
\hline $\begin{array}{l}\text { Data from } \\
\text { RMIS }\end{array}$ & $\begin{array}{l}\text { The RMIS system currently does not contain specific } \\
\text { information that can be used in this form. This link is primarily } \\
\text { a placeholder in the event that this information becomes } \\
\text { available in the future. }\end{array}$ & $\begin{array}{l}\text { Read only. } \\
\text { Information derived } \\
\text { from database queries. }\end{array}$ \\
\hline $\begin{array}{l}\text { Comments on } \\
\text { \{topic\} }\end{array}$ & $\begin{array}{l}\text { Review the guidance contained in the Section 3, page 3-2 of } \\
\text { this Chapter and enter relevant information in the field. }\end{array}$ & Character limit: 2,000 \\
\hline $\begin{array}{l}\text { Relevance to } \\
\text { assessment }\end{array}$ & $\begin{array}{l}\text { Review the guidance contained in Section 3, page 3-2 of this } \\
\text { Chapter and enter relevant information in the field. }\end{array}$ & Character limit: 2,000 \\
\hline
\end{tabular}


Section 3 - Assesment Considerutions - Spedes

Man Mems in

Arsessment

Section Menu

Krntu NWR - Amphibians

Hetp

Deta fren RMIs:

No information avilable.

Counents en spedies thes:

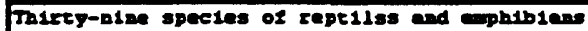

potentially oceur 10 Phildpe County. Ho

pederally-11sted ebrsacened or endangered rept1lea or

ophiblans oceur on the resure. The presence or two

stere 'species in peed os conservation', ine eastern

and vesters boo-bose snabs, bas been conf1rwed.

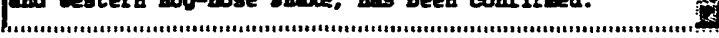

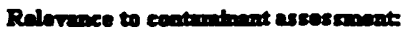

Pestlezdes on ebe resuge could pose a serious problem

ror repelile and ophibian apecies.

\section{is

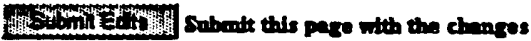

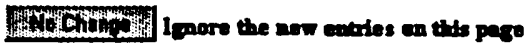

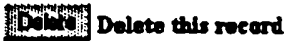

Figure 3-2. Data entry screen: Assessment Considerations - Species Assessment. 
Section 5. Guidance for Data Entry and Analysis: Land Cover/Land Use
The Land Cover/Land Use subsection is used to document landscape characteristics and vegetation patterns on and near the refuge that may influence the presence, transport, or fate of environmental contaminants. Shifts in historic land use patterns, descriptions of dominant plant communities, exotic species, and impacts from human activities (urbanization, silviculure, agriculture) on the landscape and distribution of vegetation are some factors that should be documented. Entries for the appropriate categories should provide the location and extent of the vegetation type. Note in particular any overlap between potentially contaminated landscape features which may be preferred habitat for certain species, which increase their exposure risk. Information sources include National Wetland Inventory maps, GAP analyses products, refuge-specific maps, and Natural Heritage Maps.
- Agricultural lands

- Deciduous shrubland

- Evergreen dwarf shrubland

- Evergreen woodland

- Forb-dominated vegetation

- Managed wetlands

- Other habitat

- Saltflats/mudflats

- Tall grassland
- Deciduous dwarf shrubland

- Deciduous woodland

- Evergreen forest

- Ext. xeromorphic dwarf shrubland

- Hydromorphic freshwater vegetation

- Marine

- Other wetlands

- Short grassland

- Tundra
- Deciduous forest

- Estuarine

- Evergreen shrubland

- Ext. xeromorphic shrubland

- Lake/pond/impoundment

- Medium-tall grassland

- Riverine

- Strandland (beach) 
Table 3-3. Field description and examples: Assessment Considerations - Land Cover/Land Use.

\begin{tabular}{l|l|l}
\hline Field Name & \multicolumn{1}{|c|}{ Content Guidance/Example } & Data Entry Tips \\
\hline $\begin{array}{l}\text { Data from } \\
\text { RMIS }\end{array}$ & $\begin{array}{l}\text { The RMIS system currently does not contain specific } \\
\text { information that can be used in this form. This link is primarily } \\
\text { a placeholder in the event that this information becomes } \\
\text { available in the future. }\end{array}$ & $\begin{array}{l}\text { Read only. } \\
\text { Information derived } \\
\text { from database queries. }\end{array}$ \\
\hline $\begin{array}{l}\text { Comments on } \\
\text { \{topic\} }\end{array}$ & $\begin{array}{l}\text { Review the guidance contained in Section 3, page 3-2 of this } \\
\text { Chapter and enter relevant information in the field. }\end{array}$ & Character limit: 2,000 \\
\hline $\begin{array}{l}\text { Relevance to } \\
\text { assessment }\end{array}$ & $\begin{array}{l}\text { Review the guidance contained in Section 3, page 3-2 of this } \\
\text { Chapter and enter relevant information in the field. }\end{array}$ & Character limit: 2,000 \\
\hline
\end{tabular}


Section 3 - Asseasment Considerutions - Ind Coverhand Use

Denten RMIs:

No information avilable.

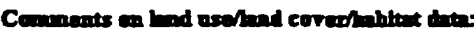

Approximete15 95t of all Defupe uplande cere tarned

pe $10 \mathrm{r}$ to Gover:me equlestion. Following

ecquialicion, areen ldeatified a not being sultable for

tarming vere reven out or production wich the better

areas being retalned lor vildilfe lood production. The so

resuce current 19 has approximete 19 1,600 acres or

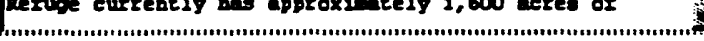

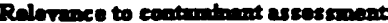

Old converted cropland and currene cropland should be

eveluaced tor the presence or lingering africulturel

cherleals such w arsenic, DDT, organochlorines, ete.

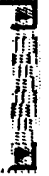

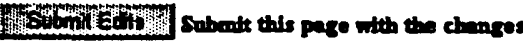

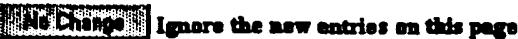

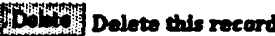

Figure 3-3. Data entry screen: Assessment Considerations Land Cover/Land Use. 
Section 6. Guidance for Data Entry and Analysis: Management Activity
The Management Activity subsection is used to document ongoing or historic resource management actions taken at the refuge. Considerations that should be documented include land uses associated with extracting natural resources, public and military use, and agriculture. Note habitat effects (i.e., erosion, leaching, and acid drainage) which may be associated with extractive, recreation, and military land uses. Ongoing and historic research efforts and water management operations should be noted. Describe oil/gas operations, pipelines, farming, and subsistence fishing/hunting under the category "Other."

Information entered in the Comments field should focus on describing the location, scale, intensity, and duration of the activities. Information entered in the Relevance field should focus on interpreting how these activities might influence the presence, movement, or fate or effects of environmental contaminants on the unit.
- Grazing

- Mining

- Previous baseline or reference

- Wilderness
- Logging

- On-site pest management activities

- Recreational activities
- Military

- Other use

- Research for species not T\&E monitoring 
Table 3-4. Field descriptions and examples: Assessment Considerations - Management Activity.

\begin{tabular}{l|l|l}
\hline Field Name & \multicolumn{1}{|c|}{ Content Guidance/Example } & \multicolumn{1}{|c}{ Data Entry Tips } \\
\hline $\begin{array}{l}\text { Data from } \\
\text { RMIS }\end{array}$ & $\begin{array}{l}\text { The RMIS system currently does not contain specific } \\
\text { information that can be used in this form. This link is primarily } \\
\text { a placeholder in the event that this information becomes } \\
\text { available in the future. }\end{array}$ & $\begin{array}{l}\text { Read only. } \\
\text { Information derived } \\
\text { from database queries. }\end{array}$ \\
\hline $\begin{array}{l}\text { Comments on } \\
\text { \{topic\} }\end{array}$ & $\begin{array}{l}\text { Review the guidance contained in Section 3 of this Chapter and } \\
\text { enter relevant information in the field. }\end{array}$ & Character limit: 2,000 \\
\hline $\begin{array}{l}\text { Relevance to } \\
\text { assessment }\end{array}$ & $\begin{array}{l}\text { Review the guidance contained in Section } 3 \text { of this Chapter and } \\
\text { enter relevant information in the field. }\end{array}$ & Character limit: 2,000 \\
\hline
\end{tabular}


Section 3 - Assessment Considerations - Manngement Activity Assessment

Konth NWR - Grating

Dene trom RMIs:

No information areilable.

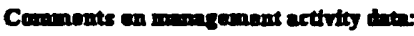

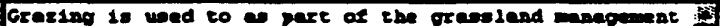

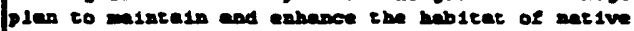

ppecies of tlore and fause. Cown are used to simulace che orazing once pezormed by biand and obeer fildilfe.

Gresing is used to accrease undesirable species and

increase desirable opecies. Then properly used.

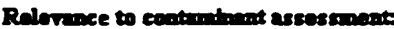

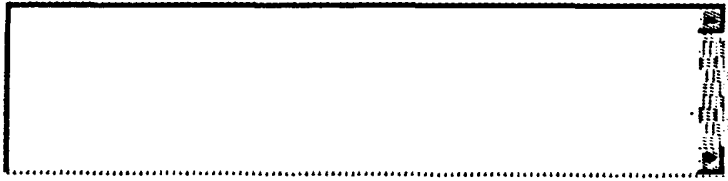

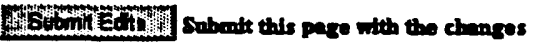

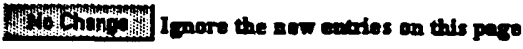

Don Delete this rocerd

Figure 3-4. Data entry screen: Assessment Considerations Management Activity. 
\%18pter. $\% .0001811$ Tinterior. 1.70 .

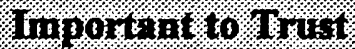

10-0110-0.110] intersinent

\section{Section 1. Overview}

Section 4 of the data management system is used to identify local areas surrounding the refuge where trust species might be exposed to contaminants. Because the movement of trust species is rarely confined to FWS-managed lands, a comprehensive assessment must include an evaluation of areas beyond FWS-management boundaries that may pose direct or indirect contaminant exposure risks. Trust species may be exposed to contaminants on local areas outside the boundary of the refuge that provide feeding, rearing, or nesting habitats. In some cases, these areas may be outside the identified AOIs for the various transport pathways. This part of the assessment can provide important clues in situations where trust species have experienced die-offs or declines in the absence of contaminated refuge habitats.

Once the areas are identified, the Primary Investigator should evaluate the likelihood that biological resources might be exposed to ecologically significant amounts of environmental contaminants. To document threats posed to biological resources using these sites, these areas are categorized according to the level of known or suspected level of contamination. The level of contamination at each site should be assigned according to the guidelines provided in this section. Information provided by refuge biologists, local experts, or other sources identified in Section 2 - Background Information of the data management system should be reviewed as the basis for assigning the level of contamination at the areas. In some cases, field reconnaissance visits may be necessary to document the potential level of contamination at the identified areas.

The primary purpose of this step in the CAP is to characterize the intrinsic level of contamination at the site that may result in exposure of biological resources. Occasionally, activities at the identified areas will result in the release of contaminants from point or nonpoint sources that may reach the refuge. In these cases, point and nonpoint sources located at the site should be documented in Section 6 Contaminant Source Information.

Known contaminant sources and documented contamination problems and/or habitat degradation.

- Contaminant presence and effects have been identified and documented at this location.

- Contaminant is present and is a threat to the system and/or humans. 
Contamination Level 2

Contamination Level 3

Contamination Level 4
- Significant effects to the system have been observed (die-offs, morphological/physiological/behavioral effects, habitat degradation, etc.). However, the specific cause(s) might not be known.

- Regulatory levels have been reached for a contaminant or a contamination event has occurred to initiate mitigative/ remedial actions or additional studies.

- A contaminant problem has been identified at this location and mitigative or remediation measures have been implemented to resolve the problem. However, the situation still requires special studies or long-term monitoring to verify that the mitigation/remediation activities are effective.

Known contaminant sources and contaminant presence, no documented contaminant problems or habitat degradation.

- Contaminants very likely (or known) to exist or to be moving to this location, but a specific problem has not been identified.

- Contaminant sources exist upstream (upgradient, upwind) within close proximity to or on the refuge.

- Regulatory requirements relevant to monitoring are not being adequately addressed at this location.

Known contaminant sources, suspected contaminant presence, no documented contaminant problems or habitat degradation.

- Potential contaminant sources exist.

- Suspected sources exist on or off the refuge and transport pathways have been identified to this location. However, contaminants have a low probability of reaching this site and affecting the system.

No known contaminant sources other than global atmospheric input and no known habitat degradation.

- Relatively uncontaminated location intersected by a transportation route.

- No known or suspected contaminant sources (other than those associated with the transportation route). 
- Transportation route (railway, highway, navigation channel) is upstream, upwind, or upgradient and is known as a route for carriers of various hazardous substances.

- No known degradation of the resource. However, future spills at the site are a credible concern.

Section 2. Data

Management System Operation
The information required for this section is recorded on as many records as necessary. Names of contacts listed in this section of the data management system are derived from those entered in Section 2 Background Information: Contacts. Names of contacts added in this section are also automatically appended to the picklist of individuals recorded in Section 2 - Background Information: Contacts. 


\section{Section 3. Guidance for Data Entry and Analysis: Local Off-Interior Lands Important to} Trust Resources

Table 4-1. Field descriptions and examples: Local Off-Interior Lands Important to Trust Resources.

\begin{tabular}{l|l|l}
\hline \multicolumn{1}{|c|}{ Field Name } & \multicolumn{1}{|c}{ Content Guidance/Erample } & Data Entry Tips \\
\hline $\begin{array}{l}\text { Name of the } \\
\text { area }\end{array}$ & $\begin{array}{l}\text { Enter the name of the area used by trust resources or give it an } \\
\text { identification number. Example: Adjacent Agricultural Lands. }\end{array}$ & Character limit: 80 \\
\hline $\begin{array}{l}\text { Location/ } \\
\text { Address }\end{array}$ & $\begin{array}{l}\text { Enter a description of the area and/or a street address to assist in } \\
\text { locating the area. Erample: The adjacent agricultural lands } \\
\text { include lands upstream (south) from the refuge as well as two } \\
\text { parcels which are within refuge boundaries but that are } \\
\text { farmed by a private landowner. The two parcels are located } \\
\text { outside the dike on the east side of the refuge. Although the } \\
\text { Nisqually Indian Tribe officially manages these areas, the past } \\
\text { owner has life use of the property and continues to hay the } \\
\text { area. Primarily to the south of the refuge agricultural, dairy, } \\
\text { and livestock operations exist. These farmlands are in the same } \\
\text { watershed as the refuge; therefore, land practices such as } \\
\text { burming, plowing, fertilizer use and pesticide use could } \\
\text { potentially influence refuge water and air quality.. }\end{array}$ & Character limit: \\
\hline
\end{tabular}

UTM Coordinates. Enter either Universal Transverse Mercator (UTM) or latitude and longitude coordinates) that correspond to the approximate center of the identified area.

\begin{tabular}{l|l|l}
\hline $\begin{array}{l}\text { UTM “X” } \\
\text { (easting) }\end{array}$ & $\begin{array}{l}\text { Enter the 6-digit "X" UTM coordinate for the area. } \\
\text { Example: None given. }\end{array}$ & $\begin{array}{l}\text { Character limit: } 6 \\
\text { ", not allowed. }\end{array}$ \\
\hline $\begin{array}{l}\text { UTM “Y” } \\
\text { (northing) }\end{array}$ & $\begin{array}{l}\text { Enter the 7-digit "Y" UTM coordinate for the area. } \\
\text { Example: None given. }\end{array}$ & $\begin{array}{l}\text { Character limit: } 7 \\
\text { ", not allowed. }\end{array}$ \\
\hline UTM zone & $\begin{array}{l}\text { Enter the 2-digit UTM zone identifier in which the coordinates are } \\
\text { located. Example: None given. }\end{array}$ & $\begin{array}{l}\text { Character limit: } 2 \\
\text { "," not allowed. }\end{array}$ \\
\hline Degrees & $\begin{array}{l}\text { Enter the degrees of latitude for the identified area. Example: } \\
\text { None given. }\end{array}$ & Character limit: 2 \\
\hline Minutes & $\begin{array}{l}\text { Enter the minutes of latitude for the identified area. Example: } \\
\text { None given. }\end{array}$ & Character limit: 2 \\
\hline Seconds & $\begin{array}{l}\text { Enter the seconds of latitude for the identified area. Erample: } \\
\text { None given. }\end{array}$ & Character limit: 2 \\
\hline
\end{tabular}


Section 4 - Local Off-Interior Areas Important to

Trast Resources

Nisqually NWR

Name of the area

Idjecent Lgricultural Lands

Please enter at least one of the following: location of the area, UTM Coordinates $\alpha$ and $Y$ ), or Latitude and Lonpitude

Location/Address

The adjacent arricultural lands include lands upstream (souch) Irow the refuge as well as two parcels obleh

are fithln refuge boundaries but chat are larmed by a

private lendowner. The two parcels are locaced outside

the dilce on the ease side of the refuge. Llthough the

Nisqual1g Indian Tribe offlctelly manages these areas,

UTM Coordmates

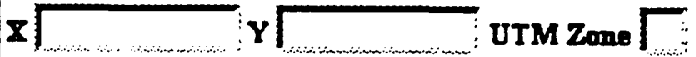

Latitude

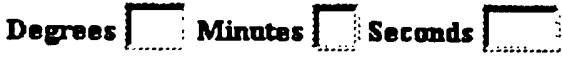

Figure 4.1 Data entry screen: Local Off-Interior Lands Important to Trust Resources. 
Table 4-1. Continued.

\begin{tabular}{|c|c|c|}
\hline Field Name & Content Guidance/Erample & Data Entry Tips \\
\hline \multicolumn{3}{|c|}{ Longitude } \\
\hline Degrees & $\begin{array}{l}\text { Enter the degrees of longitude (up to } 3 \text { digits) for the identified } \\
\text { area. Example: None given. }\end{array}$ & $\begin{array}{l}\text { Character limit: } 4 \\
\text { ("-" in N. America) }\end{array}$ \\
\hline Minutes & $\begin{array}{l}\text { Enter the minutes of longitude for the identified area. Example: } \\
\text { None given. }\end{array}$ & Character limit: 2 \\
\hline Seconds & $\begin{array}{l}\text { Enter the seconds of longitude for the identified area. Example: } \\
\text { None given. }\end{array}$ & Character limit: 2 \\
\hline \multicolumn{3}{|c|}{ Level of Contamination } \\
\hline $\begin{array}{l}\text { Select the level } \\
\text { of contamination } \\
\text { that applies to } \\
\text { this area }\end{array}$ & $\begin{array}{l}\text { Based on the guidance in this chapter, select one of the four } \\
\text { contamination levels displayed on the data entry screen that best } \\
\text { describes the area. Example: Level } 1 \text { - Known contaminant } \\
\text { sources and documented contamination problems and/or } \\
\text { habitat degradation. }\end{array}$ & $\begin{array}{l}\text { Radio button. Single } \\
\text { selection allowed. }\end{array}$ \\
\hline $\begin{array}{l}\text { Description of } \\
\text { areas' } \\
\text { importance to } \\
\text { study }\end{array}$ & $\begin{array}{l}\text { Describe the extent and geo-physical characteristics of the area. } \\
\text { Describe value of area to trust resources (feeding, nesting, } \\
\text { rearing). Identify times of year that the area is used by trust } \\
\text { resources. Provide supporting information concerning known or } \\
\text { suspected contaminants present in the area if it is assigned a } \\
\text { contamination level of 1-3. Note if any contaminant monitoring or } \\
\text { investigations have taken place in the area. Where appropriate, } \\
\text { identify potential for trust species to bioaccumulate and transport } \\
\text { contaminants to the refuge. Example: Although contaminants } \\
\text { associated with the haying practice within refuge boundaries } \\
\text { have not been documented, they are suspected. These and } \\
\text { other adjacent farmlands are used to grow crops and are } \\
\text { subject to a wide range of pesticide treatments, including some } \\
\text { pesticides, such as aldicarb and parathion not currently } \\
\text { allowed on refuge lands. Aerial drift of pesticides from these } \\
\text { lands or leaching to irrigation waters on refuge lands may } \\
\text { occur. Finally, fecal coliform from upstream agricultural } \\
\text { practices have been documented and the habitat, namely } \\
\text { shellfish habitat, has been adversely effected especially } \\
\text { following storm events by the conditional closure of shellirish } \\
\text { barvest. }\end{array}$ & Character limit: 2,000 \\
\hline
\end{tabular}




\section{Longttude \\ Degrees \\ Mtmutes Seconds}

Seleet the level of combentention that applies to this area

C. Level 1 - Known contaminant sources and documented contamination problems and/or babitat degradation

6. Level 2 - Known contaminant sources and contaminant presence, no documented contaminant problems or habitat degradation

C. Level 3 - Known contaminant sources, suspected contaminant presence, no documented contaminant problems or habitat degradation

C Level 4 - No bnown contaminant sources other than global atmospheric input and no known habitat degradation

Descrtption of area and inportance to study: (If Levels 1-3 were chosen enter rationale of why this is a known contaminant source).

Although conteminants associated vith the haging pracelce otehin refuge boundarles heve not been docwented, they are suspected. These and other adjacent farmlands are used to grov crops and are subject to a vide range or pesticlde rreatments, lncluding some peseleldes, sucb as aldicarb and paratbion not current $1 \mathrm{y}$ alloved on retuge lands. lerlal drite of pesticldes $150 \mathrm{~m}$ these lands or leachlog to 1rrigation maters on refuge lands way occur. Finallg. Iecal col1form from upseream agriculcural

Figure 4-1. Continued. 
Table 4-1. Concluded.

\begin{tabular}{l|l|l}
\hline \multicolumn{1}{c|}{ Field Name } & \multicolumn{1}{c}{ Content Guidance/Example } & \multicolumn{1}{c}{ Data Entry Tips } \\
\hline $\begin{array}{l}\text { Contacts } \\
\text { linked to this } \\
\text { area }\end{array}$ & $\begin{array}{l}\text { Select name of contact with information about area from } \\
\text { picklist. If the contact's name is not displayed in the picklist, } \\
\text { enter the new name in the fields provided. Add a name to the } \\
\text { contacts list. Existing names can be selected or the name of a } \\
\text { new contact entered in the section titled “Add a new name to } \\
\text { contact list". Erample: Bill Cleland, Bob Wollrich. }\end{array}$ & $\begin{array}{l}\text { Picklist: Multiple } \\
\text { selections allowed. } \\
\text { Defaults to “None". } \\
\text { Click on one or more } \\
\text { names in picklist. }\end{array}$ \\
\hline \multicolumn{3}{|c}{ Add a New Name to the Contacts List } \\
\hline First name & $\begin{array}{l}\text { Enter the first name of the contact that has information } \\
\text { regarding the identified area. Example: Mr. Brian R. }\end{array}$ & Character limit: 40 \\
\hline Last name & $\begin{array}{l}\text { Enter the last name of the contact that has information } \\
\text { regarding the identified area. Example: Smith. }\end{array}$ & Character limit: 40 \\
\hline
\end{tabular}


Contacts Ifnked to this area:

Bill Cleland

Bob Woolich

Jay Davis

Willard Bill' Hesselbar

Brendan McFarland : is

Add a new name to the contacts list

Fist name

PobmitEdf

WOChanger Ienore the now entries on this page

Dolete: Delete this record

Figure 4-1. Concluded. 


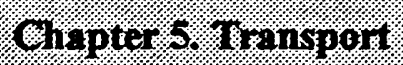

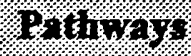

\section{Section 1. Overview}

\author{
Section 2. Data \\ Management System \\ Operation
}

Section 5 of the data management system is used to identify and describe the physical characteristics and relative importance of the contaminant transport pathways for each contaminant transport mechanism. As explained in Part 1 - Chapter 2, contaminant transport pathways are identifiable avenues within a transport mechanism through which the bulk of transported contaminants move.

Contaminant transport mechanisms refers to the media that carries contaminants from their sources through the environment to receptors (organisms or habitats). Four transport mechanisms are considered in this assessment: surface water, ground water, air, and biota.

Delineating the AOI and identifying the pathways for each mechanism focuses the analyses of contaminant sources to areas where released chemicals are likely to reach the refuge.

Do not use this section to enumerate contaminant source information. Document individual source information in Section 6: Contaminant Source Information.

There are four subsections of information required in this section:

$\begin{array}{ll}\text { - surface water } & \text { - ground water } \\ \text { - air } & \text { - biota }\end{array}$

An unlimited number of records can be entered for surface water, ground water, and biota. Eight records (one for each cardinal direction) are available for the air transport subsection. The names of pathways in this section are displayed in a picklist for each record in Section 6: Contaminant Source Information. Maps displaying the extent of the AOIs (8-digit HUC and the $150 \mathrm{~km}$ buffer) are available by selecting the "View Maps" option on the Main Menu. 
Section 3. Guidance for Data Entry and Analysis: Surface Water
Describe the location, drainage, and general characteristics of rivers, streams, lakes, ponds, and canals within the AOI (i.e., the 8digit HUC) that could directly or indirectly convey contaminants from their sources to the refuge. This information provides the user with a broader understanding of the hydrological characteristics in the watershed that could transport contaminants to the refuge. This section should not be used to describe individual contaminant sources which may discharge into the pathway. Source identification is performed in Section 6: Contaminant Source Information.

Currently, the data management system provides a small scale (coarse) map depicting the extent of the 8-digit HUC. This map does not provide sufficient detail to allow the identification of individual surface waterbodies. It is recommended that users identify surface water features within the HUC by using appropriately scaled digital or hardcopy USGS topographic or National Wetland Inventory maps. 
CAP USER'S GUIDE 
Table 5-1. Field descriptions and examples: Transport Pathways - Surface Water.

\begin{tabular}{|c|c|c|}
\hline Field Name & Content Guidance/Erample & Data Entry Tips \\
\hline $\begin{array}{l}\text { Name of the } \\
\text { watercourse }\end{array}$ & $\begin{array}{l}\text { Identify lakes, ponds, streams, rivers, canals, estuaries, and tidal } \\
\text { influences which may convey contaminants from their sources to the } \\
\text { refuge. Example: Bow Creek. }\end{array}$ & Character limit: 80 \\
\hline $\begin{array}{l}\text { Describe the } \\
\text { location of the } \\
\text { item in relation } \\
\text { to the Interior } \\
\text { land }\end{array}$ & $\begin{array}{l}\text { Document the location of standing waterbodies and the course of } \\
\text { flowing waterbodies relative to the refuge boundaries. Describe on- } \\
\text { and off-refuge habitats associated with the waterbodies. Describe the } \\
\text { strength and precocity of tidal influences. Example: Flows into the } \\
\text { south end of the reservoir/refuge. }\end{array}$ & Character limit: 2,000 \\
\hline $\begin{array}{l}\text { Description } \\
\text { and/or comments } \\
\text { about the surface } \\
\text { item and its } \\
\text { importance to } \\
\text { the study }\end{array}$ & $\begin{array}{l}\text { Describe dominant land uses in the drainage of the surface } \\
\text { waterbody. Document gradient and flow for streams and rivers } \\
\text { (average discharge, seasonal fluctuations). Identify any ratings } \\
\text { assigned by state or federal regulatory authorities to the waterbody. } \\
\text { Describe any documented water quality issues affecting the } \\
\text { waterbody (turbidity, increased temperature, high alkalinity). Do not } \\
\text { use this field to document contaminant point sources. Example: } \\
\text { Bow Creek contributes a significant portion of water to the } \\
\text { Reservoir/Refuge. The combined drainage area of the North } \\
\text { Fork and Bow Creek is } 1,373 \text { acres. Like the North Fork, } \\
\text { agriculture (farming and ranching) is the major economic use. It } \\
\text { is likely that Bow Creek has erperienced similar problems as } \\
\text { the North Fork, including fish and wildlife problems, reduced } \\
\text { stream flows, depletion of groundwater reserves, loss of } \\
\text { riparian, stream and upland habitat, deteriorated water quality } \\
\text { and poor land use practices. Investigations indicate that } \\
\text { agricultural activities (farming and ranching) can be major } \\
\text { factors in these problems. Irrigation typically increases soil } \\
\text { erosion and water runoff and may be the greatest single factor } \\
\text { in the reduction of groundwater and stream flow. Receiving } \\
\text { streams have been degraded due to loss of flow and the influx of } \\
\text { salts, pesticides, and nutrients carried in field runoff. Much of } \\
\text { the bottomland is farmed or over-grazed to the banks of the } \\
\text { creek and tributaries, often resulting in ertensive clearing of } \\
\text { native riparian vegetation, increased erosion, and nutrient } \\
\text { loading. }\end{array}$ & Character limit: 2,000 \\
\hline
\end{tabular}


Section S - Surfece Water Trangport Pathums

Krinin NWR
Men Mems

Section Meou

Help

Nowe of the wetereourse:

Pou Creex

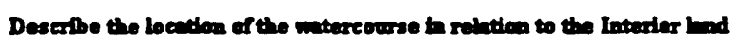

Flow 1nco the wouth and of the Regervole/Refuge.

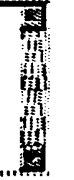

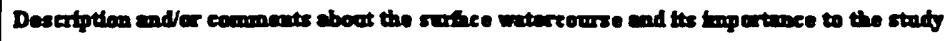

Bov Creex concribuces a siomificant port10n of water to $\$$

the Reservoli/Retuge. The comblaed dralange area of

the Noreb Jork and Bor Creek 10 1,373 ceres. Iibe the th

North Fork orrioulture (leaming and zenching) is the

wajor eoonowie ue. It 18 libely that Bou Creek beo

experienoed almilar problew at the North Tork

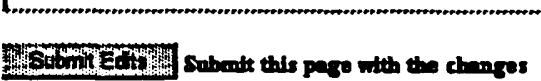

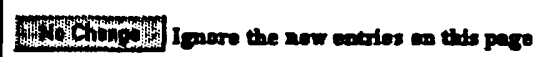

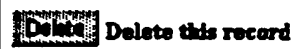

Figure 5-1. Data entry screen: Transport Pathways - Surface Water. 
Section 4. Guidance for Data Entry and Analysis: Ground Water
Describe the aquifer characteristics that could directly or indirectly convey contaminants from their sources to the refuge. This information, in addition to the surface water subsection, provides the user with a broader understanding of the hydrological characteristics in the watershed that could transport contaminants to the refuge. Do not use this section to describe individual contaminant sources which may discharge into the pathway. Source identification is performed in Section 6: Contaminant Source Information.

Currently, the data management system provides a small scale (coarse) map depicting the extent of the 8-digit HUC. This map does not provide information on ground water resources. It is recommended that users identify aquifers by acquiring information from state or federal hydrology sources. 
Table 5-2. Field descriptions and examples: Transport Pathways - Ground Water.

\begin{tabular}{|c|c|c|}
\hline Field Name & Content Guidance/Example & Data Entry Tips \\
\hline $\begin{array}{l}\text { Name of the } \\
\text { ground water } \\
\text { pathway }\end{array}$ & $\begin{array}{l}\text { Identify aquifers which may convey contaminants from their sources } \\
\text { to the refuge. Example: Dakota Aquifer. }\end{array}$ & Character limit: 80 \\
\hline $\begin{array}{l}\text { Describe the } \\
\text { location of the } \\
\text { item in relation } \\
\text { to the Interior } \\
\text { land }\end{array}$ & $\begin{array}{l}\text { Document the location of the aquifers relative to the refuge } \\
\text { boundaries. Note in particular the locations of springs, seeps, wells, } \\
\text { or pumps on or near the refuge. Document routine use of ground } \\
\text { water for irrigation or other purposes on the refuge which may } \\
\text { constitute a route of exposure for wildlife. Erample: The Dakota } \\
\text { Aquifer underlies most of the western two-thirds of Kansas, } \\
\text { including Phillips County and the reservoir/refuge. Phillips } \\
\text { County and the reservoir/refuge lie in the confined region of the } \\
\text { aquifer's range which is overlain by the Upper Cretaceous } \\
\text { aquitard. }\end{array}$ & Character limit: 2,000 \\
\hline $\begin{array}{l}\text { Description } \\
\text { and/or comments } \\
\text { about the surface } \\
\text { item and its } \\
\text { importance to } \\
\text { the study }\end{array}$ & $\begin{array}{l}\text { Describe dominant land uses overlying the aquifer. Describe any } \\
\text { documented water quality issues affecting the aquifer. Do not use } \\
\text { this field to document contaminant point sources. Erample: } \\
\text { Chloride levels in the Dakota Aquifer below Phillips County and } \\
\text { Kirwin Reservoir are } 10,000-20,000 \text { mg/L, which is defined by } \\
\text { the Kansas Corporation Commission as unusable or } \\
\text { mineralized. The pH of the Dakota Aquifer ranges from } 7.5 \text { to } \\
\text { 8.5. Other naturally-occurring constituents of interest in the } \\
\text { aquifer are Fe, Mn, and F. In the confined portion of the } \\
\text { aquifer, reactions with dissolved constituents and sediments } \\
\text { have essentially consumed all dissolved orygen, resulting in a } \\
\text { reducing environment. The reducing environment allows Fe, } \\
\text { Mn, and some other heavy metals to dissolve from the sediments. } \\
\text { Sometimes these waters can have sufficient hydrogen sulfide } \\
\text { content to give a "rotten egg" odor. Ammonium ion levels can be } \\
\text { over } 1 \text { mg/L in the reducing environment. Flow of the aquifer is } \\
\text { from southwest to northeast. The recharge area for the confined } \\
\text { Dakota Aquifer in Kansas is in southeastern Colorado. Beneath } \\
\text { most of the river valleys, the hydraulic head in the Dakota is } \\
\text { higher than the water level in the streams and may be higher } \\
\text { than the land-surface elevation. This suggests that groundwater } \\
\text { in the Dakota may be discharging to streams or to the surface } \\
\text { along the sloping valley sides. In the area of the refuge, the } \\
\text { aquifer is overlain by relatively impervious strata. Recharge } \\
\text { rates in this area of Kansas are very low. It is separated into } \\
\text { upper and lower aquifers by an aquitard within the Kiowa } \\
\text { Formation. }\end{array}$ & Character limit: 2,000 \\
\hline
\end{tabular}


Section 5 - Ground Water Transport Pathways

KTrum NWR
$M \sin M$ eow

Section Nen

Helo

Nenosdectiner of the equifer:

parore saniser

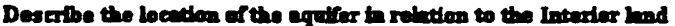

The Daloce Lquifer underlies wot of the vestern

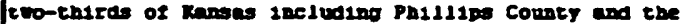
Reservoly/retuoe. Phill1po comet and the

Reservolf/resuoe lie in ene conflaed region of the

Lquiser' range which 10 overlale by the Oppex

Creteceour equiterd.

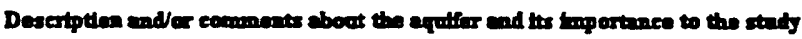

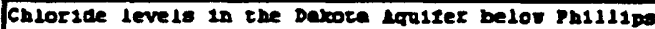

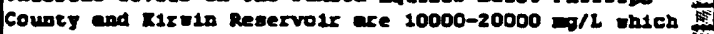

10 desined by the Ranses Corporation Commisilion os

unumble or mineralised. The pl or the

nod1v-blearbosete weer" in tbe cont1ned Dabote

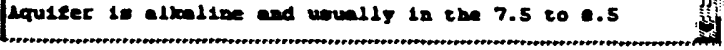

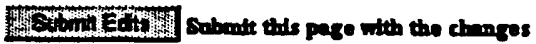

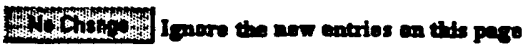

Delete the reard

Figure 5-2. Data entry screen: Transport Pathways - Ground Water. 
Section 5. Guidance for Data Entry and Analysis: Air
Describe the climatological and topographical characteristics of the airshed that could convey contaminants from their sources to the refuge. Predominant surface winds should be described. Information on predominant winds at the refuge area can be obtained from local offices of the National Weather Service. Alternative sources of information on local weather patterns might also include the Department of Agriculture, local pilots associations, or aerial pesticide applicators.

In some cases, particularly in Region 7, the number of weather stations is limited. Frequently, the stations are located considerable distances from refuges. Meteorological data collected at remote locations may not reflect actual wind direction at the refuge. In these cases, alternative data sources regarding predominant local wind directions should be identified (i.e., from refuge staff). Sources, limitations, and gaps of information used in the assessment should be documented.

Currently, the data management system provides a small-scale (coarse) map depicting the extent of default airshed at $150 \mathrm{~km}$ from the boundary of the refuge. This map does not provide information on predominant wind direction. It is recommended that users obtain this information by contacting the nearest National Weather Service "Class-A" meteorological station. Other information that may influence the transport of airborne contaminants is topography and land cover.

Descriptive information is required for winds blowing from the eight cardinal directions (i.e., North, Northeast, East, Southeast, South, Southwest, West, and Northwest). 
Table 5-3. Field descriptions and examples: Transport Pathways - Air.

\begin{tabular}{l|l|l}
\hline \multicolumn{1}{c|}{ Field Name } & \multicolumn{1}{c|}{ Content Guidance/Example } & Data Entry Tips \\
\hline $\begin{array}{l}\text { General } \\
\text { description of } \\
\text { this wind } \\
\text { pattern }\end{array}$ & $\begin{array}{l}\text { Document the wind frequency distribution and percent of time } \\
\text { that the wind blows from the selected direction. Comment on } \\
\text { seasonal influences on the wind direction and speed. Example: } \\
\text { Winds from due south occur about 16\% of the year. While } \\
\text { it is the prevailing wind direction during the summer } \\
\text { months, it occurs throughout the year. Winds from the } \\
\text { south are usually very strong and can be very gusty. Heavy } \\
\text { storms usually result from southerly winds during the } \\
\text { winter months. }\end{array}$ & Character limit: \\
\hline $\begin{array}{l}\text { Comments } \\
\text { about the wind } \\
\text { pattern and its } \\
\text { importance to } \\
\text { the study }\end{array}$ & $\begin{array}{l}\text { Describe considerations (land use, proximity to urban or } \\
\text { agricultural areas) about wind blowing from this direction that } \\
\text { may have particular relevance to the contaminant assessment. } \\
\text { Do not use this field to document contaminant point sources. } \\
\text { Example: Pesticide drift from aerial applications from } \\
\text { surrounding farmland onto the refuge is a good possibility } \\
\text { during the summer months. It is hard to find a } \\
\text { spring/summer day that does not have at least a moderate } \\
\text { southerly breeze. Stockton, Kansas (population } \\
\text { approximately 1,500) is the nearest town south of the } \\
\text { refuge. }\end{array}$ & Character limit: 2,000 \\
\hline
\end{tabular}




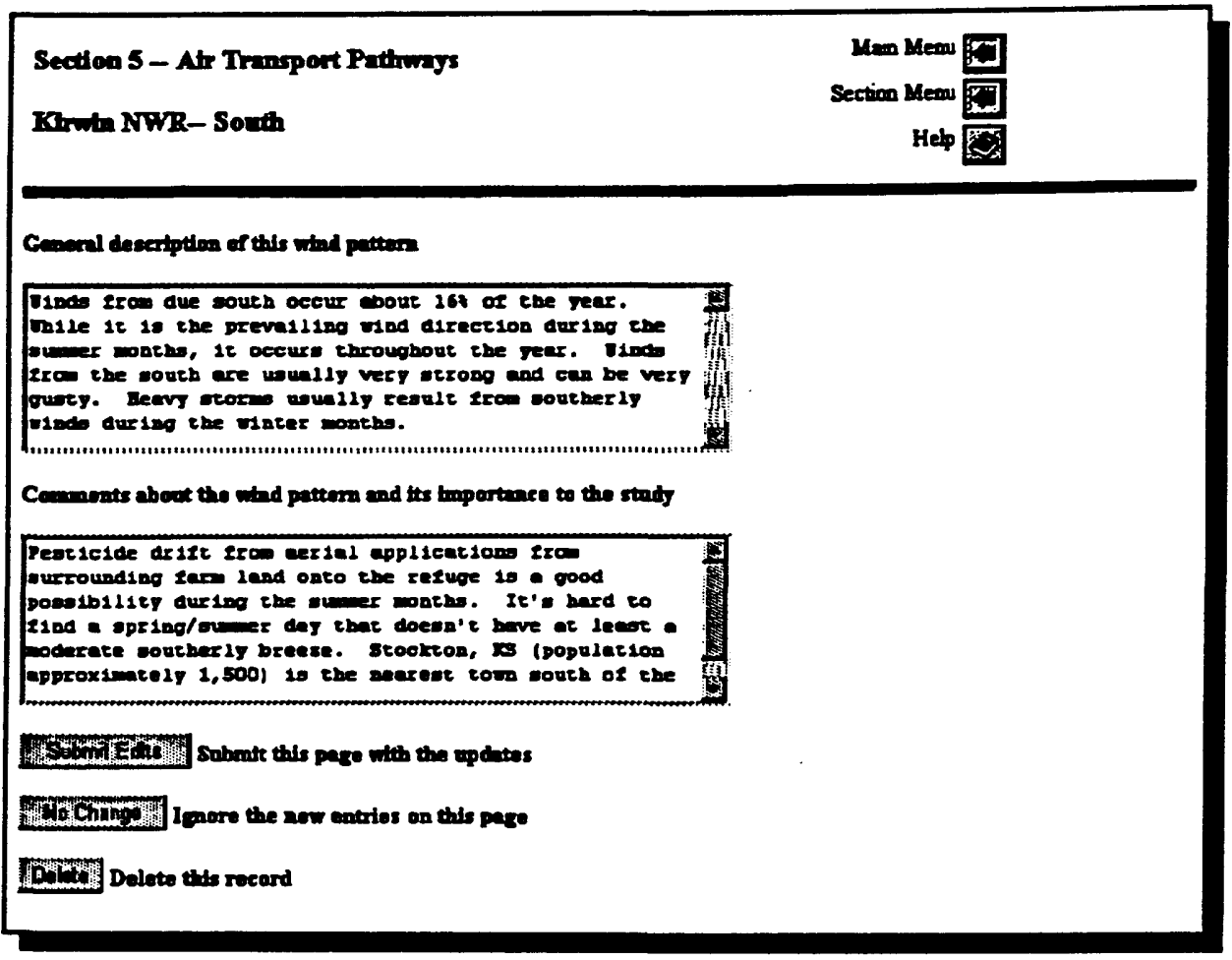

Figure 5-3. Data entry screen: Transport Pathways - Air. 
Section 6. Guidance for Data Entry and Analysis: Biota
The purpose of this subsection is to document information regarding biological vectors that may be transporting appreciable amounts of contaminants to the refuge. This transport mechanism includes instances of migrating organisms which may carry remotely bioaccumulated pesticides or industrial contaminants. While exposure of migratory species may occur in other countries, resident or local organisms can also transport bioaccumulated chemicals in their tissues from contaminated lands adjacent to the refuge. These chemicals might enter the food chain through predator prey interactions or transferred to abiotic media (i.e., soil, sediment, water) upon the death of the animal.

While biotic transport of contaminants should be considered, this transport mechanism is not necessarily applicable for all situations. The assessment of biotic transport should be limited to those species/ assemblages that are likely to carry bioaccumulated contaminants, in sufficient concentrations, to affect the refuge or its biota.

The scope of the biotic transport AOI should generally be limited to local areas unless sufficient information is available to warrant its expansion. Species or assemblages that may constitute a biotic transport mechanism should be selected on the basis of the following considerations:

- tissue concentration and abundance of contaminated biota is sufficient on the refuge to contribute a significant contaminant load to the land or result in significant contaminant entry into the food chain

- organisms have been present on the refuge for a significant period of time

- there are identifiable areas where biota are exposed to contaminants that are likely to bioaccumulate 
Table 5-4. Field descriptions and examples: Transport Pathways - Biota.

\begin{tabular}{l|l|l}
\hline \multicolumn{1}{c|}{ Field Name } & \multicolumn{1}{c|}{ Content Guidance/Example } & Data Entry Tips \\
\hline $\begin{array}{l}\text { Name of the } \\
\text { biota }\end{array}$ & $\begin{array}{l}\text { See considerations mentioned above for selecting species or } \\
\text { assemblages that may act as biological vectors of contaminants. } \\
\text { Example: Bald Eagles. }\end{array}$ & Character limit: 2,000 \\
\hline $\begin{array}{l}\text { Locations on } \\
\text { the Interior land } \\
\text { used exten- } \\
\text { sively by this } \\
\text { species }\end{array}$ & $\begin{array}{l}\text { Identify areas on the refuge that are used extensively by the } \\
\text { suspected species or assemblages. Example: Refuge wide. }\end{array}$ & Character limit: 2,000 \\
$\begin{array}{l}\text { Description } \\
\text { and/or } \\
\text { comments } \\
\text { about this } \\
\text { species and its } \\
\text { importance to } \\
\text { the study }\end{array}$ & $\begin{array}{l}\text { Describe how the contaminants bioaccumulated in the species } \\
\text { or assemblages may impact the habitat or species on the refuge. } \\
\text { Erample: Could feed on contaminated/poisoned food } \\
\text { sources outside of refuge and transport those food sources } \\
\text { to the refuge. Also could bring body burdens of } \\
\text { contaminants to the refuge. }\end{array}$ & Character limit: 2,000 \\
\hline
\end{tabular}


Section 5 - Biotic Trenport Pathwass

Konitin NWR
Men Mesu

Section Menu

Help

Ninen of the blote:

Bald Eagles

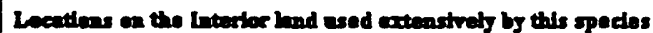

Retuon vide

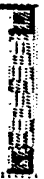

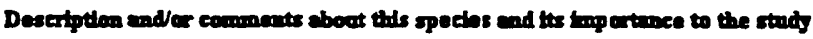

Could read on conceninaced/poluoned rood sources

outende of retuge and tranoport those lood sourcea to

the refuge. 1200 could bring body burdens of

oonteninasts 1 seo refwe.

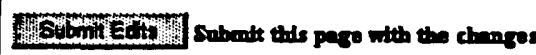

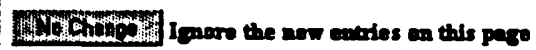

Difolete the recard

Figure 5-4. Data entry screen: Transport Pathways - Biota. 
10101016.

Contaminant S.ourre. 1 inomination

Section 1. Overview
Section 6 of the data management system is used to compile, review, and interpret facility location and contaminant release information for point and nonpoint sources within the AOI for each transport mechanism. The review of point sources within the AOI is facilitated by the operation of the data management system.

Information regarding nonpoint sources must be documented by the Primary Investigator in the "Other Site" subsection.

The level of effort required for this review will vary depending on the scale of the AOI and the number of sources located therein. Occasionally, the number of facilities located in the AOI can be large, particularly when the unit is located in an expansive watershed, or near urban areas. If the number of contaminant sources appears unmanageable, the user might consider reducing the number evaluated. The overall number of facilities can be reduced by using one or both of the following strategies:

(1) reduce the spatial extent of the assessment (see explanation in this Chapter under Section 2 - Database Operation: Refine Selection Option)

(2) evaluate the potential cumulative impact of contaminants released from multiple, but related sources, such as:

- grouping individual farms along a common waterway according to crops grown and likely contaminants released, and

- consolidating sources within an urban area that are likely to release similar contaminants or contaminant classes.

Evaluating risks posed by environmental contaminants involves estimating the likelihood that deleterious ecological effects may occur or are occurring as a result of exposure to one or more pollutants. The potential that a chemical will cause an adverse effect on individuals or populations depends on the exposure concentration and duration, the inherent toxicity of the agent, and the sensitivity of the receptor(s). Given the apparent simplicity of this statement, the fact remains, estimating ecological risks that environmental contaminants pose to biological organisms in real-world scenarios is a daunting task. The challenge is to predict the potential effect of a bewildering array of chemicals, released to multiple media, on a diverse combination of plant and animal species. The relative scarcity of laboratory toxicity studies for most plant/animal/contaminant interactions compounds the difficulty of the task. The possibility that chemicals released in mixtures may act synergistically or antagonistically further 
complicates the ability to anticipate the response of individual organisms or populations. The end result of these considerations is that making reliable predictions about the potential effects of complex mixtures on populations and ecosystems is rarely achieved.

Notwithstanding this caution, the CAP provides a framework for making useful, screening-level estimates of risks posed by environmental contaminants. Once the appropriate information is compiled, consideration should be given to two significant issues: magnitude of exposure and toxicity. To address the issue of exposure, the Primary Investigator must decide, based on the available data, whether released chemicals are reaching the refuge. Secondly, given the inherent toxicity of the chemicals, the Primary Investigator must decide if the concentrations reaching the refuge are sufficient to produce deleterious effects.

Factors Influencing Exposure

The likelihood that a released chemical will reach the refuge by abiotic transport mechanisms and thereby pose an exposure risk, depends on a number of physical and chemical factors. In the case of contaminants in surface water pathways, these factors include the following considerations:

- magnitude and proximity of release

- residence time prior to reaching the refuge

- dilution by receiving waters and adjoining tributaries

- relative significance compared with other sources

- partitioning of the contaminant (dissolved vs. particulatebound)

- presence of sediment sinks (lakes, reservoirs) between the source and the refuge

- biotic uptake and transformation

- water temperature, $\mathrm{pH}$, and hardness

- photolytic and biological chemical degradation

The likelihood that airborne contaminants reach the refuge are affected by the following factors:

- volatility

- phase (gas, aerosol, particulate)

- atmospheric transformations

- dilution

- predominant wind and weather patterns

- sorption

- topography 
The possibility that contaminants are transported to the refuge by biotic vectors is influenced by several factors, including the chemical's ability to bioconcentrate, toxicity, and the number of contaminated organisms reaching the unit.

A number of references that provide insight into the physical/chemical characteristics of a variety of chemicals that influence their environmental persistence, mobility, and fate are available. A wealth of information is available online that describes chemical fate and effects. Descriptions of the EPA databases accessed by the CAP data management system, and potentially valuable websites containing information on chemical fate and effects, are provided in Appendix B. Information contained in the fate and effect websites can help the Primary Investigator assess whether the chemicals are likely to be transported from their sources to the refuge and whether they are likely to cause an effect.

Factors Influencing Toxicity

General Recommendations

Assuming contaminants reach the refuge, their capacity to have deleterious effects on biological organisms depends on the concentration, duration of exposure, and toxicity. Biological impacts can result from short exposure to small quantities of highly poisonous chemicals or from long exposure to moderate concentrations of mildly toxic agents. Sensitivity to contaminants varies depending on the route of exposure and life stage of the exposed organism. To the extent possible, the physical/chemical factors listed above which influence a contaminants' likelihood of reaching the refuge, along with its toxicity to potentially sensitive species, should be taken into account when determining whether released chemicals are likely to cause an effect.

In many cases, a large number of contaminant sources will be located in the AOIs. The sources are likely to release complex mixtures of contaminants. The Primary Investigator may need to make a decision, based on professional judgement, to focus the assessment on a limited number of high priority sources and contaminants. The challenge is deciding which sources pose the greatest risks to the refuge. In general, the guiding principle in such a decision is to evaluate proximal sources that report releases of:

- $\quad$ large quantities (i.e., thousands to millions of pounds annually) of low to moderately toxic, contaminants of limited persistence, and

- $\quad$ small to moderate quantities (i.e., hundreds to thousands of pounds annually) of highly toxic and persistent contaminants. 
This approach tends to disregard remote sources or sources releasing small amounts of potentially toxic contaminants. The prioritization scheme, and its potential limitations, adopted by the Primary Investigator should be described in the Narrative Report of Contaminant Issues of the data management system.

\section{Section 2. Data Management System Operation}

\section{Selecting and Reviewing Facility Information}

\author{
Eliminating and \\ Retaining Facilities
}

As described in Part I: Chapter 2, the data management system uploads administrative and contaminant information for regulated facilities located within each AOI from five on-line EPA databases. The system groups the facilities according to the database from which the information is derived.

In addition to retrieving information from online databases, the system also provides a framework for cataloging user-defined, point and nonpoint contaminant sources. To enter information on known sites that are not reported in the online databases, or to document suspected nonpoint sources, users should select the hypertext link titled "Add Other/User Defined Sites (Including Nonpoint Sources)."

To review facility information, select the database of interest by clicking on the database's name listed in the Main Menu. After selecting a database, the names of facilities located within the AOI are listed on a Record Selection Menu. At the start of an assessment, all site names are listed under the category "Facilities Not Reviewed." Facility names are arranged alphabetically under three distance classifications, "Sites within $10 \mathrm{~km}$," "Sites from 10 to $30 \mathrm{~km}$," and "Sites over $30 \mathrm{~km}$." Administrative and release information can be viewed by clicking on the facility of interest.

The data management system gives users the option to retain information for facilities of concern or eliminate irrelevant sites from further consideration. To eliminate a site, click the button labeled "Eliminate" located at the bottom of each facility record. Once the site is eliminated, the name of the facility is moved to the category "Facilities Reviewed and Eliminated from Analysis." Information for the facility does not appear on subsequent report outputs.

Sites that are eligible for elimination include those that:

- are located far enough from the refuge that released contaminants are unlikely to reach the unit

- are known to have been closed

- are known to be located outside the AOI

- release exceedingly small amounts of marginally toxic chemicals 
Summary of Contaminant Sites

Contaminant Sites Summarized by Transport Pathway

Internal System Links

Caution: EPA Contaminant Source Coordinates
The system retains information for all uploaded sites unless the user specifically designates a facility for elimination. Once facility information is reviewed, evaluated, and determined to be relevant to the assessment, the user saves pertinent information on the record by clicking the button labeled "Submit" at the bottom of the facility record. Once the record is submitted, the data management system moves the name of the facility to the "Summary of Contaminant Sites" menu.

The hypertext link titled "Summary of Contaminant Sites" provides a hypertext menu of all facilities or user-entered sources reviewed and retained for the analysis. The list is organized according to the database from which the facility information was derived. In addition, the list displays the names of user-entered facilities or areas. At the beginning of an assessment, this list will be empty. However, as the assessment of site information proceeds, the list will lengthen and reflect the names of reviewed and retained facilities and user-defined contaminant release areas. To review or edit site records, click on the hypertext "Summary of Contaminant Sites." Then select the record of interest from the list.

The hypertext link titled "Contaminant Sites Summarized by Transport Pathway" provides a summary of contaminant sites organized by transport pathway. Unlike the "Summary of Contaminated Sites" link, this list does not provide direct links to the displayed records. The list of transport pathways is derived from user input and from the data field titled "Receiving Water" contained on the PCS/NPDES and TRI facility records.

The system provides a picklist of individuals for each facility or user-defined record. The picklist is derived from the names of contacts entered in Section 2: Background Information - Contacts. The system allows users to enter new contact information on the facility or user-defined records. Names added here are in turn appended to the Contact list in Section 2: Background Information - Contacts. The database provides picklists for contaminant transport pathways on each facility or user-defined record. These picklists are derived from information entered in Section 5: Transport Pathways. In the case of surface water pathways, the names are also derived from the "Receiving Water" field retrieved from the PCS/NPDES and TRI databases.

The system uses EPA-supplied coordinated data to identify reporting facilities located within the AOIs at the beginning of a study. The system also uses these data to calculate the distance and 
direction of the sources from the refuge. Because EPA relies on the reporting facility to provide accurate coordinate information, EPA cannot guarantee the validity of the information. The data management system performs a cross-check on the EPA-supplied coordinate data to verify whether they lie within the counties or zip codes bounded by the defined AOI information. If the cross-check is valid, the EPA-supplied coordinates are presumed to be accurate. Where the EPA databases do not provide coordinate data, or the cross-check operation indicates an invalid coordinate, the system assigns latitude and longitude readings based on the centroid of the zip code or for the county in which the facility's street address is located. As a result of this operation, multiple facilities may appear clustered on points that represent approximated locations. The distance and direction information from the refuge presented in the system for approximated locations will not correspond to the actual locations of the facilities. Where possible, the user should note the discrepancy in the comment box associated with the facility. When location information appears suspect, it may be advisable to contact the facility to confirm its actual whereabouts.

Refine Selection Option

CERCLIS Hypertext Links to EPA Databases
The system provides an option that allows the user to restrict or enlarge the spatial extent of the area used to query EPA databases. This operation is similar to the "Upload Part" option described in Part I - Chapter 2 of this guide. To use this option, click on the "Refine Selection Set" hypertext link at the bottom of the record selection screen for each EPA data set. The system displays a text box for the user to enter the approximate size of the area to be searched. Once the descriptive information is entered into the box, the user clicks the button labeled "Refine Data." This notifies the system's administrators of the request to refine the upload area. The administrators translate the area into a query, which is then sent to the EPA database of interest. The refined data set is typically uploaded within 24 hours of the request.

The system provides two hypertext links to information derived from the EPA CERCLIS database. One link provides information concerning the Record of Decision (ROD). The second link displays the EPA generated Fact Sheet for the site. If the hypertext link reads "Available," the system contains the information from the EPA database. If the hypertext link reads "Unavailable," there is no data for the site in the EPA data base. Information contained in the system is uploaded from the EPA database at the initiation of the CAP. 


\section{Section 3. Guidance for Data Entry and Analysis: Contaminant Source Information}

Table 6-1. Field descriptions and examples: Contaminant Source Information - TRI Sites.

\begin{tabular}{l|l|l}
\hline Field Name & \multicolumn{1}{|c|}{ Content Guidance/Erample } & \multicolumn{1}{|c}{ Data Entry Tips } \\
\hline Facility name & $\begin{array}{l}\text { Name of facility and database specific identification number. } \\
\text { Example: ABIMIBI CONSOLIDATED SALES - } \\
\text { 98388BSCSC4302C. }\end{array}$ & $\begin{array}{l}\text { Database query results. } \\
\text { Read only. }\end{array}$ \\
\hline Facility ID & $\begin{array}{l}\text { This field contains the unique identification number assigned by the } \\
\text { TRI database for the facility. The format ZZZZZ-NNNNNSSSSS, } \\
\text { where ZZZZZ = zip code, NNNNN = first 5 consonants of the } \\
\text { name, and SSSSS = first 5 non-blank non-special characters in the } \\
\text { street address. Erample: 98388BSCSC4302C. }\end{array}$ & $\begin{array}{l}\text { Database query results. } \\
\text { Read only. }\end{array}$ \\
\hline Address & $\begin{array}{l}\text { This field contains the first line of the street name in the address of } \\
\text { the reporting facility. Erample: 4302 CHAMBERS CREEK RD. }\end{array}$ & $\begin{array}{l}\text { Database query results. } \\
\text { Read only. }\end{array}$ \\
\hline City & $\begin{array}{l}\text { This field contains the name of the city in which the reporting } \\
\text { facility is located. Erample: STEHACOOM. }\end{array}$ & $\begin{array}{l}\text { Database query results. } \\
\text { Read only. }\end{array}$ \\
\hline State & $\begin{array}{l}\text { This field contains the name of the state in which the reporting } \\
\text { facility is located. Erample: WA. }\end{array}$ & $\begin{array}{l}\text { Database query results. } \\
\text { Read only. }\end{array}$ \\
\hline Zip code & $\begin{array}{l}\text { This field contains the zip code in which the reporting facility is } \\
\text { located. Erample: 983881528. }\end{array}$ & $\begin{array}{l}\text { Database query results. } \\
\text { Read only. }\end{array}$ \\
\hline Plant status & $\begin{array}{l}\text { This field contains the operating status of the facility. Erample: No } \\
\text { data. }\end{array}$ & $\begin{array}{l}\text { Database query results. } \\
\text { Read only. }\end{array}$ \\
\hline Plant description & $\begin{array}{l}\text { This field contains the description for the Standard Industrial } \\
\text { Classification (SIC) Code, which describes the type of } \\
\text { activities performed at the facility. Erample: Paper Mills. }\end{array}$ & $\begin{array}{l}\text { Database query results. } \\
\text { Read only. }\end{array}$ \\
\hline
\end{tabular}

TRI Facility Location - Relative Location - Derived from EPA Data

\begin{tabular}{l|l|l}
\hline $\begin{array}{l}\text { Direction from } \\
\text { centroid of DOI } \\
\text { land }\end{array}$ & $\begin{array}{l}\text { This field contains the direction of the facility relative to the refuge. } \\
\text { It is calculated by the data management system. Example: } \\
\text { Northeast. }\end{array}$ & $\begin{array}{l}\text { Calculated direction. } \\
\text { Read only. }\end{array}$ \\
\hline $\begin{array}{l}\text { Distance from } \\
\text { centroid of DOI } \\
\text { land }(\mathrm{km})\end{array}$ & $\begin{array}{l}\text { This field contains the distance }(\mathrm{km}) \text { of the facility to the refuge. It } \\
\text { is calculated by the data management system. Example: 30. }\end{array}$ & $\begin{array}{l}\text { Calculated distance. } \\
\text { Read only. }\end{array}$ \\
\hline
\end{tabular}

TRI Facility Location - Latitude

\begin{tabular}{l|l|l}
\hline Degrees & $\begin{array}{l}\text { Distance of the facility north or south of the equator, measured on a } \\
\text { meridian, expressed in degrees. Example: } 47 .\end{array}$ & $\begin{array}{l}\text { Database query results. } \\
\text { Can be user-edited. }\end{array}$ \\
\hline Minutes & $\begin{array}{l}\text { Distance of facility north or south of the equator, measured on a } \\
\text { meridian, expressed in minutes. Example: 11. }\end{array}$ & $\begin{array}{l}\text { Database query results. } \\
\text { Can be user-edited. }\end{array}$ \\
\hline Seconds & $\begin{array}{l}\text { Distance of the facility north or south of the equator, measured on a } \\
\text { meridian, expressed in seconds. Example: 8. }\end{array}$ & $\begin{array}{l}\text { Database query results. } \\
\text { Can be user-edited. }\end{array}$ \\
\hline
\end{tabular}




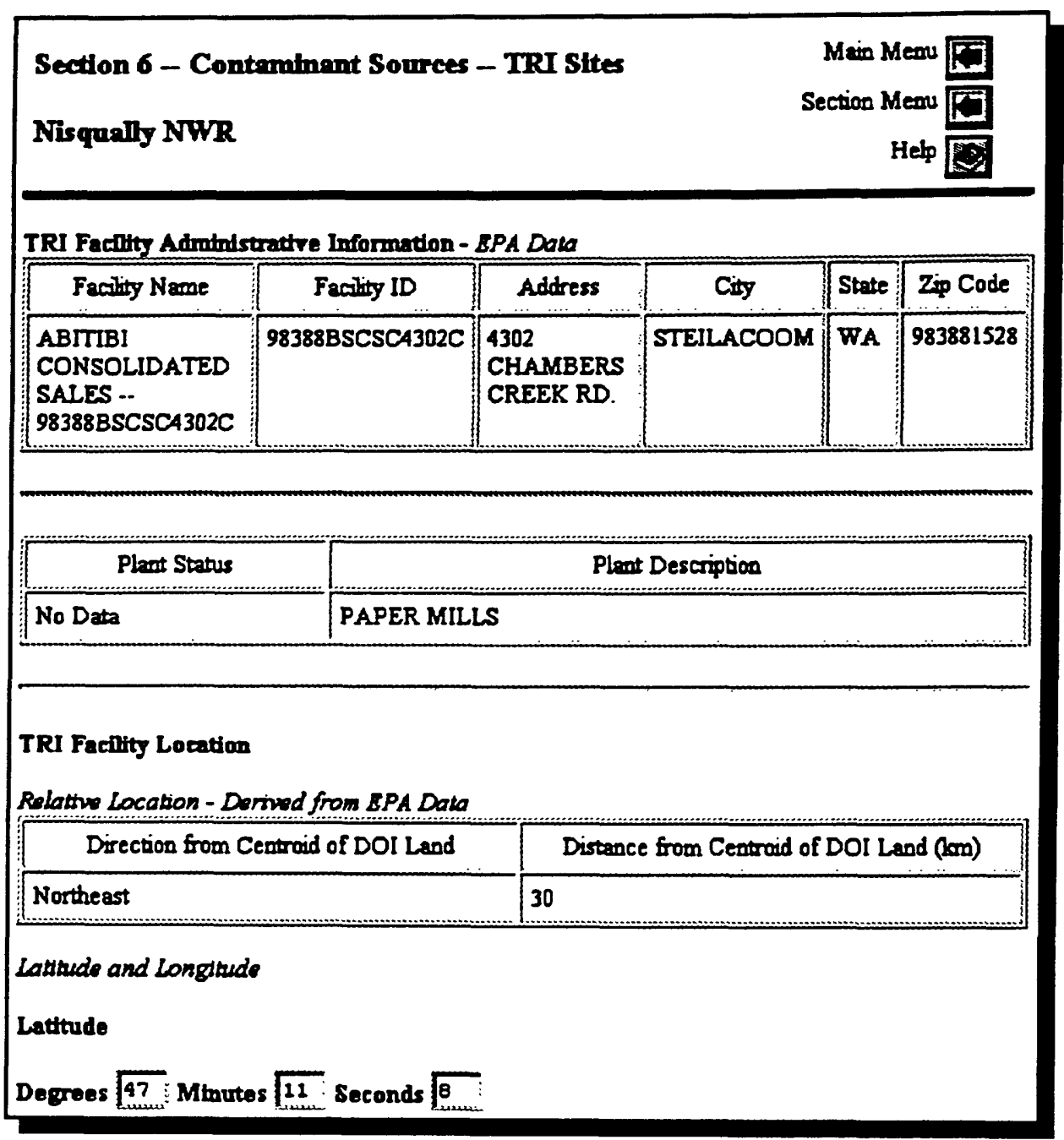

Figure 6-1. Data entry screen: Contaminant Source Information - TRI Sites. 
Table 6-1. Continued.

\begin{tabular}{|c|c|c|}
\hline Field Name & Content Guidance/Erample & Data Entry Tips \\
\hline \multicolumn{3}{|c|}{ TRI Facility Location - Longitude } \\
\hline Degrees & $\begin{array}{l}\text { The location of the facility in reference to the prime meridian } \\
\text { expressed in degrees. Example: }-122 \text {. }\end{array}$ & $\begin{array}{l}\text { Database query results. } \\
\left({ }^{\mu-"} \text { in N. America) }\right. \\
\text { Can be user-edited. }\end{array}$ \\
\hline Minutes & $\begin{array}{l}\text { The location of the facility in reference to the prime meridian } \\
\text { expressed in minutes. Example: } 35 \text {. }\end{array}$ & $\begin{array}{l}\text { Database query results. } \\
\text { Can be user-edited. }\end{array}$ \\
\hline Seconds & $\begin{array}{l}\text { The location of the facility in reference to the prime meridian } \\
\text { expressed in seconds. Example: } 5 \text {. }\end{array}$ & $\begin{array}{l}\text { Database query results. } \\
\text { Can be user-edited. }\end{array}$ \\
\hline $\begin{array}{l}\text { Is this location } \\
\text { ON or OFF } \\
\text { Interior lands? }\end{array}$ & $\begin{array}{l}\text { This field is used to classify facility as being located within or } \\
\text { outside of the refuge boundary. Example: Off. }\end{array}$ & $\begin{array}{l}\text { Radio button. One } \\
\text { selection allowed. }\end{array}$ \\
\hline \multicolumn{3}{|c|}{ TRI Reported Water Releases - EPA Data } \\
\hline $\begin{array}{l}\text { Chemicals/ } \\
\text { compounds }\end{array}$ & $\begin{array}{l}\text { This field contains the names of chemicals or chemical categories } \\
\text { reported released from the facility. The names are derived from } \\
\text { Section } 372.45 \text { of Section } 313 \text { of the Emergency Planning and } \\
\text { Community Right-to-Know Act (EPCRA). Erample: No data. }\end{array}$ & $\begin{array}{l}\text { Database query results. } \\
\text { Read only. }\end{array}$ \\
\hline Receiving water & $\begin{array}{l}\text { This field contains the name of each receiving stream or water body } \\
\text { into which the chemicals are directly discharged, as it appears on } \\
\text { the NPDES permit for the facility. Example: No data. }\end{array}$ & $\begin{array}{l}\text { Database query results. } \\
\text { Read only. }\end{array}$ \\
\hline Release amount & $\begin{array}{l}\text { This field contains the amount (lbs) of chemicals released from the } \\
\text { plant estimated as a range, the midpoint of the range was used in } \\
\text { these calculations. "No data" indicates no releases were reported for } \\
\text { the media for the given reporting year. Example: No data. }\end{array}$ & $\begin{array}{l}\text { Database query results. } \\
\text { Read only. }\end{array}$ \\
\hline \multicolumn{3}{|c|}{ TRI Reported Air Releases - EPA Data } \\
\hline $\begin{array}{l}\text { Chemicals/ } \\
\text { compounds }\end{array}$ & $\begin{array}{l}\text { This field contains the names of chemicals or chemical categories } \\
\text { reported released from the facility. The names are derived from } \\
\text { Section } 372.45 \text { of Section } 313 \text { of the Emergency Planning \& } \\
\text { Community Right-To-Know Act (EPCRA) } \\
\text { Example: METHANOL. }\end{array}$ & $\begin{array}{l}\text { Database query results. } \\
\text { Read only. }\end{array}$ \\
\hline Media & $\begin{array}{l}\text { Eugitive emissions (FUG) are those releases from equipment leaks } \\
\text { (valves, seals, connections), evaporative losses from surface } \\
\text { impoundments and spills; releases from building ventilation } \\
\text { systems; and any other fugitive or nonpoint air emissions. Stack } \\
\text { emissions (STACK) are releases that occur through stacks, vents, } \\
\text { ducts, pipes, or other confined air streams, as well as storage tank } \\
\text { emissions and air releases from air pollution control equipment. } \\
\text { Example: FUG. }\end{array}$ & $\begin{array}{l}\text { Database query results. } \\
\text { Read only. }\end{array}$ \\
\hline Release amount & $\begin{array}{l}\text { This field contains the amount (lbs) of chemicals released from the } \\
\text { plant, annually, estimated as a range, the mid-point of the range is } \\
\text { used in calculations. "No data" indicates no releases were reported } \\
\text { for the media for the given reporting year. Example: } 13000 \text { lbs. }\end{array}$ & $\begin{array}{l}\text { Database query results. } \\
\text { Read only. }\end{array}$ \\
\hline $\begin{array}{l}\text { Category(s) } \\
\text { where contam- } \\
\text { inant SOURCE } \\
\text { best fits? }\end{array}$ & $\begin{array}{l}\text { Use this picklist to categorize the type(s) of contaminant source } \\
\text { (point and nonpoint) that best describes the facility. Example: Pulp } \\
\text { and Paper Mills. }\end{array}$ & $\begin{array}{l}\text { Picklist: } 70 \text { selections. } \\
\text { Multiple selections } \\
\text { allowed. Defaults to } \\
\text { "Not Applicable". }\end{array}$ \\
\hline
\end{tabular}


Lonottonde

Deerees 122 Minutes 35 Secunds 5

Is this location ON or OFF Lutrior lands?

on

or

TRI Reported Water Roleases - EPA Data

\begin{tabular}{|l|l|l|}
\hline Chemicals/Compounds & Receiving Water & $\begin{array}{l}\text { Release } \\
\text { Amount }\end{array}$ \\
\hline No Data & No Data & No Data \\
\hline
\end{tabular}

TRI Reported Atr Releases - EPA Data

\begin{tabular}{|l|l|l|}
\hline \multicolumn{1}{c|}{ Chemicals/Compounds } & Media & Release Amount \\
\hline METHLANOL & FUG & $13000 \mathrm{lbs}$ \\
\hline METHLANOL & FUG & $700 \mathrm{lbs}$ \\
\hline METHLANOL & STK & $750 \mathrm{lbs}$ \\
\hline METHLNOL & STK & $9300 \mathrm{lbs}$ \\
\hline
\end{tabular}

Category(s) where this contaminant SOURCE best fits?

Fulp and naner mills

Accident - spills

Adhesives and sealents manuf.

Agricultural + aerial sprey

Anticultural - oraimuater

Figure 6-1. Continued. 
Table 6-1. Concluded.

\begin{tabular}{l|l|l}
\hline \multicolumn{1}{c|}{ Field Name } & \multicolumn{1}{|c|}{ Content Guidance/Example } & \multicolumn{1}{c}{ Data Entry Tips } \\
\hline $\begin{array}{l}\text { Contaminant } \\
\text { classifications } \\
\text { linked to this } \\
\text { source }\end{array}$ & $\begin{array}{l}\text { Use this picklist to document the types of contaminant classes that } \\
\text { are released from the facility. Example: Pulp and Paper Mills. }\end{array}$ & $\begin{array}{l}\text { Picklist: 64 selections. } \\
\text { Multiple selections } \\
\text { allowed. Defaults to "No } \\
\text { Selection" }\end{array}$ \\
\hline
\end{tabular}

Pathways That Allow Contaminant(s) to Reach the Trust Area

\begin{tabular}{|c|c|c|}
\hline Groundwater & $\begin{array}{l}\text { Pathways described in Section } 5 \text { are presented in this record as a } \\
\text { picklist. Select the pathway(s) by which contaminants released from } \\
\text { the facility are conducted to the refuge. Example: None } \\
\text { highlighted. }\end{array}$ & $\begin{array}{l}\text { Picklist: Derived from } \\
\text { Section 5: Pathways. } \\
\text { Multiple selections } \\
\text { allowed. Defaults to "No } \\
\text { Selection." }\end{array}$ \\
\hline Air & $\begin{array}{l}\text { Pathways described in Section } 5 \text { are presented in this record as a } \\
\text { picklist. Select the pathway(s) by which contaminants released from } \\
\text { the facility are conducted to the refuge. Example: "Northeast" } \\
\text { highlighted. }\end{array}$ & $\begin{array}{l}\text { Picklist: Derived from } \\
\text { Section 5: Pathways. } \\
\text { Multiple selections } \\
\text { allowed. Defaults to "No } \\
\text { Selection". } \\
\end{array}$ \\
\hline Biotic & $\begin{array}{l}\text { Potential biological contaminant vectors from Section 5: Pathways } \\
\text { are listed here. Select those organisms that may transport } \\
\text { contaminants from the site to the refuge. Example: No species } \\
\text { listed in Section 5. }\end{array}$ & $\begin{array}{l}\text { Picklist. Multiple species } \\
\text { can be selected. Defaults } \\
\text { to "No Selection". }\end{array}$ \\
\hline Comments & $\begin{array}{l}\text { Describe characteristics about this facility that may have particular } \\
\text { relevance to the contaminant assessment. Enter any ancillary } \\
\text { information that is not covered adequately by the picklist of } \\
\text { contaminants. Comments may include water or air quality } \\
\text { parameters that are likely to be impacted by the operation of the } \\
\text { facility. Erample: Reported air releases of methanol is not likely } \\
\text { to cause significant environmental damage. However, bleached } \\
\text { paper and pulp mill operations are suspected to release } \\
\text { chlorinated byproducts including dioxins and furans which can } \\
\text { bioaccumulate in aquatic and avian species. }\end{array}$ & Character limit: 2,000 \\
\hline $\begin{array}{l}\text { Contacts linked } \\
\text { to this site }\end{array}$ & $\begin{array}{l}\text { Provides a picklist of contacts previously entered. Select name of } \\
\text { individual with particular knowledge about the source. If the name } \\
\text { is not presented in the picklist, enter it in the fields below. Names } \\
\text { from the picklist and added names can be submitted concurrently. } \\
\text { Example: None selected. }\end{array}$ & $\begin{array}{l}\text { Picklist: Derived from } \\
\text { Section 2: Contacts. } \\
\text { Multiple selections } \\
\text { allowed. Defaults to "No } \\
\text { Selection". }\end{array}$ \\
\hline \multirow[t]{2}{*}{ Add new contact } & Use this field to enter the surname of contact. Example: None. & Character limit: 40 \\
\hline & Use this field to enter the last name of contact. Example: None. & Character limit: 40 \\
\hline
\end{tabular}




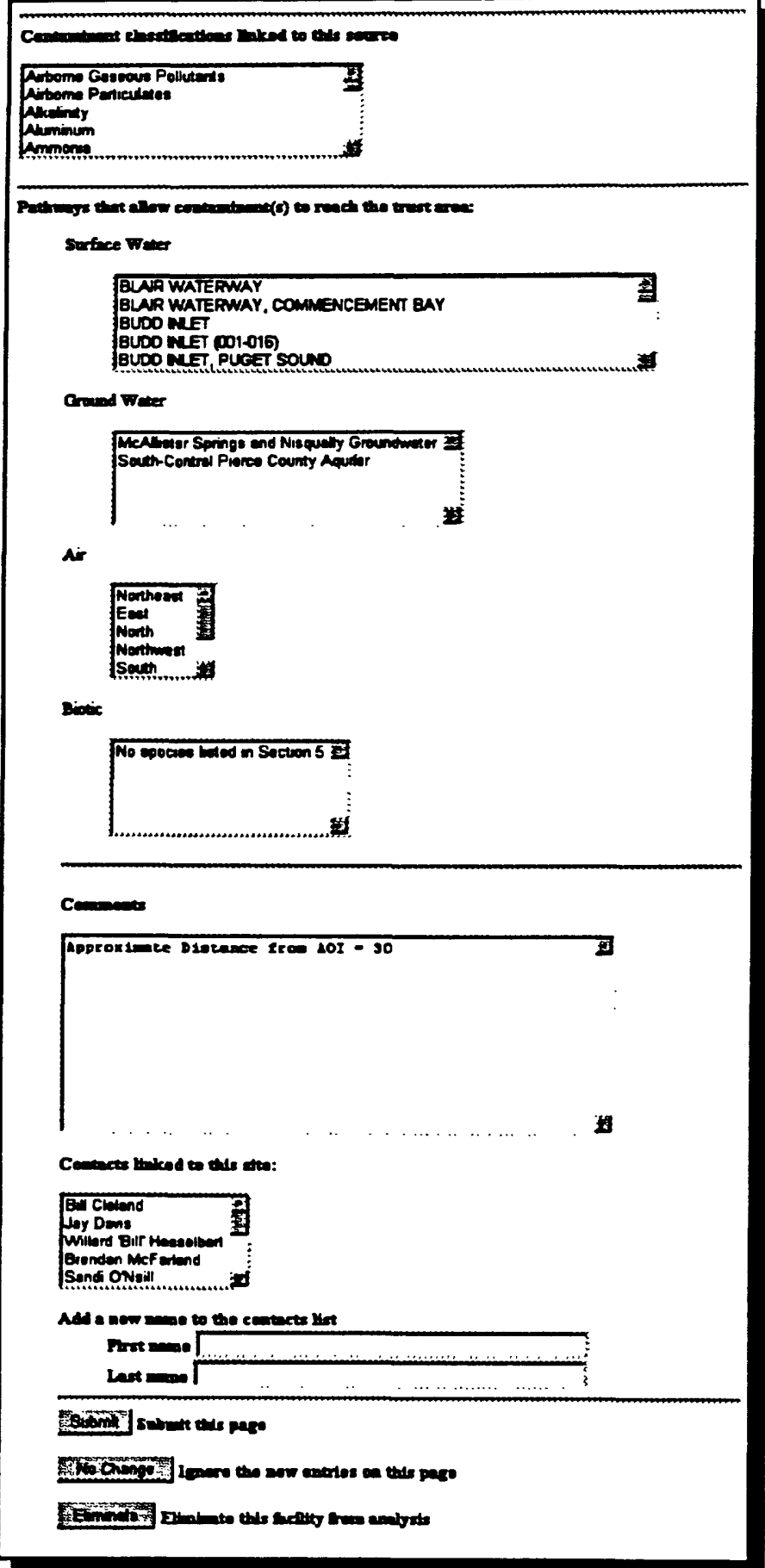

Figure 6-1. Concluded. 
Table 6-2. Field descriptions and examples: Contaminant Source Information - PCS/NPDES Sites.

\begin{tabular}{|c|c|c|}
\hline Field Name & Content Guidance/Erample & Data Entry Tips \\
\hline Facility Name & $\begin{array}{l}\text { Name of facility and database specific identification number. } \\
\text { Example: PIERCE CNTY CEAMBERS CREEK STP - } \\
\text { WA0039624. }\end{array}$ & $\begin{array}{l}\text { Database query results. } \\
\text { Read only. }\end{array}$ \\
\hline Facility ID & $\begin{array}{l}\text { This field contains the unique identification assigned by the } \\
\text { database. Example: WA0039624. }\end{array}$ & $\begin{array}{l}\text { Database query results. } \\
\text { Read only. }\end{array}$ \\
\hline Address & $\begin{array}{l}\text { This field contains the firs line of the street name in the address of } \\
\text { the facility. Example: 10311 CHAMBERS CREEK ROAD. }\end{array}$ & $\begin{array}{l}\text { Database query results. } \\
\text { Read only. }\end{array}$ \\
\hline City & $\begin{array}{l}\text { This field contains the city in which the facility is located. } \\
\text { Erample: TACOMA. }\end{array}$ & $\begin{array}{l}\text { Database query results. } \\
\text { Read only. }\end{array}$ \\
\hline State & $\begin{array}{l}\text { This field contains the state in which the facility is located. } \\
\text { Example: WA. }\end{array}$ & $\begin{array}{l}\text { Database query results. } \\
\text { Read only. } \\
\end{array}$ \\
\hline Zip Code & $\begin{array}{l}\text { This field contains the zip code in which the facility is located. } \\
\text { Example: } 98467 .\end{array}$ & $\begin{array}{l}\text { Database query results. } \\
\text { Read only. }\end{array}$ \\
\hline Plant Status & $\begin{array}{l}\text { This field contains the operating status of the facility. Example: } \\
\text { Operating. }\end{array}$ & $\begin{array}{l}\text { Database query results. } \\
\text { Read only. }\end{array}$ \\
\hline $\begin{array}{l}\text { Plant } \\
\text { Description }\end{array}$ & $\begin{array}{l}\text { This field contains the description for the SIC code which describes } \\
\text { the type of activity at the site. Erample: SEWERAGE SYSTEMS }\end{array}$ & $\begin{array}{l}\text { Database query results. } \\
\text { Read only. }\end{array}$ \\
\hline \multicolumn{3}{|c|}{ PCS/NPDES Facility Location - Relative Location - Derived from EPA Data } \\
\hline $\begin{array}{l}\text { Direction from } \\
\text { Centroid of DOI } \\
\text { Land }\end{array}$ & $\begin{array}{l}\text { This field contains the direction of the facility relative to the refuge. } \\
\text { It is calculated by the data management system. } \\
\text { Erample: Northeast. }\end{array}$ & $\begin{array}{l}\text { Calculated direction. } \\
\text { Read only. }\end{array}$ \\
\hline $\begin{array}{l}\text { Distance from } \\
\text { Centroid of DOI } \\
\text { Land (km) } \\
\end{array}$ & $\begin{array}{l}\text { This field contains the distance }(\mathrm{km}) \text { of the facility to the refuge. It } \\
\text { is calculated by the data management system. Example: } 30 \text {. }\end{array}$ & $\begin{array}{l}\text { Calculated distance. } \\
\text { Read only. }\end{array}$ \\
\hline \multicolumn{3}{|c|}{ PCS/NPDES Facility Location - Latitude } \\
\hline Degrees & $\begin{array}{l}\text { Distance of the facility north or south of the equator, measured on a } \\
\text { meridian, expressed in degrees. Example: } 47 \text {. }\end{array}$ & $\begin{array}{l}\text { Character limit: } 2 . \\
\text { Database query results. } \\
\text { Can be user-edited. }\end{array}$ \\
\hline Minutes & $\begin{array}{l}\text { Distance of the facility north or south of the equator, measured on a } \\
\text { meridian, expressed in minutes. Example: } 11 \text {. }\end{array}$ & $\begin{array}{l}\text { Character limit: } 2 . \\
\text { Database query results. } \\
\text { Can be user-edited. } \\
\end{array}$ \\
\hline Seconds & $\begin{array}{l}\text { Distance of the facility north or south of the equator, measured on a } \\
\text { meridian, expressed in seconds. Example: } 38 \text {. }\end{array}$ & $\begin{array}{l}\text { Character limit: } 2 \text {. } \\
\text { Database query results. } \\
\text { Can be user-edited. }\end{array}$ \\
\hline \multicolumn{3}{|c|}{ PCS/NPDES Facility Location - Longitude } \\
\hline Degrees & $\begin{array}{l}\text { The location of the facility in reference to the prime meridian } \\
\text { expressed in degrees. Example: }-\mathbf{1 2 2} \text {. }\end{array}$ & $\begin{array}{l}\text { Character limit: } 3 . \\
\text { ("-" in N. America) } \\
\text { Database query results. } \\
\text { Can be user-edited. } \\
\end{array}$ \\
\hline Minutes & $\begin{array}{l}\text { The location of the facility in reference to the prime meridian } \\
\text { expressed in minutes. Example: } 34 \text {. }\end{array}$ & $\begin{array}{l}\text { Character limit: } 2 \text {. } \\
\text { Database query results. } \\
\text { Can be user-edited. } \\
\end{array}$ \\
\hline Seconds & $\begin{array}{l}\text { The location of the facility in reference to the prime meridian } \\
\text { expressed in seconds. Erample: } 28 \text {. }\end{array}$ & $\begin{array}{l}\text { Character limit: } 2 . \\
\text { Database query results. } \\
\text { Can be user-edited. }\end{array}$ \\
\hline $\begin{array}{l}\text { Is this location } \\
\text { ON or OFF } \\
\text { Interior lands? }\end{array}$ & $\begin{array}{l}\text { Classify facility as being located within the refuge boundary or } \\
\text { outside of the boundary. Example: Off. }\end{array}$ & $\begin{array}{l}\text { Radio button. One } \\
\text { selection allowed. }\end{array}$ \\
\hline
\end{tabular}




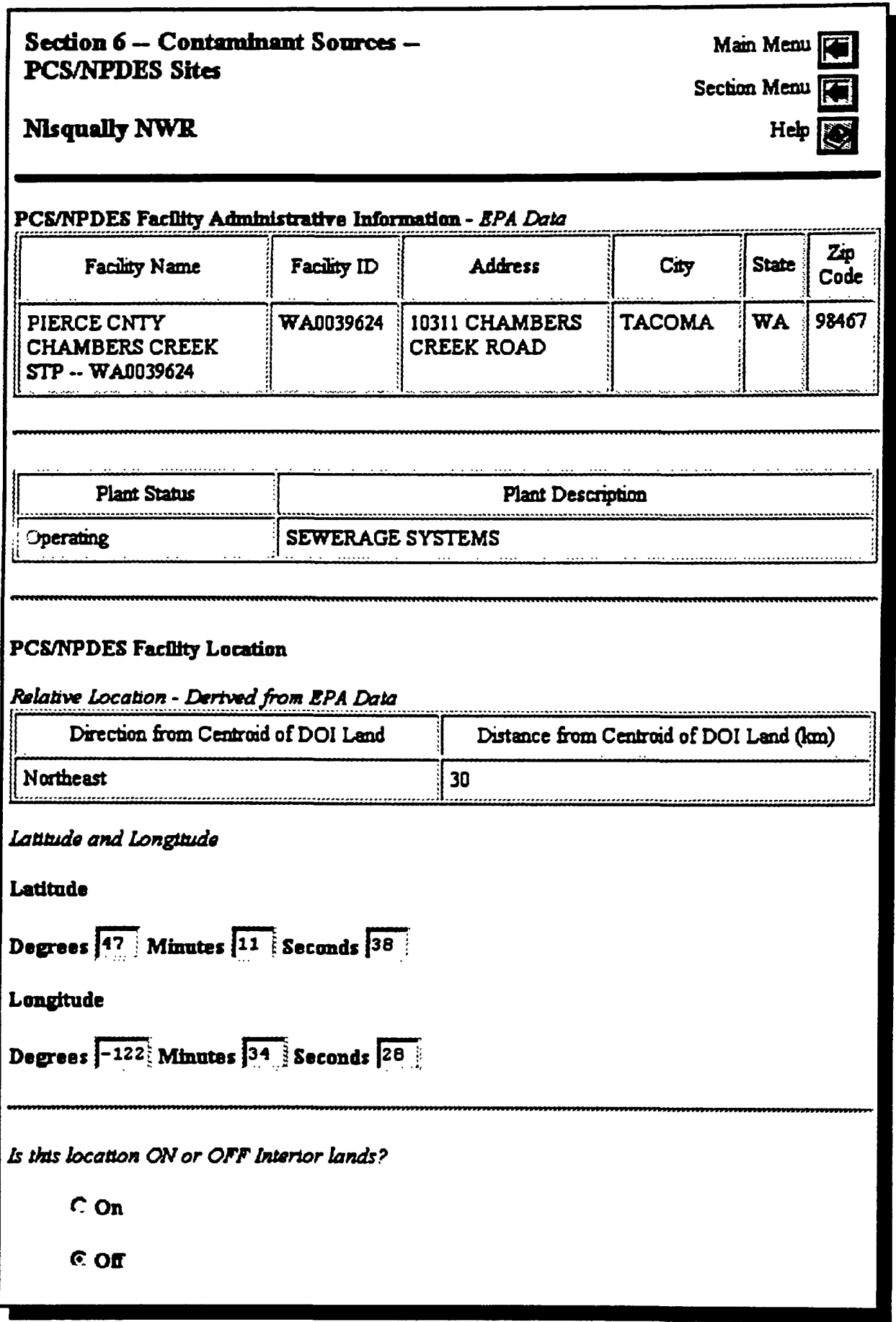

Figure 6-2. Data entry screen: Contaminant Source Information PCS/NPDES Sites. 
Table 6-2. Concluded.

\begin{tabular}{|c|c|c|}
\hline Field Name & Content Guidance/Erample & Data Entry Tips \\
\hline \multicolumn{3}{|c|}{ NPDES Reported Discharges and Permit Levels - EPA Data } \\
\hline Receiving Water & $\begin{array}{l}\text { This field contains the name of each receiving stream or water body } \\
\text { into which the chemicals are directly discharged, as it appears on } \\
\text { the NPDES facility permit. Erample: No date. }\end{array}$ & $\begin{array}{l}\text { Database query results. } \\
\text { Read only. }\end{array}$ \\
\hline Pipe ID & $\begin{array}{l}\text { This field contains the number of the pipe as it appears on the } \\
\text { NPDES facility permit. Example: 001. }\end{array}$ & $\begin{array}{l}\text { Database query results. } \\
\text { Read only. }\end{array}$ \\
\hline $\begin{array}{l}\text { Permitted } \\
\text { Parameters } \\
\end{array}$ & $\begin{array}{l}\text { This field contains the permitted parameter as it appears on the } \\
\text { NPDES facility permit. Erample: BOD, 5-DAY (20 DEG. C). }\end{array}$ & $\begin{array}{l}\text { Database query results. } \\
\text { Read only. }\end{array}$ \\
\hline \multicolumn{3}{|c|}{ Permitted Limit } \\
\hline $\begin{array}{l}\text { Average } \\
\text { Discharge }\end{array}$ & $\begin{array}{l}\text { This field contains the monthly average amount (lbs) of chemicals } \\
\text { permitted to be released from the plant. "No data" indicates release } \\
\text { information was not reported. Erample: } 3000 \text { LBS/DAY. } \\
\end{array}$ & $\begin{array}{l}\text { Database query results. } \\
\text { Read only. }\end{array}$ \\
\hline $\begin{array}{l}\text { Maximum } \\
\text { Discharge }\end{array}$ & $\begin{array}{l}\text { This field contains the daily maximum amount (lbs) of chemicals } \\
\text { permitted to be released from the plant. "No data" indicates release } \\
\text { information was not reported. Example: } 4500 \text { LBS/DAY. }\end{array}$ & $\begin{array}{l}\text { Database query results. } \\
\text { Read only. }\end{array}$ \\
\hline $\begin{array}{l}\text { Category(s) } \\
\text { where this } \\
\text { contaminant } \\
\text { SOURCE best } \\
\text { fits? }\end{array}$ & $\begin{array}{l}\text { Use this picklist to categorize the types of contaminant sources } \\
\text { (point and nonpoint) that are described in the reference. If the } \\
\text { reference does not describe a contaminant source, do not make a } \\
\text { selection from the picklist. Example: Municipal Wastewater. }\end{array}$ & $\begin{array}{l}\text { Picklist: up to } 70 \\
\text { selections. Defaults to } \\
\text { "Not Applicable." }\end{array}$ \\
\hline $\begin{array}{l}\text { Contaminant } \\
\text { classifications } \\
\text { linked to this } \\
\text { source }\end{array}$ & $\begin{array}{l}\text { Use this picklist to classify the contaminant categories that are } \\
\text { described in the reference. If the reference does not describe a } \\
\text { contaminant category, do not make a selection from the picklist. } \\
\text { Example: Water BOD, Sewage, Suspended Solids, Total Solids. }\end{array}$ & $\begin{array}{l}\text { Picklist: Up to } 64 \\
\text { selections. Defaults to } \\
\text { "Not Applicable." }\end{array}$ \\
\hline \multicolumn{3}{|c|}{ Pathways That Allow Contaminant(s) to Reach the Trust Area } \\
\hline Surface Water & Erample: PUGET SOUND \& CHAMBERS CREEK & Character limit: 2,000 \\
\hline Ground Water & $\begin{array}{l}\text { Pathways described in Section } 5 \text { are presented in this record as a } \\
\text { picklist. Select the pathway(s) by which contaminants released from } \\
\text { the facility are conducted to the refuge. Example: None selected. }\end{array}$ & $\begin{array}{l}\text { Picklist: Multiple } \\
\text { pathways can be } \\
\text { selected. }\end{array}$ \\
\hline Air & $\begin{array}{l}\text { Eight cardinal directions presented in a picklist. Select the wind } \\
\text { direction by which contaminants released from the facility may } \\
\text { reach refuge. Example: Northeast. }\end{array}$ & $\begin{array}{l}\text { Picklist: Multiple } \\
\text { pathways can be } \\
\text { selected. }\end{array}$ \\
\hline Biotic & $\begin{array}{l}\text { Potential biological contaminant vectors from Section 5: Pathways, } \\
\text { are listed here. Select those organisms that may transport } \\
\text { contaminants from the site to the refuge. Erample: None. }\end{array}$ & $\begin{array}{l}\text { Picklist: Multiple } \\
\text { pathways can be } \\
\text { selected. }\end{array}$ \\
\hline Comments & $\begin{array}{l}\text { Describe characteristics about this facility that may have particular } \\
\text { relevance to the contaminant assessment. Enter any ancillary } \\
\text { information that is not covered adequately by the picklist of } \\
\text { contaminants. Comments may include water or air quality } \\
\text { parameters that are likely to be impacted by the operation of the } \\
\text { facility. Example: None provided. }\end{array}$ & Character limit: 2,000 \\
\hline $\begin{array}{l}\text { Contacts linked } \\
\text { to this site }\end{array}$ & $\begin{array}{l}\text { Provides a picklist of contacts previously entered. Select name of } \\
\text { individual with knowledge about the source. If name is not } \\
\text { presented in the picklist, enter it in the fields below. Submit picklist } \\
\text { names and new names concurrently. Example: None highlighted. }\end{array}$ & $\begin{array}{l}\text { Picklist: Defaults to "No } \\
\text { Contact." }\end{array}$ \\
\hline \multirow[t]{2}{*}{ Add new contact } & Surname and title of contact. Example: None added. & Character limit: 40 \\
\hline & Last name of contact. Example: None added. & Character limit: 40 \\
\hline
\end{tabular}




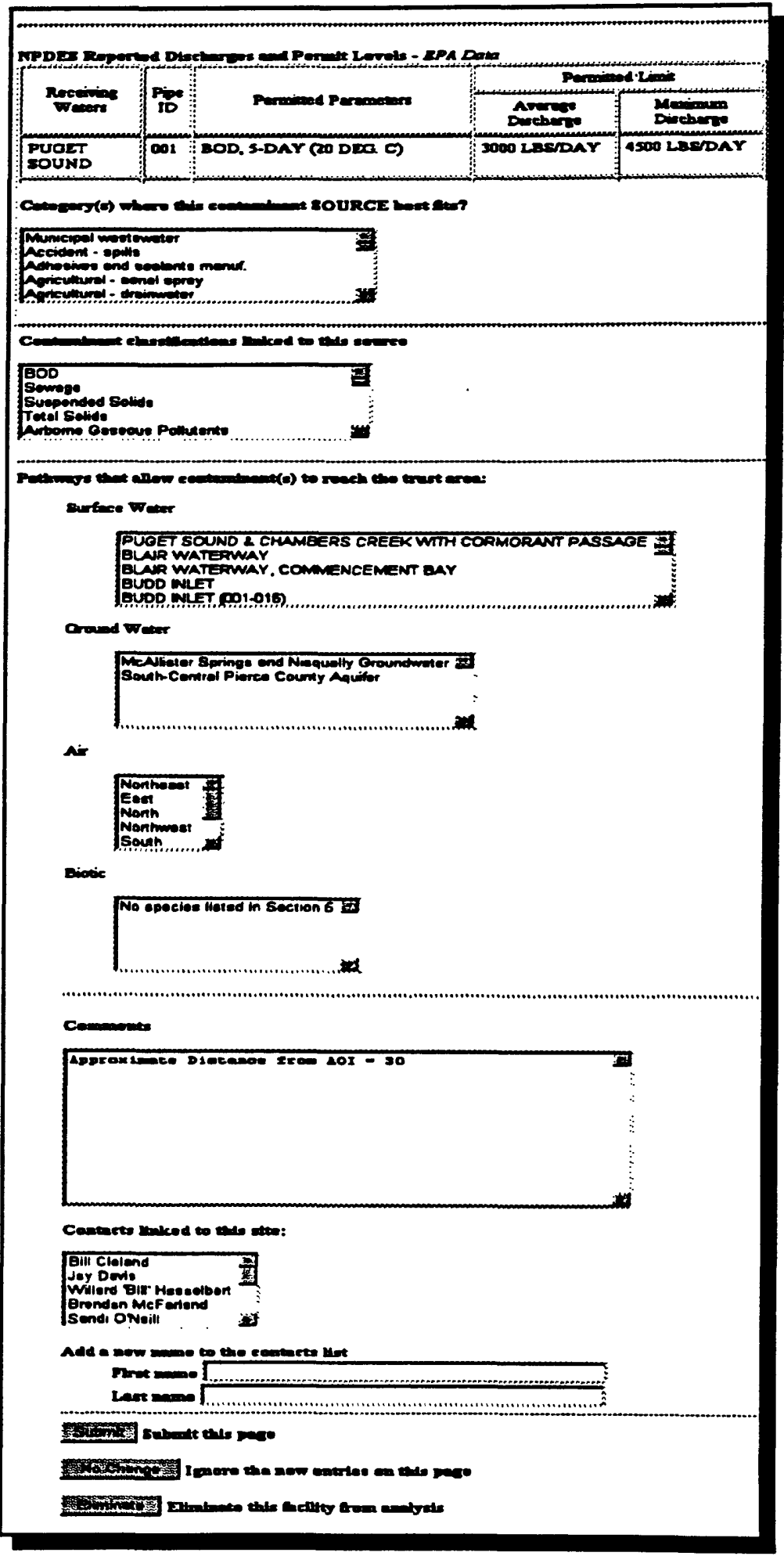

Figure 6-2. Concluded. 
Table 6-3. Field descriptions and examples: Contaminant Source Information - CERCLIS Sites.

\begin{tabular}{l|l|l}
\hline \multicolumn{1}{c|}{ Field Name } & \multicolumn{1}{|c}{ Content Guidance/Erample } & \multicolumn{1}{|c}{ Data Entry Tips } \\
\hline Site Name & $\begin{array}{l}\text { Name of facility and database specific identification number. } \\
\text { Erample: AMERICAN LAKE GARDENS/MCCHORD } \\
\text { AFB - WAD980833065. }\end{array}$ & $\begin{array}{l}\text { Database query results. } \\
\text { Read only. }\end{array}$ \\
\hline Site ID & $\begin{array}{l}\text { This field contains the unique identification assigned by the } \\
\text { database. Example: WAD980833065. }\end{array}$ & $\begin{array}{l}\text { Database query results. } \\
\text { Read only. }\end{array}$ \\
\hline Address & $\begin{array}{l}\text { This field contains the first line of the street name in the address of } \\
\text { the facility. Example: 6411 146TH ST SW. }\end{array}$ & $\begin{array}{l}\text { Database query results. } \\
\text { Read only. }\end{array}$ \\
\hline City & $\begin{array}{l}\text { This field contains the city in which the facility is located. } \\
\text { Example: TACOMA. }\end{array}$ & $\begin{array}{l}\text { Database query results. } \\
\text { Read only. }\end{array}$ \\
\hline State & $\begin{array}{l}\text { This field contains the state in which the facility is located. } \\
\text { Example: WA. }\end{array}$ & $\begin{array}{l}\text { Database query results. } \\
\text { Read only. }\end{array}$ \\
\hline Zip Code & $\begin{array}{l}\text { This field contains the zip code in which the facility is located. } \\
\text { Example: 98439. }\end{array}$ & $\begin{array}{l}\text { Database query results. } \\
\text { Read only. }\end{array}$ \\
\hline NPL Status & $\begin{array}{l}\text { This field indicates whether or not the site is currently listed on the } \\
\text { National Priority List (NPL) Example: Currently on the final } \\
\text { NPL. }\end{array}$ & $\begin{array}{l}\text { Database query results. } \\
\text { Read only. }\end{array}$ \\
\hline
\end{tabular}

CERCLIS Location, Relative Location - Derived from EPA Data

\begin{tabular}{|c|c|c|}
\hline $\begin{array}{l}\text { Direction from } \\
\text { Centroid of DOI } \\
\text { Land }\end{array}$ & $\begin{array}{l}\text { This field contains the direction of the facility relative to the refuge. } \\
\text { It is calculated by the data management system. Erample: East. }\end{array}$ & $\begin{array}{l}\text { Calculated direction. } \\
\text { Read only. }\end{array}$ \\
\hline $\begin{array}{l}\text { Distance from } \\
\text { Centroid of DOI } \\
\text { Land (km) }\end{array}$ & $\begin{array}{l}\text { This field contains the distance }(\mathrm{km}) \text { of the facility to the refuge. It } \\
\text { is calculated by the data management system. Example: } 30 \text {. }\end{array}$ & $\begin{array}{l}\text { Calculated distance. } \\
\text { Read only. }\end{array}$ \\
\hline \multicolumn{3}{|c|}{ CERCLIS Location - Latitude } \\
\hline Degrees & $\begin{array}{l}\text { Distance of the facility north or south of the equator, measured on a } \\
\text { meridian, expressed in degrees. Example: } 47 \text {. }\end{array}$ & $\begin{array}{l}\text { Character limit: } 2 \\
\text { Database query results. } \\
\text { Can be user-edited. }\end{array}$ \\
\hline Minutes & $\begin{array}{l}\text { Distance of the facility north or south of the equator, measured on a } \\
\text { meridian, expressed in minutes Example 7. }\end{array}$ & $\begin{array}{l}\text { Character limit: } 2 \\
\text { Database query results. } \\
\text { Can be user-edited. }\end{array}$ \\
\hline Seconds & $\begin{array}{l}\text { Distance of the facility north or south of the equator, measured on a } \\
\text { meridian, expressed in seconds. Example } 30 \text {. }\end{array}$ & $\begin{array}{l}\text { Character limit: } 2 \\
\text { Database query results. } \\
\text { Can be user-edited. }\end{array}$ \\
\hline \multicolumn{3}{|c|}{ CERCLIS Location - Longitude } \\
\hline Degrees & $\begin{array}{l}\text { The location of the facility in reference to the prime meridian } \\
\text { expressed in degrees. Example: }-\mathbf{1 2 2} \text {. }\end{array}$ & $\begin{array}{l}\text { Character limit: } 3 \\
\text { ("“" in N. America). } \\
\text { Can be user-edited. }\end{array}$ \\
\hline Minutes & $\begin{array}{l}\text { The location of the facility in reference to the prime meridian } \\
\text { expressed in minutes. Example: } 31 \text {. }\end{array}$ & $\begin{array}{l}\text { Character limit: } 2 \\
\text { Database query results. } \\
\text { Can be user-edited. }\end{array}$ \\
\hline Seconds & $\begin{array}{l}\text { The location of the facility in reference to the prime meridian } \\
\text { expressed in seconds. Erample: } 20 \text {. }\end{array}$ & $\begin{array}{l}\text { Database query results. } \\
\text { Can be user-edited. } \\
\text { Character limit: } 2 \\
\end{array}$ \\
\hline $\begin{array}{l}\text { Is this location } \\
\text { ON or OFF } \\
\text { Interior lands? }\end{array}$ & $\begin{array}{l}\text { Classify facility as being located within the refuge boundary or } \\
\text { outside of the boundary. Example: Off. }\end{array}$ & $\begin{array}{l}\text { Radio button. One } \\
\text { selection allowed. }\end{array}$ \\
\hline
\end{tabular}




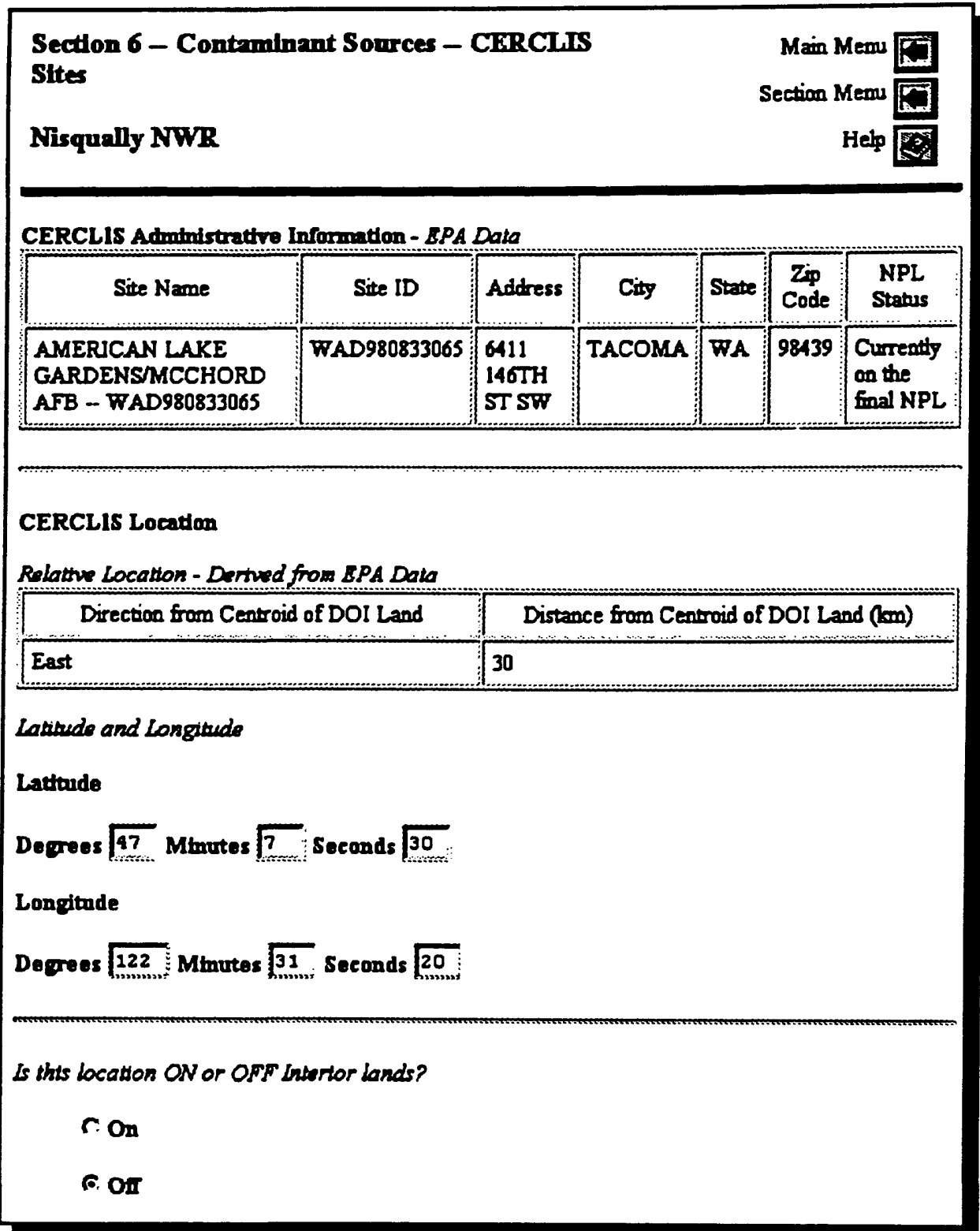

Figure 6-3. Data entry screen: Contaminant Source Information CERCLIS Sites. 
Table 6-3. Concluded.

\begin{tabular}{|c|c|c|}
\hline Field Name & Content Guidance/Erample & Data Entry Tips \\
\hline \multicolumn{3}{|c|}{ Site Reports - EPA Data } \\
\hline $\begin{array}{l}\text { Record of } \\
\text { Decision (ROD) }\end{array}$ & $\begin{array}{l}\text { Selecting link displays the ROD for the site from the CERCLIS } \\
\text { database. Review text and summarize pertinent information in } \\
\text { Contaminant Source, Classification Comments fields. Example: } \\
\text { Available. }\end{array}$ & $\begin{array}{l}\text { Hypertext link. If } \\
\text { “Available," selecting } \\
\text { link displays ROD. }\end{array}$ \\
\hline EPA Fact Sheet & $\begin{array}{l}\text { Selecting link displays the Fact Sheet for the site from the } \\
\text { CERCLIS database. Review text and summarize pertinent } \\
\text { information in Contaminant Source, Classification Comments } \\
\text { fields. Example: Available. }\end{array}$ & $\begin{array}{l}\text { Hypertext link. If } \\
\text { “Available," selecting } \\
\text { link displays Fact Sheet. }\end{array}$ \\
\hline $\begin{array}{l}\text { Category(s) this } \\
\text { contaminant } \\
\text { SOURCE best } \\
\text { fits? }\end{array}$ & $\begin{array}{l}\text { Use this picklist to document the types of contaminant sources } \\
\text { (point and nonpoint) that are described in the reference. If the } \\
\text { reference does not describe a contaminant source, do not make a } \\
\text { selection from the picklist. Example: None selected. }\end{array}$ & $\begin{array}{l}\text { Picklist. Up to } 70 \\
\text { selections. Defaults to } \\
\text { "Not Applicable." }\end{array}$ \\
\hline $\begin{array}{l}\text { Contaminant } \\
\text { classifications } \\
\text { linked to this } \\
\text { source }\end{array}$ & $\begin{array}{l}\text { Use this picklist to document the contaminant categories that are } \\
\text { described in the reference. If the reference does not describe a } \\
\text { contaminant category, do not make a selection from the picklist. } \\
\text { Example: None selected. }\end{array}$ & $\begin{array}{l}\text { Picklist. Up to } 64 \\
\text { selections. Defaults to } \\
\text { "Not Applicable." }\end{array}$ \\
\hline \multicolumn{3}{|c|}{ Pathways That Allow Contaminant(s) to Reach the Trust Area } \\
\hline Surface Water & $\begin{array}{l}\text { Pathways described in Section 5: Pathways, are presented in this } \\
\text { record as a picklist. Select the pathway(s) by which contaminants } \\
\text { released from the facility are conducted to the refuge. Erample: } \\
\text { CHAMBERS CREEK \& BAY. }\end{array}$ & Character limit: 2,000 \\
\hline Ground Water & $\begin{array}{l}\text { Pathways described in Section 5: Pathways, are presented in this } \\
\text { record as a picklist. Select the pathway(s) by which contaminants } \\
\text { released from the facility are conducted to the refuge. Erample: } \\
\text { South Central Pierce County Aquifer. }\end{array}$ & $\begin{array}{l}\text { Picklist. Multiple } \\
\text { pathways can be } \\
\text { selected. }\end{array}$ \\
\hline Air & $\begin{array}{l}\text { Eight cardinal directions presented in a picklist. Select the wind } \\
\text { direction by which contaminants released from the facility may } \\
\text { reach refuge. Example: East. }\end{array}$ & $\begin{array}{l}\text { Picklist. Multiple } \\
\text { pathways can be } \\
\text { selected. }\end{array}$ \\
\hline Biotic & $\begin{array}{l}\text { Potential biological contaminant vectors from Section 5: Pathways, } \\
\text { are listed here. Select organisms that may transport contaminants } \\
\text { from the site to the refuge. Example: No species listed in Sec. } 5 \text {. }\end{array}$ & $\begin{array}{l}\text { Picklist. Multiple species } \\
\text { can be selected. Defaults } \\
\text { to "No Selection." }\end{array}$ \\
\hline Comments & $\begin{array}{l}\text { Describe characteristics about this facility that may have particular } \\
\text { relevance to the contaminant assessment. Enter any ancillary } \\
\text { information that is not covered adequately by the picklist of } \\
\text { contaminants. Comments may include water or air quality } \\
\text { parameters that are likely to be impacted by the operation of the } \\
\text { facility. Erample: Currently on the final NPL ADMIN/ } \\
\text { VOLUNTARY COST RECOVERY - 15-DEC-95 FEDERAL } \\
\text { INTERAGENCY AGREEMENT..... See EPA's NPL Fact Sheet } \\
\text { and Superfund Site Report for details concerning contaminant } \\
\text { source and classification. }\end{array}$ & Character limit: 2,000 \\
\hline $\begin{array}{l}\text { Contacts linked } \\
\text { to this site }\end{array}$ & $\begin{array}{l}\text { Provides a picklist of contacts previously entered. Select name of } \\
\text { individual with knowledge about the source. Enter new names in } \\
\text { the fields below. Erample: Bill Cleland. }\end{array}$ & $\begin{array}{l}\text { Picklist. Defaults to "No } \\
\text { Contact." }\end{array}$ \\
\hline \multirow[t]{2}{*}{ Add new contact } & Surname and title of contact. Example: None added. & Character limit: 40 \\
\hline & Last name of contact. Example: None added. & Character limit: 40 \\
\hline
\end{tabular}




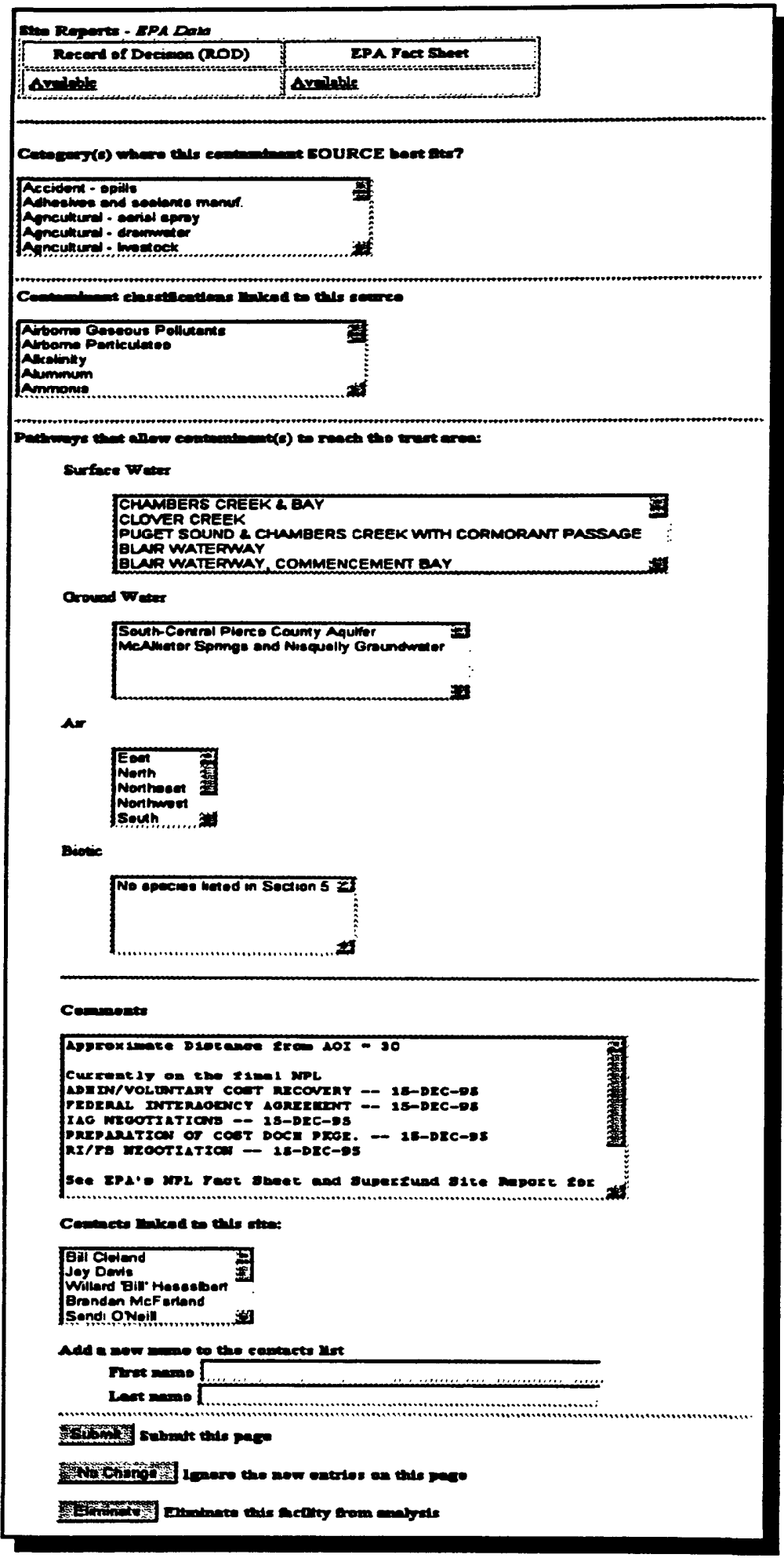

Figure 6-3. Concluded. 
Table 6-4. Field descriptions and examples: Contaminant Source Information - AIRS Sites.

\begin{tabular}{|c|c|c|}
\hline Field Name & Content Guidance/Eramples & Data Entry Tips \\
\hline Facility Name & $\begin{array}{l}\text { Name of facility and database specific identification number. } \\
\text { Example: FARMLAND INDUSTRIES INC.-REFINERY DIV. } \\
\text { KS0057077. }\end{array}$ & $\begin{array}{l}\text { Database query results. } \\
\text { Read only. }\end{array}$ \\
\hline Facility ID & $\begin{array}{l}\text { This field contains the unique identification assigned by the } \\
\text { database. Example: KS0057077. }\end{array}$ & $\begin{array}{l}\text { Database query results. } \\
\text { Read only. } \\
\end{array}$ \\
\hline Address & $\begin{array}{l}\text { This field contains the first line of the street name in the address of } \\
\text { the facility. Example: NORTH HWY 183. }\end{array}$ & $\begin{array}{l}\text { Database query results. } \\
\text { Read only. }\end{array}$ \\
\hline City & $\begin{array}{l}\text { This field contains the city in which the facility is located. } \\
\text { Example: PEIILLIPSBURG. }\end{array}$ & $\begin{array}{l}\text { Database query results. } \\
\text { Read only. }\end{array}$ \\
\hline State & $\begin{array}{l}\text { This field contains the state in which the facility is located. } \\
\text { Example: KS. }\end{array}$ & $\begin{array}{l}\text { Database query results. } \\
\text { Read only. }\end{array}$ \\
\hline Zip Code & $\begin{array}{l}\text { This field contains the zip code in which the facility is located. } \\
\text { Erample: } 67661 \text {. }\end{array}$ & $\begin{array}{l}\text { Database query results. } \\
\text { Read only. }\end{array}$ \\
\hline Plant Status & $\begin{array}{l}\text { This field contains the operating status of the facility. Example: } \\
\text { Operating. }\end{array}$ & $\begin{array}{l}\text { Database query results. } \\
\text { Read only. }\end{array}$ \\
\hline $\begin{array}{l}\text { Plant } \\
\text { Description }\end{array}$ & $\begin{array}{l}\text { This field contains the description for the SIC code, describing type } \\
\text { of activities at the facility. Erample: PETROLEUM REFINING. }\end{array}$ & $\begin{array}{l}\text { Database query results. } \\
\text { Read only. }\end{array}$ \\
\hline \multicolumn{3}{|c|}{ AIRS Facility Relative Location - Derived from EPA Data } \\
\hline $\begin{array}{l}\text { Direction from } \\
\text { Centroid of DOI } \\
\text { Land }\end{array}$ & $\begin{array}{l}\text { This field contains the direction of the facility relative to the refuge. } \\
\text { It is calculated by the data management system. Erample: } \\
\text { Northwest. }\end{array}$ & $\begin{array}{l}\text { Calculated direction. } \\
\text { Read only. }\end{array}$ \\
\hline $\begin{array}{l}\text { Distance from } \\
\text { Centroid of DOI } \\
\text { Land (km) }\end{array}$ & $\begin{array}{l}\text { This field contains the distance }(\mathbf{k m}) \text { of the facility to the refuge. It } \\
\text { is calculated by the data management system. Example: } \mathbf{3 0} \text {. }\end{array}$ & $\begin{array}{l}\text { Calculated distance. } \\
\text { Read only. }\end{array}$ \\
\hline \multicolumn{3}{|c|}{ AIRS Facility Location - Latitude } \\
\hline Degrees & $\begin{array}{l}\text { Distance of the facility north or south of the equator, measured on a } \\
\text { meridian, expressed in degrees. Example: } 39 \text {. }\end{array}$ & $\begin{array}{l}\text { Character limit: } 2 \\
\text { Database query results. } \\
\text { Can be user-edited. } \\
\end{array}$ \\
\hline Minutes & $\begin{array}{l}\text { Distance of the facility north or south of the equator, measured on a } \\
\text { meridian, expressed in minutes. Erample: } 47 \text {. }\end{array}$ & \begin{tabular}{|l|} 
Character limit: 2. \\
Database query results. \\
Can be user-edited. \\
\end{tabular} \\
\hline Seconds & $\begin{array}{l}\text { Distance of the facility north or south of the equator, measured on a } \\
\text { meridian, expressed in seconds. Example: } 14 \text {. }\end{array}$ & $\begin{array}{l}\text { Character limit: } 2 . \\
\text { Database query results. } \\
\text { Can be user-edited. }\end{array}$ \\
\hline \multicolumn{3}{|c|}{ AIRS Facility Location - Longitude } \\
\hline Degrees & $\begin{array}{l}\text { The location of the facility in reference to the prime meridian, } \\
\text { expressed in degrees. Erample: }-122 \text {. }\end{array}$ & $\begin{array}{l}\text { Character limit: } 3 . \\
\text { ("_" in N. America) } \\
\text { Database query results. } \\
\text { Can be user-edited. } \\
\end{array}$ \\
\hline Minutes & $\begin{array}{l}\text { The location of the facility in reference to the prime meridian, } \\
\text { expressed in minutes. Example: } 46 \text {. }\end{array}$ & $\begin{array}{l}\text { Character limit: } 2 \text {. } \\
\text { Database query results. } \\
\text { Can be user-edited. } \\
\end{array}$ \\
\hline Seconds & $\begin{array}{l}\text { The location of the facility in reference to the prime meridian, } \\
\text { expressed in seconds. Example: } 35 \text {. }\end{array}$ & $\begin{array}{l}\text { Character limit: } 2 . \\
\text { Database query results. } \\
\text { Can be user-edited. } \\
\end{array}$ \\
\hline $\begin{array}{l}\text { Is this location } \\
\text { ON or OFF } \\
\text { Interior lands? }\end{array}$ & $\begin{array}{l}\text { Classify facility as being located within the refuge boundary or } \\
\text { outside of the boundary. Erample: Off. }\end{array}$ & $\begin{array}{l}\text { Radio button. One } \\
\text { selection allowed. }\end{array}$ \\
\hline
\end{tabular}


Section 6 - Contaminant Sources - AIRS Sttes

Main Mem 7

Kirwin NWR

AIRS Facility Administrative Information - BPA Data

\begin{tabular}{|l|c|c|c|c|c|}
\hline \multicolumn{1}{|c|}{ Facility Name } & Facility ID & Address & City & State & Cod \\
\hline $\begin{array}{l}\text { FARMLAND INDUSTRIES } \\
\text { INC.REFINERY DIV. .- } \\
\text { KSO0ST07 }\end{array}$ & KSO05707 & NORTH & PHILLIPSBURG & KS & O7661 \\
\hline
\end{tabular}

\begin{tabular}{|c|c|}
\hline Plant Status & Plant Description \\
\hline Operating & PETROLEUM REFINING \\
\hline
\end{tabular}

AJRS Faclity Location

Relatue Location - Dortued from EPA Date

Direction from Cemtroid of DOl Land Distance from Centroid of DOI Land (km)

Northwest 30

Laturede and Longtuede

Latitude

Degrees $\sqrt{39}$ Minutes $\sqrt{47}$ Seconds $\sqrt{14}$

Lonottude

Degrees 9 Minutes 22 Seconds 17

Is this bocation ON or OFF' Interior lands?

r. on

คr or

Figure 6-4. Data entry screen: Contaminant Source Information - AIRS Sites. 
Table 6-4. Concluded.

\begin{tabular}{|c|c|c|}
\hline Field Name & Content Guidance/Examples & Data Entry Tips \\
\hline \multicolumn{3}{|c|}{ Reported AIR Releases for Major Discharges - EPA Data } \\
\hline $\begin{array}{l}\text { Discharged } \\
\text { Chemicals }\end{array}$ & Chemicals reported released at facility. Example: No data. & $\begin{array}{l}\text { Database query results. } \\
\text { Read only. }\end{array}$ \\
\hline $\begin{array}{l}\text { Category(s) } \\
\text { where this } \\
\text { contaminant } \\
\text { SOURCE best } \\
\text { fits? }\end{array}$ & $\begin{array}{l}\text { Use this picklist to document the types of contaminant sources } \\
\text { (point and nonpoint) that are described in the reference. If the } \\
\text { reference does not describe a contaminant source, do not make a } \\
\text { selection from the picklist. Example: Petroleum Refining, } \\
\text { Accidents- Spills, Contaminated sediments/soils, Petroleum } \\
\text { evaporation/production. }\end{array}$ & $\begin{array}{l}\text { Picklist. Up to } 70 \\
\text { selections. Defaults to } \\
\text { "Not Applicable." }\end{array}$ \\
\hline $\begin{array}{l}\text { Contaminant } \\
\text { classifications } \\
\text { linked to this } \\
\text { source }\end{array}$ & $\begin{array}{l}\text { Use this picklist to document the contaminant categories that are } \\
\text { described in the reference. If the reference does not describe a } \\
\text { contaminant category, do not make a selection from the picklist. } \\
\text { Erample: Airborne Gaseous Products, Airborne Particulates, } \\
\text { Oil and Grease, Petroleum Products, Polyaromatic } \\
\text { Hydrocarbons. }\end{array}$ & $\begin{array}{l}\text { Picklist. Up to } 64 \\
\text { selections. Defaults to } \\
\text { "Not Applicable." }\end{array}$ \\
\hline \multicolumn{3}{|c|}{ Pathways That Allow Contaminant(s) to Reach the Trust Area } \\
\hline Surface Water & $\begin{array}{l}\text { Pathways described in Section } 5 \text { are presented in this record as a } \\
\text { picklist. Select the pathway(s) by which contaminants released from } \\
\text { the facility are conducted to the refuge. Erample: None selected. }\end{array}$ & Character limit: 2,000 \\
\hline Ground Water & $\begin{array}{l}\text { Pathways described in Section } 5 \text { are presented in this record as a } \\
\text { picklist. Select the pathway(s) by which contaminants released from } \\
\text { the facility are conducted to the refuge. Example: Dakota Aquifer, } \\
\text { High Plains Aquifer, Kiowa Shale Aquitard. }\end{array}$ & $\begin{array}{l}\text { Picklist. Multiple } \\
\text { pathways can be } \\
\text { selected. }\end{array}$ \\
\hline Air & $\begin{array}{l}\text { Eight cardinal directions presented in a picklist. Select the wind } \\
\text { direction by which contaminants released from the facility may } \\
\text { reach refuge. Erample: East Northwest selected. }\end{array}$ & $\begin{array}{l}\begin{array}{l}\text { Picklist. Multiple } \\
\text { pathways can be } \\
\text { selected. }\end{array} \\
\end{array}$ \\
\hline Biotic & $\begin{array}{l}\text { Potential biological contaminant vectors from Section 5: Pathways, } \\
\text { are listed here. Select those organisms that may transport } \\
\text { contaminants from the site to the refuge. Example: None selected. }\end{array}$ & $\begin{array}{l}\text { Picklist. Multiple species } \\
\text { can be selected. } \\
\text { Defaults to "No } \\
\text { Selection." }\end{array}$ \\
\hline Comments & $\begin{array}{l}\text { Describe characteristics about this facility that may have particular } \\
\text { relevance to the contaminant assessment. Enter any ancillary } \\
\text { information that is not covered adequately by the picklist of } \\
\text { contaminants. Comments may include water or air quality } \\
\text { parameters that are likely to be impacted by the operation of the } \\
\text { facility. Example: Approximate Distance from AOI = 30 km. } \\
\text { Releases include Carbon Monoxide, Cobalt, Nitrogen Dioxide, } \\
\text { Sulfur Dioxide, Particulate Matter, and Volatile Organic } \\
\text { Compounds. Cobalt is highly toxic. Releases from this site would } \\
\text { cause the most concern during the winter months when the } \\
\text { winds are predominately from the north. Due to the distance } \\
\text { from the facility to the Refuge and the relatively small size of } \\
\text { the facility, I do not believe that releases from this facility } \\
\text { generally pose a problem to the Refuge. }\end{array}$ & Character limit: 2,000 \\
\hline $\begin{array}{l}\text { Contacts linked } \\
\text { to this site }\end{array}$ & Example: Terry Pedinger. & $\begin{array}{l}\text { Picklist. Default is "No } \\
\text { Contact." }\end{array}$ \\
\hline \multirow[t]{2}{*}{ Add new contact } & Surname and title of contact. Example: None added. & Character limit: 40 \\
\hline & Last name of contact. Example: None added. & Character limit: 40 \\
\hline
\end{tabular}




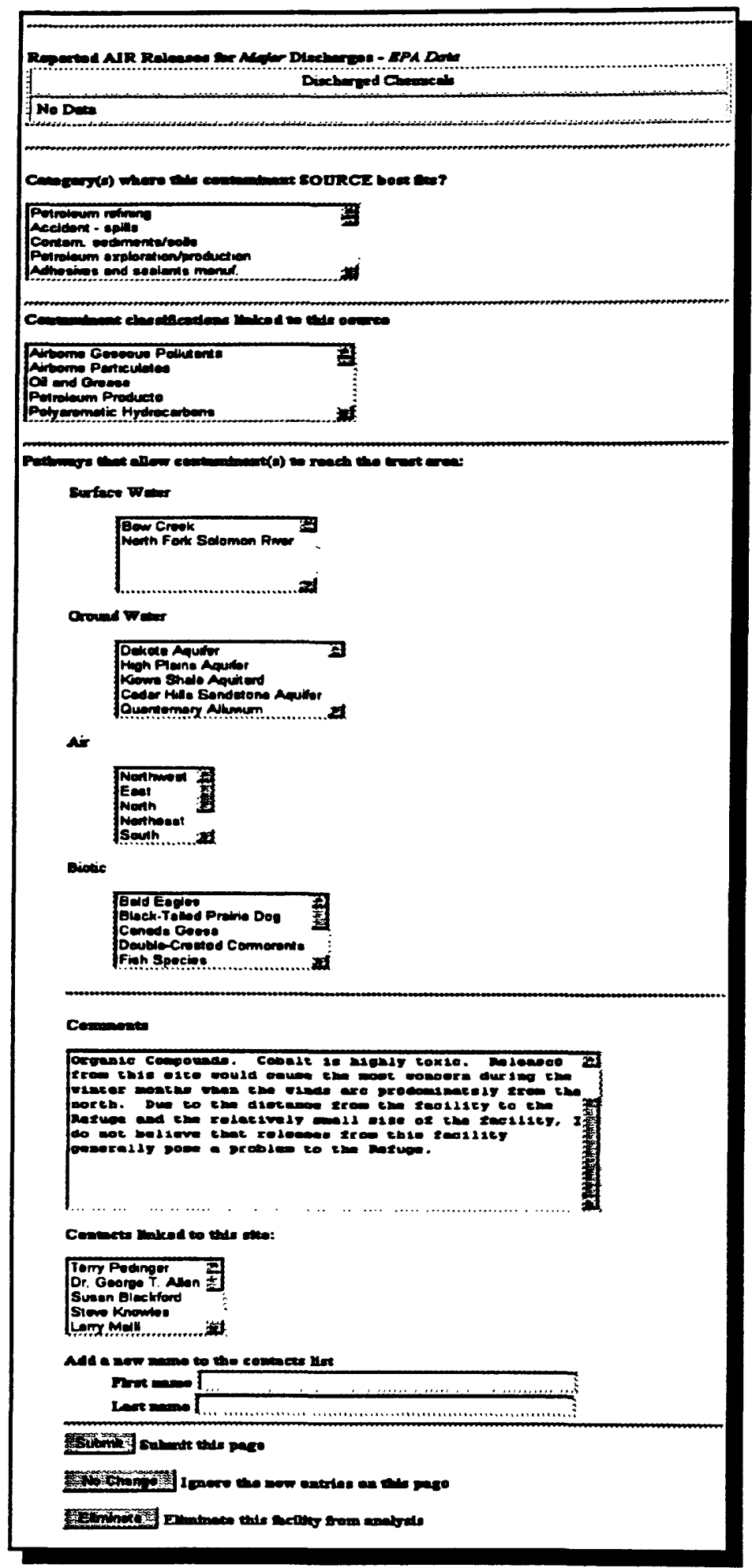

Figure 6.4. Concluded. 
Table 6-5. Field descriptions and examples: Contaminant Source Information - RCRIS Sites.

\begin{tabular}{|c|c|c|}
\hline Field Name & Content Guidance/Example & Data Entry Tips \\
\hline Facility Name & $\begin{array}{l}\text { Name of facility and database specific identification number.- } \\
\text { Example: FARMIAND INDUSTRIES INC - KSD007134695. }\end{array}$ & $\begin{array}{l}\text { Database query results. } \\
\text { Read only. }\end{array}$ \\
\hline Facility ID & $\begin{array}{l}\text { This field contains the unique identification assigned by the } \\
\text { database. Example: KSD007134695. }\end{array}$ & $\begin{array}{l}\text { Database query results. } \\
\text { Read only. }\end{array}$ \\
\hline Address & $\begin{array}{l}\text { This field contains the first line of the street name in the address of } \\
\text { the facility. Example: HWY 183, } 25 \text { MI N OF TOWN. }\end{array}$ & $\begin{array}{l}\text { Database query results. } \\
\text { Read only. }\end{array}$ \\
\hline City & $\begin{array}{l}\text { This field contains the city in which the facility is located. } \\
\text { Example: PHILLIPSBUR. }\end{array}$ & $\begin{array}{l}\text { Database query results. } \\
\text { Read only. }\end{array}$ \\
\hline State & $\begin{array}{l}\text { This field contains the state in which the facility is located. } \\
\text { Example: KS. }\end{array}$ & $\begin{array}{l}\text { Database query results. } \\
\text { Read only. }\end{array}$ \\
\hline Zip Code & $\begin{array}{l}\text { This field contains the zip code in which the facility is located. } \\
\text { Example: } 67661 \text {. }\end{array}$ & $\begin{array}{l}\text { Database query results. } \\
\text { Read only. }\end{array}$ \\
\hline Plant Status & $\begin{array}{l}\text { This field contains the operating status of the facility. Example: } \\
\text { Large Quantity Generator Small Quantity Generator. }\end{array}$ & $\begin{array}{l}\text { Database query results. } \\
\text { Read only. }\end{array}$ \\
\hline $\begin{array}{l}\text { Plant } \\
\text { Description }\end{array}$ & $\begin{array}{l}\text { This field contains the description for the SIC code, describing type } \\
\text { of activities at the facility. Example: WHOLESALE TRADE - } \\
\text { PETROLEUM PRODUCTS, NEC. }\end{array}$ & $\begin{array}{l}\text { Database query results. } \\
\text { Read only. }\end{array}$ \\
\hline \multicolumn{3}{|c|}{ RCRIS Facility Relative Location - Derived from EPA Data } \\
\hline $\begin{array}{l}\text { Direction from } \\
\text { Centroid of DOI } \\
\text { Land }\end{array}$ & $\begin{array}{l}\text { This field contains the direction of the facility relative to the refuge. } \\
\text { It is calculated by the data management system. Example: } \\
\text { Northwest. }\end{array}$ & $\begin{array}{l}\text { Calculated direction. } \\
\text { Read only. }\end{array}$ \\
\hline $\begin{array}{l}\text { Distance from } \\
\text { Centroid of DOI } \\
\text { Land }(\mathrm{km})\end{array}$ & $\begin{array}{l}\text { This field contains the distance }(\mathrm{km}) \text { of the facility to the refuge. It } \\
\text { is calculated by the data management system. Example: } 30 \text {. }\end{array}$ & $\begin{array}{l}\text { Calculated distance. } \\
\text { Read only. }\end{array}$ \\
\hline \multicolumn{3}{|c|}{ RCRIS Facility Location - Latitude } \\
\hline Degrees & $\begin{array}{l}\text { Distance of the facility north or south of the equator, measured on a } \\
\text { meridian, expressed in degrees. Example: } 39 \text {. }\end{array}$ & \begin{tabular}{|l|} 
Character limit: 2 . \\
Database query results. \\
Can be user-edited. \\
\end{tabular} \\
\hline Minutes & $\begin{array}{l}\text { Distance of the facility north or south of the equator, measured on a } \\
\text { meridian, expressed in minutes. Example: } 46 \text {. }\end{array}$ & \begin{tabular}{|l|} 
Character limit: 2 . \\
Database query results. \\
Can be user-edited. \\
\end{tabular} \\
\hline Seconds & $\begin{array}{l}\text { Distance of the facility north or south of the equator, measured on a } \\
\text { meridian, expressed in seconds. Example: } 30 \text {. }\end{array}$ & $\begin{array}{l}\text { Character limit: } 2 . \\
\text { Database query results. } \\
\text { Can be user-edited. }\end{array}$ \\
\hline \multicolumn{3}{|c|}{ RCRIS Facility Location - Longitude } \\
\hline Degrees & $\begin{array}{l}\text { The location of the facility in reference to the prime meridian, } \\
\text { expressed in degrees. Example: }-99 \text {. }\end{array}$ & $\begin{array}{l}\text { Character limit: } 3 \text {. } \\
\text { ("“" in N. America) } \\
\text { Database query results. } \\
\text { Can be user-edited. }\end{array}$ \\
\hline Minutes & $\begin{array}{l}\text { The location of the facility in reference to the prime meridian, } \\
\text { expressed in minutes. Example: } 20 \text {. }\end{array}$ & \begin{tabular}{|l|} 
Character limit: 2. \\
Database query results. \\
Can be user-edited. \\
\end{tabular} \\
\hline Seconds & $\begin{array}{l}\text { The location of the facility in reference to the prime meridian, } \\
\text { expressed in seconds. Example: } 0 \text {. }\end{array}$ & \begin{tabular}{|l|} 
Character limit: 2. \\
Database query results. \\
Can be user-edited. \\
\end{tabular} \\
\hline $\begin{array}{l}\text { Is this location } \\
\text { ON or OFF } \\
\text { Interior lands? }\end{array}$ & $\begin{array}{l}\text { Classify facility as being located within the refuge boundary or } \\
\text { outside of the boundary. Example: Off. }\end{array}$ & $\begin{array}{l}\text { Radio Button. One } \\
\text { selection allowed. }\end{array}$ \\
\hline
\end{tabular}




\begin{tabular}{|c|c|c|c|c|c|}
\hline \multicolumn{3}{|c|}{$\begin{array}{l}\text { Section } 6 \text { - Contominant Sorrces - RCRIS } \\
\text { Sites }\end{array}$} & \multicolumn{3}{|c|}{ Main Mem } \\
\hline \multicolumn{3}{|l|}{ Krow NWR } & \multicolumn{2}{|r|}{ Help } & 8 \\
\hline \multicolumn{6}{|c|}{ RCRIS Faclity Administrattre Information - EPA Data } \\
\hline Faciling Name & Facility ID & Address & City & State & Code \\
\hline $\begin{array}{l}\text { FARMLAND } \\
\text { INDUSTRIES INC - } \\
\text { KSD007134695 }\end{array}$ & KSD007134695 & $\begin{array}{l}\text { HWY } 183, .25 \\
\text { MI N OF } \\
\text { TOWN }\end{array}$ & PHILLIPSBURG & KS & 07661 \\
\hline Plent Status & & Plant D & scription & & \\
\hline $\begin{array}{l}\text { Large Quantity Generator } \\
\text { Small Quentity Generator }\end{array}$ & WHOLESALE & TRADE - PETR & HEUM PRODUC & IS, NEC & \\
\hline
\end{tabular}

\section{RCRIS Faclity Location}

Relative Location - Dertwed from BPA Data

\begin{tabular}{|l|l|}
\hline Direction from Centroid of DOI Lend & Distance from Centroid of DOI Lend (kom) \\
\hline Northwest & 30 \\
\hline
\end{tabular}

Latreude and Longitude

Latitude

Degrees $\sqrt{39}$ Minutes $\sqrt{46}$ Seconds $\sqrt{30}$

Longitude

Degrees $\sqrt{99}$ Minutes $\sqrt{20}$ Seconds $\sqrt{0}$

Is this Location ON or OPf Interior lands?

con

cor

Figure 6-5. Data entry screen: Contaminant Source Information RCRIS Sites. 
Table 6-5. Concluded.

\begin{tabular}{|c|c|c|}
\hline Field Nane & Content Guidance/Erample & Data Entry Tips \\
\hline Waste Activity & $\begin{array}{l}\text { This field contains a description of the activity involving hazardous } \\
\text { materials reported at the facility Example: Handler is engaged in } \\
\text { generation of hazardous waste - Large Quantity Generator. }\end{array}$ & $\begin{array}{l}\text { Database query results. } \\
\text { Read only. }\end{array}$ \\
\hline $\begin{array}{l}\text { Category(s) } \\
\text { where this } \\
\text { contaminant } \\
\text { SOURCE best } \\
\text { fits? }\end{array}$ & $\begin{array}{l}\text { Use this picklist to document the types of contaminant sources } \\
\text { (point and nonpoint) that are described in the reference. If the } \\
\text { reference does not describe a contaminant source, do not make a } \\
\text { selection from the picklist. Example: Accidents, Air Pollution, } \\
\text { Spills, Contaminated sediments/soils, Petroleum evaporation/ } \\
\text { production. }\end{array}$ & $\begin{array}{l}\text { Picklist: Up to } 70 \\
\text { selections. Defaults to } \\
\text { "Not Applicable." }\end{array}$ \\
\hline $\begin{array}{l}\text { Contaminant } \\
\text { classifications } \\
\text { linked to this } \\
\text { source }\end{array}$ & $\begin{array}{l}\text { Use this picklist to document the contaminant categories that are } \\
\text { described in the reference. If the referen.ce does not describe a } \\
\text { contaminant category, do not make a selection from the picklist. } \\
\text { Erample: Airborne Gaseous Products, Airborne Particulates, } \\
\text { Heavy Metals, Petroleum Products }\end{array}$ & $\begin{array}{l}\text { Picklist: Up to } 64 \\
\text { selections. Defaults to } \\
\text { "Not Applicable." }\end{array}$ \\
\hline \multicolumn{3}{|c|}{ Pathways That Allow Contaminant(s) to Reach the Trust Area } \\
\hline Surface Water & $\begin{array}{l}\text { Pathways described in Section 5: Pathways, are presented in this } \\
\text { record as a picklist. Select the pathway(s) by which contaminants } \\
\text { released from the facility are conducted to the refuge. Example: } \\
\text { None Selected. }\end{array}$ & $\begin{array}{l}\text { Picklist: Multiple } \\
\text { pathways can be } \\
\text { selected. }\end{array}$ \\
\hline Ground Water & $\begin{array}{l}\text { Pathways described in Section } 5 \text { are presented in this record as a } \\
\text { picklist. Select the pathway(s) by which contaminants released from } \\
\text { the facility are conducted to the refuge. Example: Cedar Hills } \\
\text { Sandstone Aquifer..... Kjowa Shale Aquitard.. }\end{array}$ & $\begin{array}{l}\text { Picklist: Multiple } \\
\text { pathways can be } \\
\text { selected. }\end{array}$ \\
\hline Air & $\begin{array}{l}\text { Eight cardinal directions presented in a picklist. Select the wind } \\
\text { direction by which contaminants released from the facility may } \\
\text { reach refuge. Example: Northwest. }\end{array}$ & $\begin{array}{l}\text { Picklist: Multiple } \\
\text { pathways can be } \\
\text { selected. }\end{array}$ \\
\hline Biotic & $\begin{array}{l}\text { Potential biological contaminant vectors from Section 5: Pathways, } \\
\text { are listed here. Select those organisms that may transport } \\
\text { contaminants from the site to the refuge. Example: Great Blue } \\
\text { Herons, Migratory Ducks, Neo-tropical songbirds. }\end{array}$ & $\begin{array}{l}\text { Picklist: Multiple species } \\
\text { can be selected. }\end{array}$ \\
\hline Comments & $\begin{array}{l}\text { Describe characteristics about this facility that may have particular } \\
\text { relevance to the contaminant assessment. Enter any ancillary } \\
\text { information that is not covered adequately by the picklist of } \\
\text { contaminants. Comments may include water or air quality } \\
\text { parameters that are likely to be impacted by the operation of the } \\
\text { facility. Erample: A spill from this facility could enter the } \\
\text { groundwater and potentially affect the Refuge. Other paths of } \\
\text { contamination would be animals (primarily birds) feeding in } \\
\text { contaminated areas around the facility and bringing } \\
\text { contamination back to the Refuge either on their bodies or by } \\
\text { transporting contaminated food to the Refuge. Due to the } \\
\text { distance between the Refuge and the facility this scenario is not } \\
\text { highly likely. This facility is involved in petroleum distribution. }\end{array}$ & Character limit: 2,000 \\
\hline $\begin{array}{l}\text { Contacts linked } \\
\text { to this site }\end{array}$ & $\begin{array}{l}\text { Provides a picklist of contacts previously entered. Select name of } \\
\text { individual with knowledge about the source. Enter new names in } \\
\text { the fields below. Example: Ivan Wagner. }\end{array}$ & $\begin{array}{l}\text { Picklist: Defaults to “No } \\
\text { Contact." }\end{array}$ \\
\hline \multirow[t]{2}{*}{ Add new contact } & Surname and title of contact. Example: None added. & Character limit: 40 \\
\hline & Last name of contact. Example: None added. & Character limit: $\mathbf{4 0}$ \\
\hline
\end{tabular}




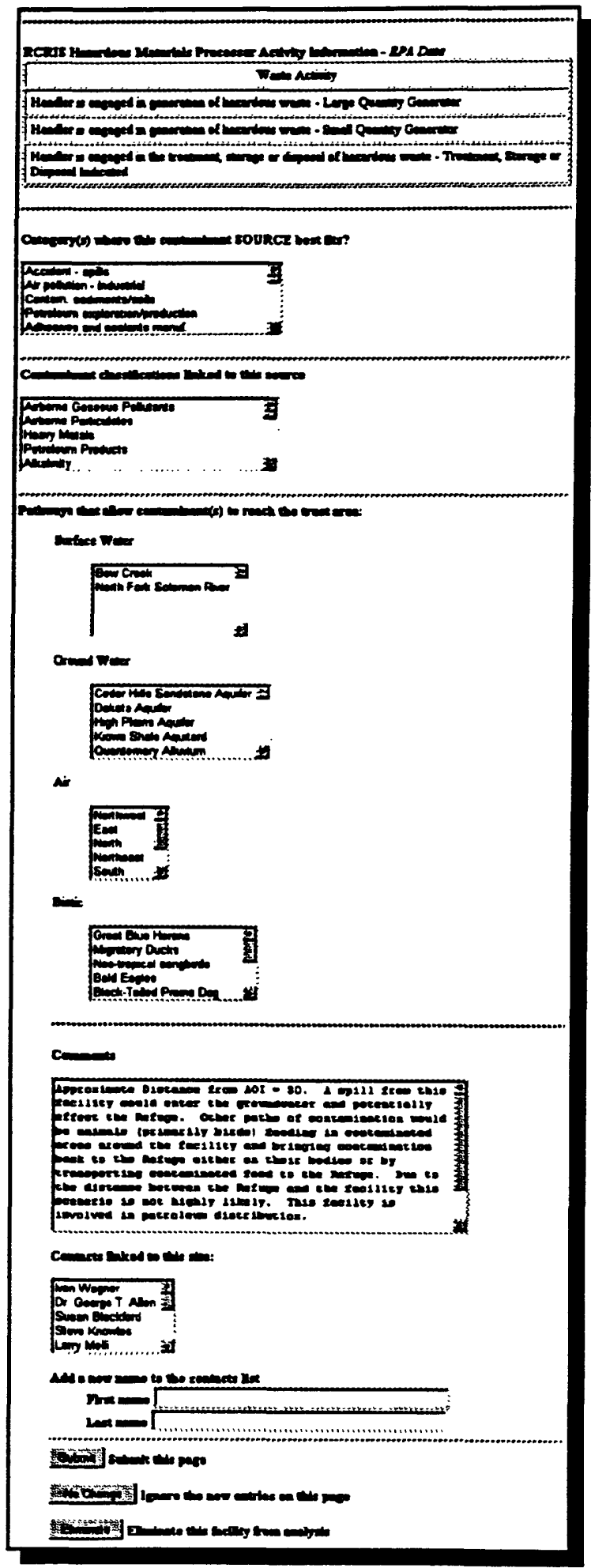

Figure 6.5. Concluded. 
Table 6-6. Field descriptions and examples: Contaminant Source Information - Other Sites.

\begin{tabular}{|c|c|c|}
\hline Field Name & Content Guidance/Erample & Data Entry Tips \\
\hline Name of the area & $\begin{array}{l}\text { Provide descriptive name for the area Example: Adjacent } \\
\text { Agricultural Lands. }\end{array}$ & Character limit: 80 \\
\hline $\begin{array}{l}\text { Location/ } \\
\text { Address }\end{array}$ & $\begin{array}{l}\text { Provide a location relative to the refuge or address for the area. } \\
\text { Example: The adjacent agricultural lands include lands } \\
\text { upstream (south) from the refuge as well as two parcels which } \\
\text { are within refuge boundaries but that are farmed by a private } \\
\text { landowner... }\end{array}$ & Character limit: 2,000 \\
\hline \multicolumn{3}{|c|}{ Latitude } \\
\hline Degrees & $\begin{array}{l}\text { Distance of the area north or south of the equator, measured on a } \\
\text { meridian, expressed in degrees. Erample: } 47 .\end{array}$ & Character limit: 2 \\
\hline Minutes & $\begin{array}{l}\text { Distance of the area north or south of the equator, measured on a } \\
\text { meridian, expressed in minutes. Example: } 1 \text {. }\end{array}$ & Character limit: 2 \\
\hline Seconds & $\begin{array}{l}\text { Distance of the area north or south of the equator, measured on a } \\
\text { meridian, expressed in seconds. Example: } 59 \text {. }\end{array}$ & Character limit: 2 \\
\hline \multicolumn{3}{|c|}{ Longitude } \\
\hline Degrees & $\begin{array}{l}\text { The location of the area in reference to the prime meridian, } \\
\text { expressed in degrees. Example: }-122 \text {. }\end{array}$ & $\begin{array}{l}\text { Character limit: } 3 \\
\text { ("-" in N. America) }\end{array}$ \\
\hline Minutes & $\begin{array}{l}\text { The location of the area in reference to the prime meridian, } \\
\text { expressed in minutes. Example: } 46 .\end{array}$ & Character limit: 2 \\
\hline Seconds & $\begin{array}{l}\text { The location of the area in reference to the prime meridian, } \\
\text { expressed in seconds. Example: } 35 \text {. }\end{array}$ & Character limit: 2 \\
\hline $\begin{array}{l}\text { Is this location } \\
\text { ON or OFF } \\
\text { Interior lands? }\end{array}$ & $\begin{array}{l}\text { Classify area as being located within the refuge boundary or outside } \\
\text { of the boundary. Example: Off. }\end{array}$ & $\begin{array}{l}\text { Radio button. One } \\
\text { selection allowed. }\end{array}$ \\
\hline $\begin{array}{l}\text { Category(s) } \\
\text { where this } \\
\text { contaminant } \\
\text { SOURCE best } \\
\text { fits? }\end{array}$ & $\begin{array}{l}\text { Use this picklist to document the types of contaminant sources } \\
\text { (point and nonpoint) that are described in the reference. If the } \\
\text { reference does not describe a contaminant source, do not make a } \\
\text { selection from the picklist. Example: Agriculture-aerial spray, } \\
\text { drainwater, livestock, Confined Livestock Feeding... }\end{array}$ & $\begin{array}{l}\text { Picklist: Up to } 70 \\
\text { selections. Multiple } \\
\text { selections allowed. } \\
\text { Defaults to "Not } \\
\text { Applicable." } \\
\end{array}$ \\
\hline $\begin{array}{l}\text { Contaminant } \\
\text { classifications } \\
\text { linked to this } \\
\text { source }\end{array}$ & $\begin{array}{l}\text { Use this picklist to document the contaminant categories that are } \\
\text { described in the reference. If the reference does not describe a } \\
\text { contaminant category, do not make a selection from the picklist. } \\
\text { Example: Fecal Coliforms, Organochlorines, Organophosphates, } \\
\text { Other Pesticides }\end{array}$ & $\begin{array}{l}\text { Picklist: Up to } 64 \\
\text { selections. Multiple } \\
\text { selections allowed. } \\
\text { Defaults to "Not } \\
\text { Applicable." } \\
\end{array}$ \\
\hline
\end{tabular}




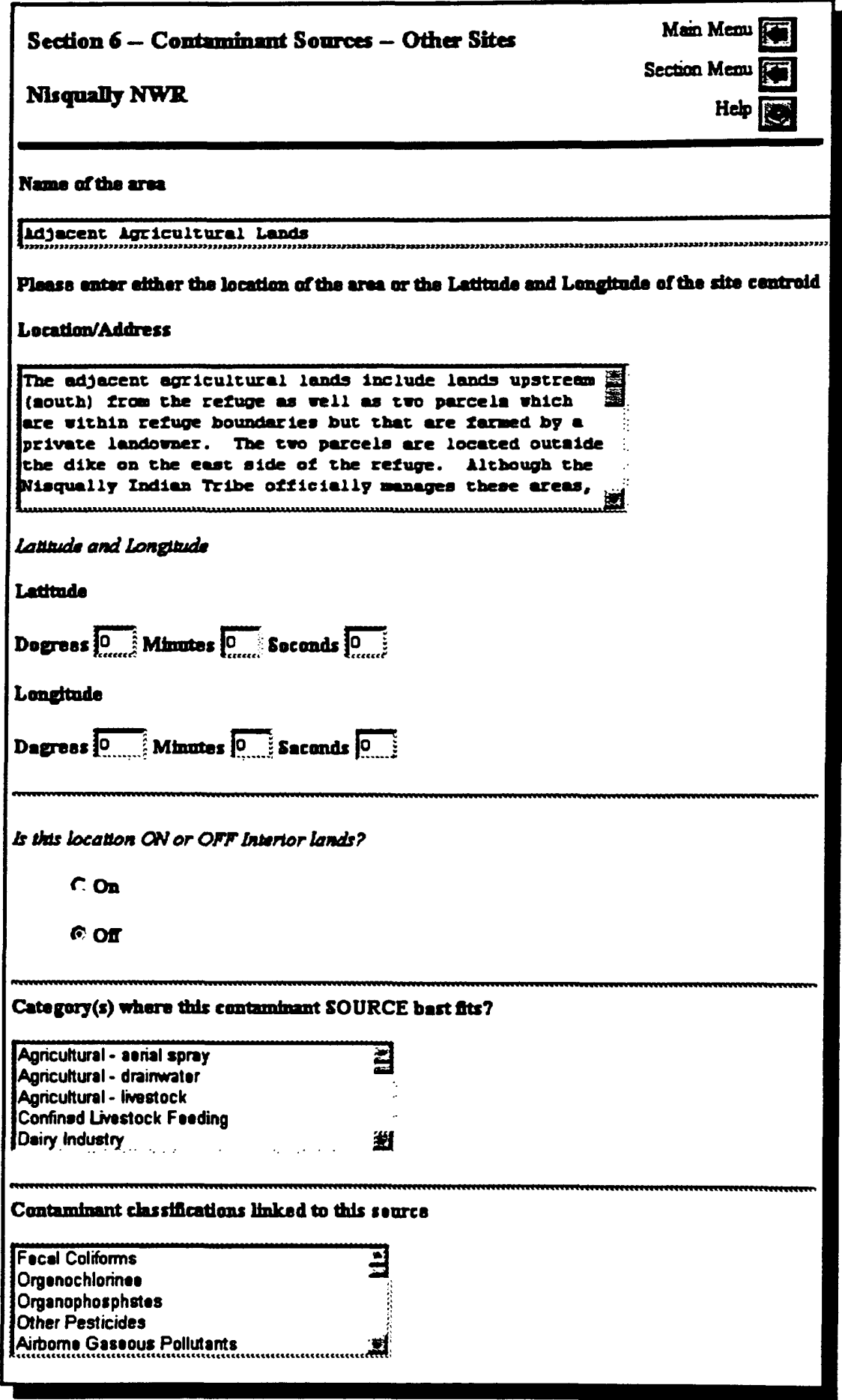

Figure 6-6. Data entry screen: Contaminant Source Information Other Sites. 
Table 6.6. Concluded.

\begin{tabular}{|c|c|c|}
\hline Field Name & Content Guidance/Erample & Data Entry Tips \\
\hline Surface Water & $\begin{array}{l}\text { Pathways described in Section 5: Pathways, are presented in this } \\
\text { record as a picklist. Select the pathway(s) by which contaminants } \\
\text { released from the area are conducted to the refuge. Erample: } \\
\text { HOGUM BAY OF PUGET SOUND, McAllister Creek, } \\
\text { NISQUALLY RIVER, PUGET SOUND \& NISQUALLY } \\
\text { REACH, Red Salmon Creek. }\end{array}$ & Character limit: 2,000 \\
\hline Ground Water & $\begin{array}{l}\text { Pathways described in Section 5: Pathways, are presented in this } \\
\text { record as a picklist. Select the pathway(s) by which contaminants } \\
\text { released from the area are conducted to the refuge. Example } \\
\text { McAllister Springs and Nisqually Groundwater, South Central } \\
\text { Pierce County Aquifer. }\end{array}$ & $\begin{array}{l}\text { Picklist: Multiple } \\
\text { pathways can be } \\
\text { selected. }\end{array}$ \\
\hline Air & $\begin{array}{l}\text { Eight cardinal directions presented in a picklist. Select the wind } \\
\text { direction by which contaminants released from the area may reach } \\
\text { refuge. Example: Northeast, South, Southwest. }\end{array}$ & $\begin{array}{l}\text { Picklist: Multiple } \\
\text { pathways can be } \\
\text { selected. }\end{array}$ \\
\hline Biotic & $\begin{array}{l}\text { Potential biological contaminant vectors from Section 5: Pathways, } \\
\text { are listed here. Select those organisms that may transport } \\
\text { contaminants from the area to the refuge. Erample: No species } \\
\text { listed in Section 5. }\end{array}$ & $\begin{array}{l}\text { Picklist: Multiple species } \\
\text { can be selected. }\end{array}$ \\
\hline Comments & $\begin{array}{l}\text { Describe characteristics about this area that may have particular } \\
\text { relevance to the contaminant assessment. Enter any ancillary } \\
\text { information that is not covered adequately by the picklist of } \\
\text { contaminants. Comments may include water or air quality } \\
\text { parameters that are likely to be impacted by the activities at the } \\
\text { area. Erample: Although contaminants associated with the } \\
\text { haying practice within refuge boundaries have not been } \\
\text { documented, they are suspected. These and other adjacent } \\
\text { farnlands are used to grow crops and are subject to a wide } \\
\text { range of fertilizer and pesticide treatments, including some } \\
\text { pesticides, such as aldicarb and parathion not currently allowed } \\
\text { on refuge lands. Aerial drift of pesticides from these lands or } \\
\text { leaching to irrigation waters on refuge lands may occur. Finally, } \\
\text { fecal coliform from upstream aquaculture and agricultural } \\
\text { practices have been documented in McAllister Creek....Hunting } \\
\text { is still allowed on adjacent Washington Department of Fish and } \\
\text { Wildlife thus the refuge probably has a legacy of lead shot. } \\
\text { However, lead shot use ended in the mid-eighties and this } \\
\text { potential source of contamination should be diminishing. } \\
\text { Wildlife found dead should always be examined for lead shot in } \\
\text { old wounds or in digesta due to the hunting allowed on adjacent } \\
\text { lands. Finally, previous land use of refuge lands include } \\
\text { agricultural practices, thus pesticide residues within refuge } \\
\text { lands especially in the old orchard and within the diked areas } \\
\text { are of possible concern. }\end{array}$ & Character limit: 2,000 \\
\hline $\begin{array}{l}\text { Contacts linked } \\
\text { to this site }\end{array}$ & $\begin{array}{l}\text { Provides a picklist of contacts previously entered. Select name of } \\
\text { individual with knowledge about the source. Enter new names in } \\
\text { the fields below. Erample: Bill Cleland,.....Jay Davis. }\end{array}$ & $\begin{array}{l}\text { Picklist: Defaults to "No } \\
\text { Contact." }\end{array}$ \\
\hline \multirow[t]{2}{*}{ Add new contact } & Surname and title of contact. Example: None added. & Character limit: 40 \\
\hline & Last name of contact. Example: None added. & Character limit: 40 \\
\hline
\end{tabular}




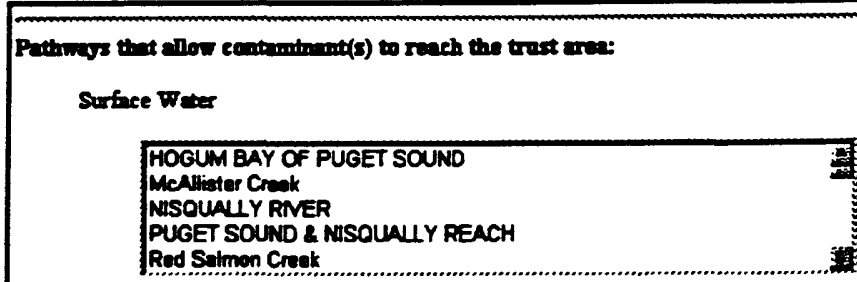

Cround Water

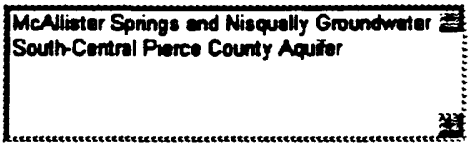

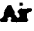

\begin{tabular}{|c|}
\hline $\begin{array}{l}\text { Northeast } \\
\text { South } \\
\text { Southmet } \\
\text { Eest } \\
\text { North }\end{array}$ \\
\hline
\end{tabular}

Biotic

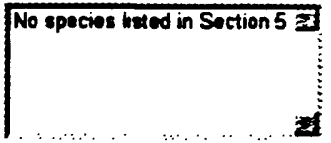

Commeres

Athough coateninants aseoclated fith the hapiag

prectice olth in refuoe boundarien hme not been

docuneated, they are suopeoted. These and other

adjecenc remiands are used to grov crope and are

subject to a vide rapo el lertilizar and pesticide

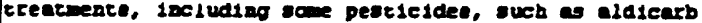

and parathion not currencly allowed on resuge lands.

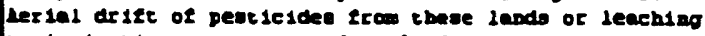

to 1 rzigetion meters on resuge lands mo oocur.

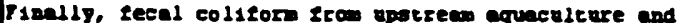

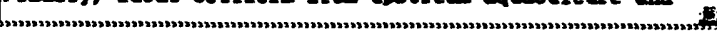

Contacts linked to this the:

Bill Claland
Nenotte Soto
Jeen Takokewn
Bob Woolrich
Jay Devis

Add a new nome to the contuets Hot

First anome

Last nine

stoming subnet this page

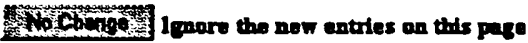

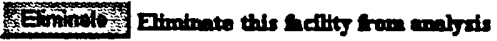

Figure 6.6. Concluded. 
Chapter 1: Field Reconnatissance.

Section 1. Overview
The purpose of this section is to document information obtained through conducting site visits to areas within the AOI that are of particular significance to the assessment. Information gathered during site visits or through review of remotely-sensed images is summarized on data entry screens in this section. Additionally, they may lead to the discovery of undocumented information or the observation of unexpected activities (i.e., shipments of hazardous materials along nearby transportation corridors).

Site visits often provide opportunities to field-check information compiled in earlier portions of the assessment. Conducting an on-theground field reconnaissance may not always be possible, especially in remote areas (i.e., Alaska). In such cases, aircraft flyovers and the use of satellite images or aerial photography should be considered.

Examples of useful sources of information that can assist in or, in some cases, substitute for site visits include USGS 7.5' topographic and 1:250,000 scale land use maps; USFWS National Wetland Inventory maps; orthophoto quadsheets, aerial, and satellite photographs.

Occasionally, records of field reconnaissance visits conducted for purposes other than the CAP are available and may provide the Primary Investigator with valuable information concerning conditions at the site. Where appropriate, summaries of previous reconnaissance visits should be documented in this step of the process.

In some cases, it may be advisable to document conditions during a site visit by using a video or still camera. Video records and still photographs can provide a powerful baseline documentation format that can be used to assess changes to the area and may have relevance to future damage assessment efforts. If using a still camera, record the dates and locations of photographs. Using the audio channel to document the time, date, names of the personnel present, and to record impressions of the area, can provide a more thorough record of the visit. Record the location where the photographs or video cassette film are stored (along with cassette and counter numbers) in the "Comments" field of this sections' data entry screen. The Primary Investigator should ensure that such documentation is archived for possible conversion to digital format and inclusion in the CAP database in the future.

Field reconnaissance visits can be made to potentially any location deemed relevant to the assessment. However, legal considerations may restrict access to privately-owned agricultural or commercial facilities. All site visits should be conducted in accordance with safety and agency standards. On-refuge visits should be coordinated with management staff. Visiting off-refuge locations 
Suggested On-Refuge Areas for Site Visits

Suggested Off-Refuge Areas for Site Visits
Section 2. Data Management System Operation may require permission from landowners or facility managers. When scheduling site visits, keep in mind that conditions at the site are likely to undergo seasonal, and even daily, variations. Depending on the type of site, visits should be scheduled so as to observe conditions at times of particular interest, such as periods of reproductive, foraging, or migratory activity.

Typically, on-refuge field reconnaissance visits will focus on the types of areas described in the following list:

- known contaminant-impacted areas

- suspected contaminated areas, including abandoned dump sites and aircraft landing strips

- areas where fertilizers or pesticides are used or mixed for application

- areas where surface water is entering the unit

- areas with sensitive habitats and/or species

- areas that could function as reference or comparison sites

- potential or current monitoring locations (air, ground water, surface water, biota, sediment)

The following list provides examples of the types of off-refuge areas that may warrant a site visit:

- local areas important to trust resources identified in Section 4

- surface water and runoff areas that flow onto the refuge

- areas where fertilizers or pesticides are used

- areas where potential contaminant sources are located

- areas that could function as reference or comparison sites

- potential or current monitoring locations (air, surface water, biota, sediment)

Information required for this section is recorded on as many records as necessary. New records are added by clicking on the button titled "Add New Reconnaissance Information." Initially, the names of areas identified in Section 4: Local Off-Interior Areas Important to Trust Resources are presented in the section menu under the heading "Areas Not Yet Addressed: Important Off-Interior Areas Not Listed As Contaminant Sources." In addition, the names of all facilities reviewed and retained in Section 6: Contaminant Source Information are listed on the section menu. Selecting any of these hypertext links opens a new record and enters the name of the area or selected facility in the "Name of Area" field. The system does not upload any additional facility-specific contaminant information into the record. 
Selecting and entering information on any of the hypertext-linked sites moves the name of the facility to a position on the section menu under "Areas Visited."

The names of contacts listed on the data entry screen for this section are derived from those entered in Section 2: Background Information - Contacts. The names added in this section are automatically appended to the picklist of individuals recorded in Section 2: Background Information - Contacts . If multiple contact names must be entered for an area, enter the first and last name and submit the record. Select the same record from the section menu and enter the additional name in the contact fields and submit the record again. This process can be repeated as often as necessary. To provide information on any new contacts entered on this form, return to the Main Menu, and select Section 2: Background Information: Contacts. Select the name from the picklist and enter any relevant information into the record.

The picklist of major habitat types contains the same options as those provided in Section 3: Assessment Considerations - Land Cover/Land Use. 


\section{Section 3. Guidance for Data Entry and Analysis: Field Reconnaissance}

Table 7-1. Field descriptions and examples: Field Reconnaissance.

\begin{tabular}{l|l|l}
\hline \multicolumn{1}{c|}{ Field Name } & \multicolumn{1}{|c|}{ Content Guidance/Example } & \multicolumn{1}{|c}{ Data Entry Tips } \\
\hline Name of area & Enter the name of site being visited. Example: The Bluffs. & Character limit: 200 \\
\hline $\begin{array}{l}\text { Date(s) of field } \\
\text { reconnaissance }\end{array}$ & $\begin{array}{l}\text { Enter the date(s) that the site was visited. Example: March 10, } \\
1999 .\end{array}$ & Character limit: 40 \\
\hline $\begin{array}{l}\text { Reconnaissance } \\
\text { by }\end{array}$ & $\begin{array}{l}\text { Select the names of individuals making the site visit from the } \\
\text { picklist. If individual is not listed, enter it in the following fields. } \\
\text { Erample: Jay Davis, Nanette Seto. }\end{array}$ & $\begin{array}{l}\text { Picklist: Derived from } \\
\text { Section 2: Contacts. } \\
\text { Multiple selections } \\
\text { allowed. Defaults to "No } \\
\text { Selection." }\end{array}$ \\
\hline
\end{tabular}

Enter Name If Not in List

\begin{tabular}{l|l|l}
\hline First name & Enter the surname of contact. Example: None. & $\begin{array}{l}\text { Character limit: 40 Adds } \\
\text { name to Section 2: } \\
\text { Contacts list. }\end{array}$ \\
\hline Last name & Enter the last name of contact. Example: None. & $\begin{array}{l}\text { Character limit: 40 Adds } \\
\text { name to Section 2: } \\
\text { Contacts list. }\end{array}$ \\
\hline $\begin{array}{l}\text { Description of } \\
\text { area and } \\
\text { importance to } \\
\text { study }\end{array}$ & $\begin{array}{l}\text { Document the extent of the site and describe characteristics about } \\
\text { this site that may have particular relevance to the contaminant } \\
\text { assessment (topography, hydrology, gradient/proximity to the } \\
\text { refuge). Enter any ancillary information that explains why this site } \\
\text { was selected for a visit. Note unusual numbers of dead trees or } \\
\text { uncharacteristically barren or discolored patches of ground. } \\
\text { Example: We visited the bluffs, which is an elevated (200 to 300 } \\
\text { feet above sea level) forest located on the west side of the refuge. } \\
\text { This southwestern boundary of the refuge is not fenced and } \\
\text { there are new residential communities being built directly next } \\
\text { to refuge lands. }\end{array}$ & Character limit: \\
\hline
\end{tabular}




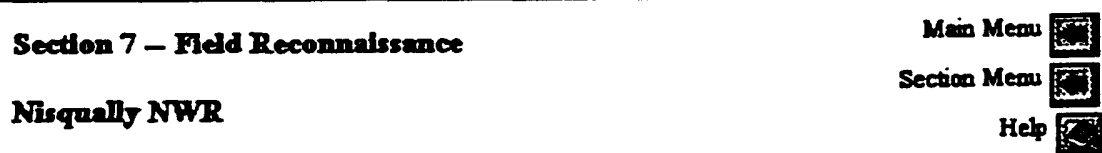

Name of the aree

The Bluets

Data(s) of Flold Rocomadsenes Earch 10, 1999

Recomonistance by:

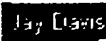

il thiolte cion

Bill Clelend

Willard Bill' Heseetbart 8

Brenden MeForiand

Entar mane tr aot in Hrt:

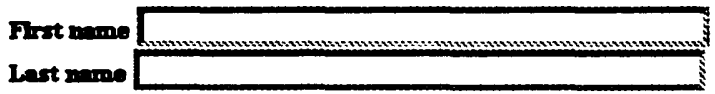

Descrtption of area end tomportance to study:

De visited the bluefs which 18 an eleveted 1200 to 300

leet above aed level) loreat located on the veat alde

or the refuge. This woutbreatera boundary or the

refuge 1s not fenced and chere are net realdenc1el

comminities belng bullt directly next to refuge lands.

Relovene to contantmant asses snont

Due to rapid realdeaciel (bousing comminteles) and

recreationel (0ols couraes in particular) development

there 18 oreat concern that these nev activities any

erfect the refuoe. Iany of the houses are on a aptic

- yotere and aloo bave retention pond to collect and

treat storm vater zun-o1f. There 1 a concers that as

the realdential aree grow and ajes, Ialling oeptic

egecene and over loaded ecorm vacer retent108 ponds $121 \mathrm{l}$

releese conteminante direet 1 g dow hill 1 ato the

refuge. Tuture plans of a veserater creacient

Figure 7-1. Data entry screen: Field Reconnaissance. 
Table 7-1. Concluded.

\begin{tabular}{l|l|l}
\hline \multicolumn{1}{c|}{ Field Name } & \multicolumn{1}{c}{ Content Guidance/Example } & \multicolumn{1}{c}{ Data Entry Tips } \\
\hline $\begin{array}{l}\text { Flora and/or } \\
\text { fauna seen } \\
\text { during the } \\
\text { reconnaissance }\end{array}$ & $\begin{array}{l}\text { Describe significant plant communities, terrestrial, and avian } \\
\text { species and invertebrate populations seen in the area during the } \\
\text { visit. Identify species that might potentially be susceptible to } \\
\text { contaminant effects. This field contains the direction of the facility } \\
\text { relative to the refuge. It is calculated by the data management } \\
\text { system. Example: Northeast. }\end{array}$ & Character limit: 2,000 \\
\hline $\begin{array}{l}\text { Select the major } \\
\text { habitat types/ } \\
\text { land uses that } \\
\text { apply to this area }\end{array}$ & $\begin{array}{l}\text { Select the land/cover categories from the picklist seen during the } \\
\text { visit. Example: Deciduous forest, other habitat. }\end{array}$ & $\begin{array}{l}\text { Picklist: Up to 27 } \\
\text { selections. Multiple } \\
\text { selections allowed. } \\
\text { Defaults to "None." }\end{array}$ \\
\hline
\end{tabular}


Plare endor Fuen seen during the recoundszance:

This part of tbe cour ves conducted via a vehicle, thus in

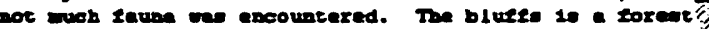

ox dougles 21r, wertern cedar and restern hemlock.

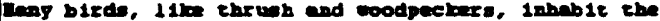

aree as vell as ocber rildiles epecies including

rodemes and deer.

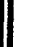

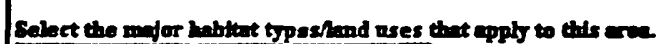

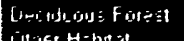

iit ifer H:bin: 1

Agnculturd Lande

Deciduous Dwart Shrubland

Deciduous Shrublend

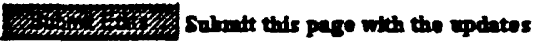

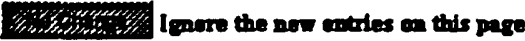

Delece this roeend

Figure 7-1. Concluded. 
Gapter S. P otentially Eontaminated Arieas:

\section{Section 1. Overview}

Possible PCA Locations
Section 8 of the data management system is used to identify areas on the refuge where field sampling could be conducted to confirm the presence and/or effects of contaminants. These potentially contaminated areas (PCAs) are associated with pathways which are likely to conduct pollutants released from point and nonpoint sources within the area of interest.

Ideally, the PCA is a general area where contaminants or their effects are likely to be observed soon after they move onto the refuge or as they move away from the source on the refuge. There may be multiple PCAs for a refuge, depending on the contaminants and transport pathways in the AOI. For those contaminants and pathways that originate outside the refuge boundary, the locations where the pathways enter the refuge is a good place to start when considering the appropriate location of a PCA. Areas downstream, downwind, or downgradient of on-refuge contaminant sources may also be identified as PCAs. The Primary Investigator should purposefully bias the selection of PCAs to those locations that are most likely to contain elevated concentrations of suspected contaminants, thereby permitting earlier detection of contaminant-related effects compared to randomly selected refuge sites. Sampling at these areas will not provide an indication of the average conditions of the refuge. Rather, they will represent potential hot spots of contamination or effect.

The following are examples for possible PCA locations:

- major inlets/outlets to or from a body of water

- locations downstream/downgradient/ from significant waste discharges

- primary airborne particulate deposition zones

When selecting PCAs, the following questions should be taken into account.

- Is the area a likely location for contaminants to be present in elevated concentrations?

- Are appropriate media and environmental variables present to sample for contaminants?

- Do potentially sensitive or surrogate species use the area?

- Is there reasonable access to the area?

- Can multiple contaminants or environmental variables be measured at this location? 
- Is the area sufficiently homogeneous so that a low number of samples is adequate to generate a measure of central tendency with an acceptable level of confidence?

To facilitate this step, the data management system provides a valuable summary of retained contaminant sites organized by transport pathway. The summary can be accessed by clicking on the hypertext link "Contaminant Sites Summarized by Transport Pathway" located at the bottom of Section 6 on the Main Menu. The list of transport pathways is derived from user input and the data field titled "Receiving Water" contained on the PCS/NPDES and TRI facility records. The Primary Investigator should carefully review this summary with the objective of prioritizing the pathways on which the greatest number of contaminant sources are located. Pathways not associated with significant contaminant sources are unlikely to pose ecological risks to the refuge. Likewise, some pathways identified in the list may not convey contaminants to the refuge, owing to their location and direction of flow in the AOI.

The data management system also provides a series of maps that illustrate the boundary of the refuge in relation to the surface water and air AOI. The maps can be accessed by clicking on the "View Maps of the Area of Interest" hypertext link located at the bottom of the Main Menu. These maps can be downloaded off the system by placing the cursor on the image and clicking the right mouse button. This will open a dialog box. Scroll down the menu in the dialog box and click on the "Save As" option or its equivalent. In the Save As box, select the "GIF" file option and designate a directory in which to save the image.

While a useful starting point, the maps provided by the data management system may not provide sufficient detail for accurately delineating PCAs. Maps obtained from the refuge or other sources may be necessary to complete this step in the process. Due to the spatial nature of this step, it is strongly recommended that the Primary Investigator obtain either digital or hardcopy maps of the appropriate scale and actually delineate a boundary around the area that represents the PCA. The boundary should be drawn so that it encompasses the locations where optimal sampling activities are most likely to identify contaminant presence or effects. Identify this mapped PCA with an identifying number and complete a record for each area. The type of map used and its location should be recorded in the "Notes" box on the section menu screen for future reference.

After identifying the PCAs, the Primary Investigator should document the selection by completing a data entry screen for each location. Obviously, not all identified areas will be equally 
Contamination Level I

Contamination Level 2 contaminated. An important step in completing the record is categorizing the contamination level at the PCA. Categorizing the PCAs will help the Primary Investigator target high priority areas for field sampling in the event that contaminant investigations are warranted to evaluate risks revealed through the retrospective analysis. The Primary Investigator should use the following definitions when assigning a contamination level to each PCA.

Known contaminant sources and documented contamination problems and/or habitat degradation.

- Contaminant presence and effects have been identified and documented at this location.

- Contaminant is present and is a threat to the system and/or humans.

- Significant effects to the system have been observed (dieoffs, morphological/physiological/behavioral effects, habitat degradation, etc.). However, the specific cause(s) might not be known.

- Regulatory levels have been reached for a contaminant or a contamination event has occurred to initiate mitigative/ remedial actions or additional studies.

- A contaminant problem has been identified at this location and mitigative or remediation measures have been implemented that are likely to resolve the problem. This situation still requires special studies or long-term monitoring to verify that the mitigation/ remediation activities are effective.

Known contaminant sources and contaminant presence, no documented contaminant problems or habitat degradation.

- Contaminants very likely (or known) to exist or to be moving to this location, but a specific problem has not been identified.

- Contaminant sources exist upstream (upgradient, upwind) within close proximity to or on the refuge.

- Regulatory requirements relevant to monitoring are not being adequately addressed at this location. 
Contamination Level 3

Contamination Level 4

Section 2. Data

Management System Operation
Known contaminant sources, suspected contaminant presence, no documented contaminant problems or habitat degradation.

- Potential contaminant sources exist:

- Suspected sources exist on- or off-refuge and transport pathways have been identified to this location. However, contaminants have a low probability of reaching this site and affecting the system.

No known contaminant sources other than global atmospheric input and no known habitat degradation.

- Relatively uncontaminated location intersected by a transportation route.

- No known or suspected contaminant sources (other than those associated with the transportation route).

- Transportation route (railway, highway, navigation channel) is upstream, upwind, or upgradient and is known as a route for carriers of various hazardous substances.

- No known degradation of the resource. However, future spills at the site are a serious concern.

Information required for this section is recorded on as many records as necessary. New records are added by clicking on the button titled "Add New PCA Information." The picklists of contaminant classifications are the same as provided in Section 6: Contaminant Information and Section 9: Areas Subject to Spills. The picklists of pathways are derived from those entered in Section 5: Transport Pathways. 


\section{Section 3. Guidance for Data Entry and Analysis: Potentially Contaminated Areas}

Table 8-1. Field descriptions and examples: Potentially Contaminated Areas.

\begin{tabular}{c|l|c}
\hline Field Name & \multicolumn{1}{|c|}{ Content Guidance/Erample } & Data Entry Tips \\
\hline Site Identifier & $\begin{array}{l}\text { Enter a descriptive identifier for the area. Erample: Nisqually } \\
\text { Delta and its Tributaries (Nisqually River, McAllister and Red } \\
\text { Salmon Creeks) }\end{array}$ & Character limit: 80 \\
\hline
\end{tabular}

Location - Enter Information for at Least One

\begin{tabular}{|c|c|c|}
\hline $\begin{array}{l}\text { Location/ } \\
\text { Address }\end{array}$ & $\begin{array}{l}\text { Enter a description of the area and its general extent and relation to } \\
\text { the refuge. Erample: Together with McAllister and Red Salmon } \\
\text { Creeks, the Nisqually River forms one of the largest remaining } \\
\text { undisturbed estuaries in Washington. Three waterways, the } \\
\text { Nisqually River (in the center of the refuge) and the Red Salmon } \\
\text { (on the eastern boarder of the refuge) and McAllister (on the } \\
\text { western boarder of the refuge) Creeks, come together on the } \\
\text { refuge and open into the south end of Puget Sound forming a } \\
\text { large undisturbed estuary/delta, habitat that is sparse in the } \\
\text { Puget Sound Region. }\end{array}$ & $\begin{array}{l}\text { Character limit: } \\
\text { Unlimited }\end{array}$ \\
\hline
\end{tabular}

\section{UTM Coordinates}

\begin{tabular}{|c|c|c|}
\hline $\mathrm{x}$ & $\begin{array}{l}\text { UTM X coordinate (easting) that in conjunction with the UTM Y } \\
\text { coordinate and UTM zone identifies the areas centroid. Example: } \\
723000 \text {. }\end{array}$ & $\begin{array}{l}\text { Character limit: } 6 \text {. No } \\
\text { commas. }\end{array}$ \\
\hline $\mathbf{Y}$ & $\begin{array}{l}\text { UTM Y coordinate (Northing) that in conjunction with the UTM X } \\
\text { coordinate and the UTM zone identifies the areas centroid. } \\
\text { Example: } \mathbf{4 5 4 5 2 4 0 .}\end{array}$ & $\begin{array}{l}\text { Character limit: } 7 \text {. No } \\
\text { commas. }\end{array}$ \\
\hline UTM Zone & $\begin{array}{l}\text { UTM zone that in conjunction with the UTM X and Y coordinates } \\
\text { identifies the areas centroid. Erample: UTM ZONE: } 13 \text {. }\end{array}$ & Character limit: 2 \\
\hline \multicolumn{3}{|c|}{ Latitude } \\
\hline Degrees & $\begin{array}{l}\text { Distance of the areas centroid north or south of the equator, } \\
\text { measured on a meridian, expressed in degrees. Example: } 47 .\end{array}$ & Character limit: 2 \\
\hline Minutes & $\begin{array}{l}\text { Distance of the areas centroid north or south of the equator, } \\
\text { measured on a meridian, expressed in minutes. Example: } 11 .\end{array}$ & Character limit: 2 \\
\hline Seconds & $\begin{array}{l}\text { Distance of the areas centroid north or south of the equator, } \\
\text { measured on a meridian, expressed in seconds. Example: } 8 \text {. }\end{array}$ & Character limit: 2 \\
\hline \multicolumn{3}{|c|}{ Longitude } \\
\hline Degrees & $\begin{array}{l}\text { The location of the areas centroid in reference to the prime } \\
\text { meridian, expressed in degrees. Example: } \mathbf{- 1 2 2} \text {. }\end{array}$ & $\begin{array}{l}\text { Character limit: } 3 . \\
\text { ("-" in N. America) }\end{array}$ \\
\hline Minutes & $\begin{array}{l}\text { The location of the areas centroid in reference to the prime } \\
\text { meridian, expressed in minutes. Example: } 35 \text {. }\end{array}$ & Character limit: 2 \\
\hline Seconds & $\begin{array}{l}\text { The location of the areas centroid in reference to the prime } \\
\text { meridian, expressed in seconds. Example: } 5 \text {. }\end{array}$ & Character limit: 2 \\
\hline
\end{tabular}


Section 8 - Potentialy Contuminated Areas

Nisqually NWR
Min Meous

Section Meow

Help

nise Ideattater:

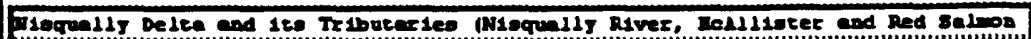

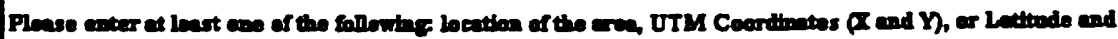
Louctoride

Lecation/Address

Tocetber Fitb Mchliseter and Red Salmon Creelo, the Wisqually River lorm one of the lefoent remining

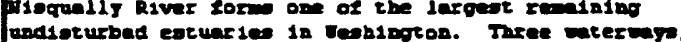
padioturbad escuaries in vooblogton. Three wetervas, tre lad sel won lon the carearn bourder of the refugel and rolllister lob the vetern boarder of the refuge)

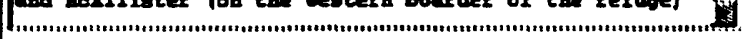

UTM Coonthestes

$\mathbf{~} \mathrm{X}$

Lationde

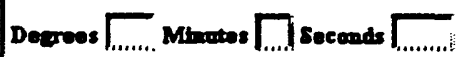

Leanteride

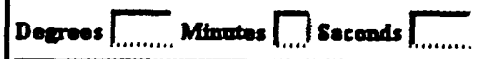

Figure 8-1. Data entry screen: Potentially Contaminated Areas. 
Table 8-1. Continued.

\begin{tabular}{|c|c|c|}
\hline Field Name & Content Guidance/Erample & Data Entry Tips \\
\hline $\begin{array}{l}\text { Description of } \\
\text { site }\end{array}$ & $\begin{array}{l}\text { Document the extent of the PCA and relation to the refuge. Describe } \\
\text { characteristics about this site that may have particular relevance to } \\
\text { the contaminant assessment (topography, hydrology, gradient, } \\
\text { proximity to the refuge). Enter any ancillary information that may } \\
\text { support the selection of the PCA. Erample: Fecal coliform } \\
\text { bacteria have been detected in high enough levels in the water in } \\
\text { and around the refuge especially in McAllister Creek to close } \\
\text { recreational and commercial shellish operations following } \\
\text { substantial storm events. The Washington State Department of } \\
\text { Health is currently involved with monitoring fecal coliform } \\
\text { bacteria in several streams and rivers within the refuge... }\end{array}$ & Character limit: 2,000 \\
\hline $\begin{array}{l}\text { Rationale for } \\
\text { selecting this site }\end{array}$ & $\begin{array}{l}\text { Document significance of the area to the assessment. Describe } \\
\text { particular features of the area that may influence movement of } \\
\text { contaminants from or through the area. Note any die-offs that may } \\
\text { have occurred at the area. Document the extent to which trust } \\
\text { species utilize the area. Summarize any ongoing or historical } \\
\text { investigations or monitoring at the area. Describe concerns about } \\
\text { proposed changes in land use that might influence habitat quality } \\
\text { Example: Due to rapid residential (housing communities) and } \\
\text { recreational (golf courses in particular) development there is } \\
\text { great concern that these new activities may affect the refuge. } \\
\text { Many of the houses are on septic systems and also have retention } \\
\text { ponds to collect and treat storm water run-off. There is a } \\
\text { concern that as the residential area grows and ages, failing } \\
\text { septic systems and overloaded storm water retention ponds will } \\
\text { release contaminants directly down hill into the refuge. }\end{array}$ & Character limit: 2,000 \\
\hline $\begin{array}{l}\text { Select the level } \\
\text { of contamination } \\
\text { that applies to } \\
\text { this area }\end{array}$ & $\begin{array}{l}\text { Based on the guidance in this Chapter, select one of the } 4 \\
\text { contamination levels displayed on the data entry screen that best } \\
\text { describes the PCA. Example: Level } 1 \text { - Known contaminant } \\
\text { sources and documented contamination problems and/or habitat } \\
\text { degradation. }\end{array}$ & $\begin{array}{l}\text { Radio button. Single } \\
\text { selection allowed. }\end{array}$ \\
\hline $\begin{array}{l}\text { Select } \\
\text { contaminant } \\
\text { classifications } \\
\text { linked to this site }\end{array}$ & $\begin{array}{l}\text { Based on a review of information documented in Section } 6 \text { for the } \\
\text { appropriate transport pathway, select the types of contaminants that } \\
\text { are likely to be present at the PCA from the picklist. Example: } \\
\text { Cadmium, Fecal Coliforms, Heavy Metals, Lead Mercury. }\end{array}$ & $\begin{array}{l}\text { Picklist: } 64 \text { selections. } \\
\text { Multiple selections } \\
\text { allowed. Defaults to "No } \\
\text { Selection." }\end{array}$ \\
\hline
\end{tabular}

Select the Pathways That Allow Contaminant(s) to Reach the Area

\begin{tabular}{l|l|l}
\hline Surface Water & $\begin{array}{l}\text { Pathways described in Section 5: Pathways, are presented in this } \\
\text { record as a picklist. Select the pathway(s) by which released } \\
\text { contaminants may reach the PCA. Example: None highlighted. }\end{array}$ & $\begin{array}{l}\text { Picklist. Multiple } \\
\text { pathways can be } \\
\text { selected. }\end{array}$ \\
\hline Ground Water & $\begin{array}{l}\text { Pathways described in Section 5: Pathways, are presented in this } \\
\text { record as a picklist. Select the pathway(s) by which released } \\
\text { contaminants may reach the PCA. Example: None highlighted. }\end{array}$ & $\begin{array}{l}\text { Picklist. Multiple } \\
\text { pathways can be } \\
\text { selected. }\end{array}$ \\
\hline
\end{tabular}




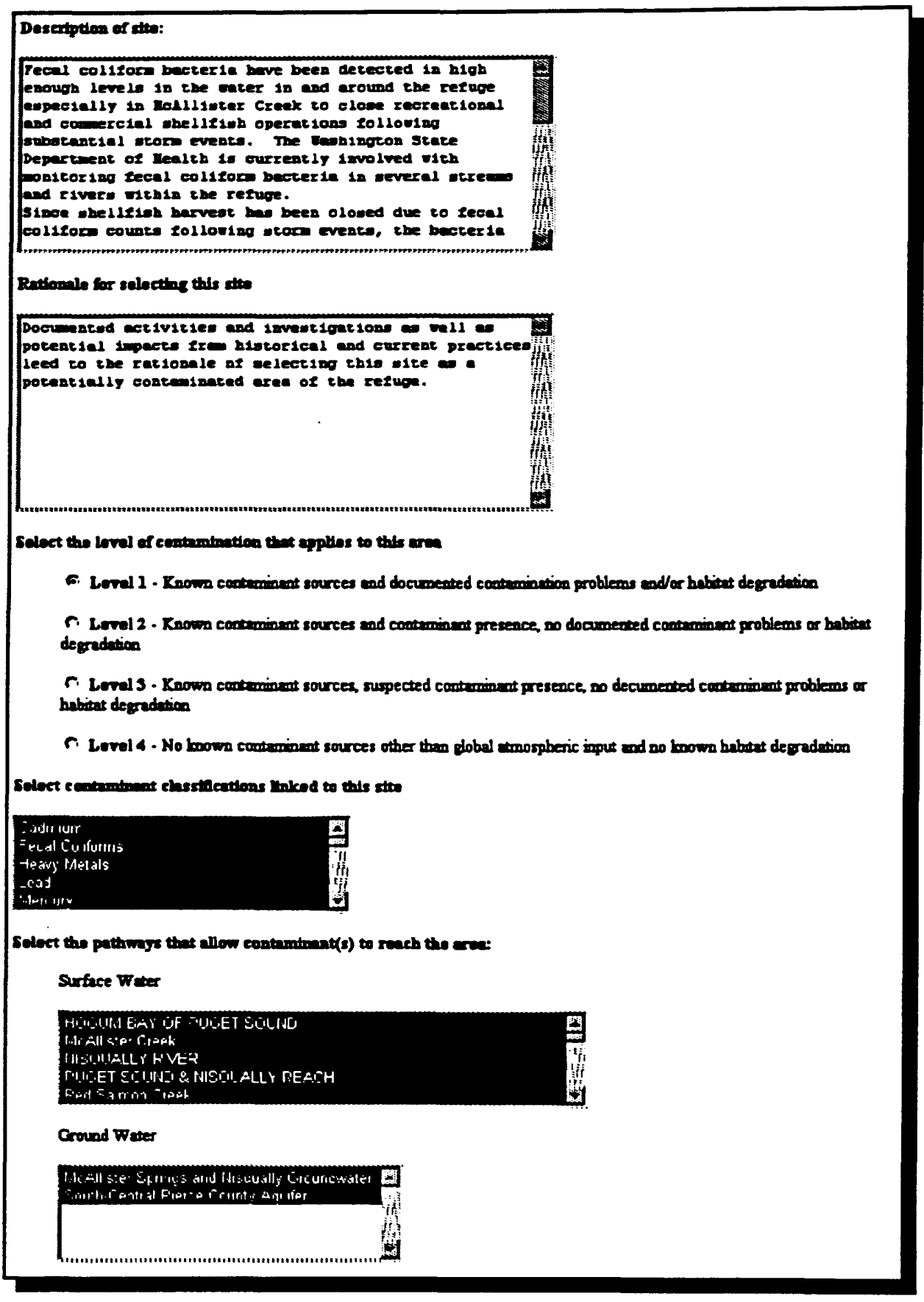

Figure 8.1. Continued. 
Table 8-1. Concluded.

\begin{tabular}{l|l|l}
\hline Field Name & \multicolumn{1}{|c|}{ Content Guidance/Eramples } & \multicolumn{1}{|c}{ Data Entry Tips } \\
\hline Air & $\begin{array}{l}\text { Eight cardinal directions presented in a picklist. Select the wind } \\
\text { direction by which released contaminants may reach the PCA. } \\
\text { Erample: Northeast highlighted. }\end{array}$ & $\begin{array}{l}\text { Picklist. Multiple } \\
\text { pathways can be } \\
\text { selected. }\end{array}$ \\
\hline Biotic & $\begin{array}{l}\text { Potential biological contaminant vectors from Section 5: Pathways } \\
\text { of the data management system are listed here. Select those } \\
\text { organisms that may transport contaminants to the PCA. Example: } \\
\text { No species listed in Section 5. }\end{array}$ & $\begin{array}{l}\text { Picklist. Multiple species } \\
\text { can be selected. }\end{array}$ \\
\hline
\end{tabular}




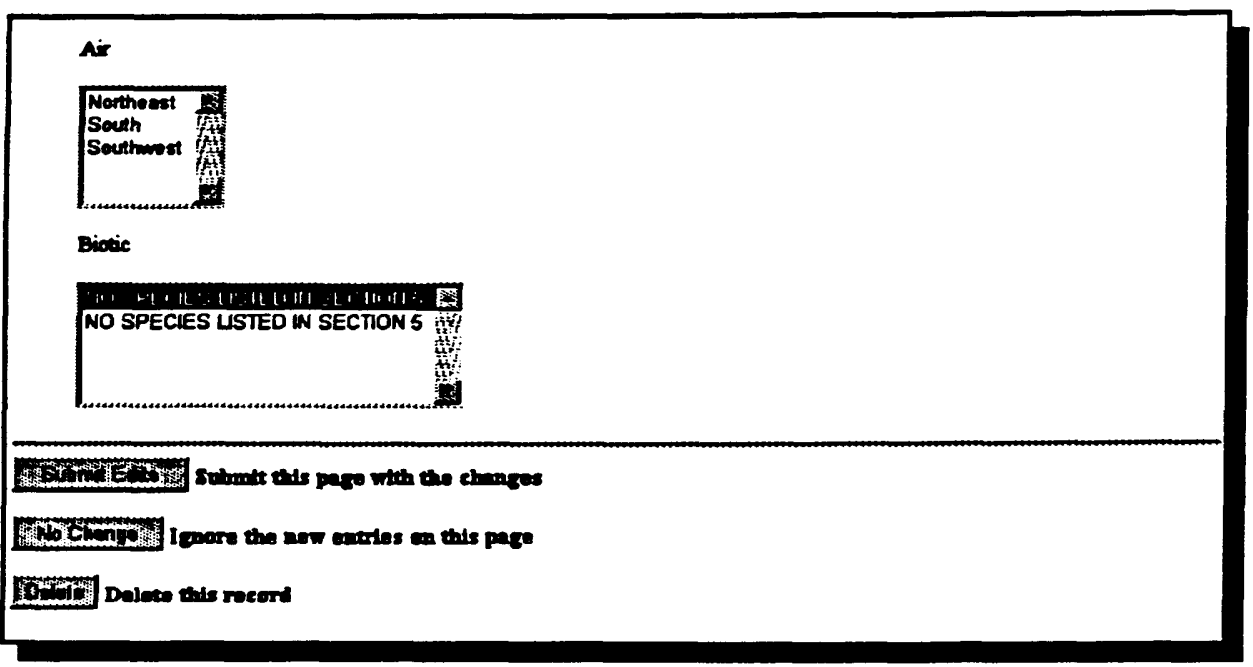

Figure 8-1. Concluded. 
Chrppter 9 Spill Sensitive Areas:
Section 9 of the data management system is used to identify areas on the refuge that may be sensitive to accidental spills of hazardous materials. Large quantities of these materials are routinely transported overland via railroads, highways, and navigation channels.

Frequently, these transportation corridors cross FWS-managed lands or tributaries that flow into them. The purpose of this section is to identify spill sensitive areas (SSAs) on the refuge that may be sensitive to spills and document pre-spill conditions. Data collected at these sites can provide valuable information to support a natural resource damage assessment in the event that a future spill injures FWS trust resources.

Like PCAs, the selection of SSAs are biased and not intended to represent the average conditions on a refuge. Unlike PCAs, they are not selected because they lie along pathways known or suspected to transport contaminants to the refuge. Ideally, these areas would be located where the presence of spilled contaminants or their effects are likely to be observed soon after the spilled material reached the refuge. However, impacts from a spill may not be confined to a discreet area near the boundary of the refuge. Therefore, the Primary Investigator might consider establishing other SSAs at high-value habitats along the pathway. Depending on the location of transportation corridors and pathways, and the number of high-value habitats, multiple SSAs might be identified as part of the assessment.

While the data management system provides some small scale maps of the refuge and surrounding areas, they may not provide sufficient detail for accurately delineating areas subject to spills. It may be necessary to obtain maps from the refuge or other sources to complete this step in the process. The Primary Investigator should review maps of appropriate scale that illustrate topography and major transportation corridors for the refuge and surrounding areas. Only areas located within the boundary of the refuge should be selected. These might include sites located downstream, down-slope, or downwind from major transportation corridors along which hazardous materials are known to be carried.

Due to the spatial nature of this step, it is strongly recommended that the Primary Investigator obtain either digital or hardcopy maps of the appropriate scale and actually delineate these areas. The boundary of the area should be drawn so that it encompasses the optimum locations where sampling activities are most likely to identify the presence or effects from spilled materials. The type of map used and its location should be recorded in the "Notes" field in the Section Menu screen for future reference. 
When selecting SSAs, the following questions should be taken into consideration.

- Is the area sufficiently close to the transportation corridor so that spilled material is likely to reach the refuge in concentrations high enough to cause an effect?

- Are appropriate media and environmental variables present to sample for contaminants?

- Do potentially sensitive or surrogate species use the area?

- Is there reasonable access to the area?

- Is the area sufficiently homogeneous so that a low number of samples is adequate to generate a measure of central tendency with an acceptable level of confidence?

After identifying the SSAs, the Primary Investigator should document the selection by completing a data entry screen for each location. Part of the documentation process requires that the area be assigned a level of contamination. Generally, identified areas will be assigned Contamination Level 4 (no known contaminant sources other than global atmospheric input and no known habitat degradation). However, it is possible that some contamination already is suspected in the area, in which case another level may be appropriate. The following descriptions should be reviewed as the basis for assigning the contamination level for each area.

\section{Contamination Level 1}

Known contaminant sources and documented contamination problems and/or habitat degradation.

- Contaminant presence and effects have been identified and documented at this location.

- Contaminant is present and is a threat to the system and/or humans.

- Significant effects to the system have been observed (dieoffs, morphological/physiological/behavioral effects, habitat degradation, etc.). However, the specific cause(s) might not be known.

- Regulatory levels have been reached for a contaminant or a contamination event has occurred to initiate mitigative/ remedial actions or additional studies.

- A contaminant problem has been identified at this location and mitigative or remediation measures have been implemented that are likely to resolve the problem. This situation still requires special studies or long-term 
Contamination Level 2

Contamination Level 3

\section{Contamination Level 4}

monitoring to verify that the mitigation/remediation activities are effective.

Known contaminant sources and contaminant presence, no documented contaminant problems or habitat degradation.

- Contaminants very likely (or known) to exist or be moving to this location, but a specific problem has not been identified.

- Contaminant sources exist upstream (upgradient, upwind) within close proximity to or on the refuge.

- Regulatory requirements relevant to monitoring are not being adequately addressed at this location.

Known contaminant sources, suspected contaminant presence, no documented contaminant problems or habitat degradation.

- Potential contaminant sources exist.

- Suspected sources exist on- or off-refuge and transport pathways have been identified at this location; however, contaminants have a low probability of reaching this site and affecting the system.

No known contaminant sources other than global atmospheric input and no known habitat degradation.

- Relatively uncontaminated location intersected by a transportation route.

- No known or suspected contaminant sources (other than those associated with the transportation route).

- Transportation route (railway, highway, navigation channel) is upstream, upwind, or upgradient and is known as a route for carriers of various hazardous substances.

- No known degradation of the resource; however, future spills at the site are a serious concern.

Information required for this section is recorded on as many records as necessary. New records are added by clicking on the button titled "Add New PCA Information". The picklists of contaminant classifications are the same as provided in Section 6: Contaminant Information and Section 8: Potentially Contaminated Areas. The list of pathways is derived from those entered in Section 5: Pathways. 


\section{Section 3. Guidance for Data Entry and Analysis: Spill Sensitive Areas}

Table 9-1. Field descriptions and examples: Spill Sensitive Areas.

\begin{tabular}{c|l|c}
\hline Field Name & \multicolumn{1}{|c|}{ Content Guidance/Example } & Data Entry Tips \\
\hline Site identifier & $\begin{array}{l}\text { Enter a descriptive identifier for the area. Erample: Interstate-5 } \\
\text { Corridor. }\end{array}$ & Character limit: 80. \\
\hline
\end{tabular}

Location: Enter information for at least one

\begin{tabular}{l|l|l}
\hline Location/ & $\begin{array}{l}\text { Enter a description of the area and its general extent and relation to } \\
\text { the refuge. Example: The Interstate-5 Corridor is the southern } \\
\text { boundary of the refuge. An area known as the Nisqually River } \\
\text { Overflow is located just under the Interstate-5 corridor along } \\
\text { the southern boundary of the refuge. This freshwater marshy } \\
\text { area under the overpass is being considered as a source of } \\
\text { freshwater for managed wetland areas of the refuge. }\end{array}$ & $\begin{array}{l}\text { Character limit: } \\
\text { Unrestricted }\end{array}$ \\
\hline
\end{tabular}

UTM Coordinates

\begin{tabular}{l|l|l}
\hline $\mathrm{X}$ & $\begin{array}{l}\text { UTM X coordinate (easting) that in conjunction with the UTM Y } \\
\text { coordinate and UTM zone identifies the areas centroid. Example: } \\
\mathbf{7 2 3 0 0 0 .}\end{array}$ & $\begin{array}{l}\text { Character limit: 6. No } \\
\text { commas. }\end{array}$ \\
\hline $\mathrm{Y}$ & $\begin{array}{l}\text { UTM Y coordinate (northing) that in conjunction with the UTM X } \\
\text { coordinate and the UTM zone identifies the areas centroid. } \\
\text { Example: } 4545240 .\end{array}$ & $\begin{array}{l}\text { Character limit: 7. No } \\
\text { commas. }\end{array}$ \\
\hline UTM Zone & $\begin{array}{l}\text { UTM zone that in conjunction with the UTM X and Y coordinates } \\
\text { identifies the areas centroid. Example: 13. }\end{array}$ & Character limit: 2 \\
\hline
\end{tabular}

Latitude

\begin{tabular}{l|l|l}
\hline Degrees & $\begin{array}{l}\text { Distance of the facility north or south of the equator, measured on a } \\
\text { meridian, expressed in degrees. Example: } 47 .\end{array}$ & Character limit: 2 \\
\hline Minutes & $\begin{array}{l}\text { Distance of facility north or south of the equator, measured on a } \\
\text { meridian, expressed in minutes. Example: 11. }\end{array}$ & Character limit: 2 \\
\hline Seconds & $\begin{array}{l}\text { Distance of the facility north or south of the equator, measured on a } \\
\text { meridian, expressed in seconds. Example: } 8 .\end{array}$ & Character limit: 2 \\
\hline
\end{tabular}

Longitude

\begin{tabular}{l|l|l}
\hline Degrees & $\begin{array}{l}\text { Distance of the areas centroid north or south of the equator, } \\
\text { measured on a meridian, expressed in degrees. Example: -122. }\end{array}$ & $\begin{array}{l}\text { Character limit: } 3 \\
\text { ("-" in N. America) }\end{array}$ \\
\hline Minutes & $\begin{array}{l}\text { Distance of the areas centroid north or south of the equator, } \\
\text { measured on a meridian, expressed in minutes. Example: } 35 .\end{array}$ & Character limit: 2 \\
\hline Seconds & $\begin{array}{l}\text { Distance of the areas centroid north or south of the equator, } \\
\text { measured on a meridian, expressed in seconds. Example: } 5 .\end{array}$ & Character limit: 2 \\
\hline
\end{tabular}


Section 9 - Areas Sabject to Spll.

Nkqualo NWR
Men Mem

Soction Menou

Help

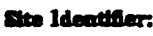

Interatate-5 corr100r

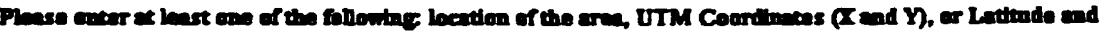
Leartande

Locadearaderess

The Interwete-5 Corr1dor 10 ebe wouthers boumdary of $\mathrm{g}$

tebe rasure.

in aran boom an the Misqually River overelor is

located Juet under the Interstate-s corridor alopd the

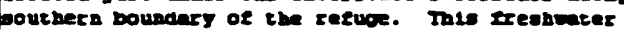

ceroby aree uader the overpans is being constdered is at

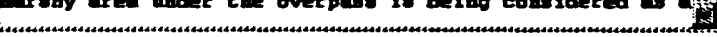

UTM Coersthede:

工

Lertionde

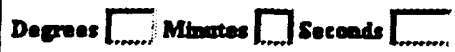

Leartionde

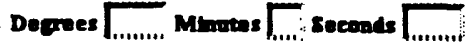

Figure 9-1. Data entry screen: Spill Sensitive Areas. 
Table 9-1. Continued.

\begin{tabular}{|c|c|c|}
\hline Field Name & Content Guidance/Example & Data Entry Tips \\
\hline $\begin{array}{l}\text { Description of } \\
\text { site }\end{array}$ & $\begin{array}{l}\text { Document the extent of the area and relation to the refuge. Describe } \\
\text { characteristics about this SSA that may have particular relevance to } \\
\text { the contaminant assessment (topography, hydrology). Summarize } \\
\text { how materials spilled along the transportation corridor could reach } \\
\text { the refuge. Describe areas within the SSA used by trust species that } \\
\text { could be impacted. Erample: Being an overflow area for the } \\
\text { Nisqually River, this freshwater marsh and water source is } \\
\text { subject to the same potential contaminants as the river, as well } \\
\text { as any run-off from the surrounding industries located on the } \\
\text { erchange of the highway. One of the largest concerns includes } \\
\text { PAH and other organic contamination washing from the } \\
\text { roadways into this area under the underpass. Sampling of the } \\
\text { area is being investigated before this area will be considered as } \\
\text { a possible freshwater source to help manage refuge wetlands. }\end{array}$ & Character limit: 2,000 \\
\hline $\begin{array}{l}\text { Rationale for } \\
\text { selecting this site }\end{array}$ & $\begin{array}{l}\text { Document significance of the area to the assessment. Describe } \\
\text { particular features of the area that may influence movement of } \\
\text { contaminants from a potential spill site onto the area. Summarize } \\
\text { the types of historical spills that have occurred in the vicinity of the } \\
\text { area. Document the extent to which trust species utilize the } \\
\text { potentially impacted area. Summarize any ongoing or historical } \\
\text { investigations or monitoring at the area. If appropriate, comment on } \\
\text { any proposed changes in local transportation corridors that might } \\
\text { increase the likelihood of spilled materials reaching the refuge. } \\
\text { Erample: Activities in and around this area, both historical and } \\
\text { current, lead to the rationale of selecting this site as a site in } \\
\text { which baseline sampling would be very beneficial to the refuge. }\end{array}$ & Character limit: 2,000 \\
\hline $\begin{array}{l}\text { Select the level } \\
\text { of contamination } \\
\text { that applies to } \\
\text { this area }\end{array}$ & $\begin{array}{l}\text { Based on the guidance in this Chapter, select one of the } 4 \\
\text { contamination levels displayed on the data entry screen that best } \\
\text { describes the area. Generally, sites identified in this section are not } \\
\text { associated with significant, known contaminant sources. Areas } \\
\text { suspected of being heavily contaminated should be identified as } \\
\text { PCAs. Erample: Level } 3 \text { - Known contaminant sources, } \\
\text { suspected contaminant presence, no documented contaminant } \\
\text { problems or habitat degradation. }\end{array}$ & $\begin{array}{l}\text { Radio button. Single } \\
\text { selection allowed. }\end{array}$ \\
\hline $\begin{array}{l}\text { Select } \\
\text { contaminant } \\
\text { classifications } \\
\text { linked to this site }\end{array}$ & $\begin{array}{l}\text { Use this picklist to document the types of contaminant classes that } \\
\text { may be present at the site prior to a spill. Erample: Airborne } \\
\text { particulates, oil and grease, other organics, other pesticides, } \\
\text { petroleum products. }\end{array}$ & $\begin{array}{l}\text { Picklist: } 64 \text { selections. } \\
\text { Multiple selections } \\
\text { allowed. Defaults to "No } \\
\text { Selection." }\end{array}$ \\
\hline
\end{tabular}




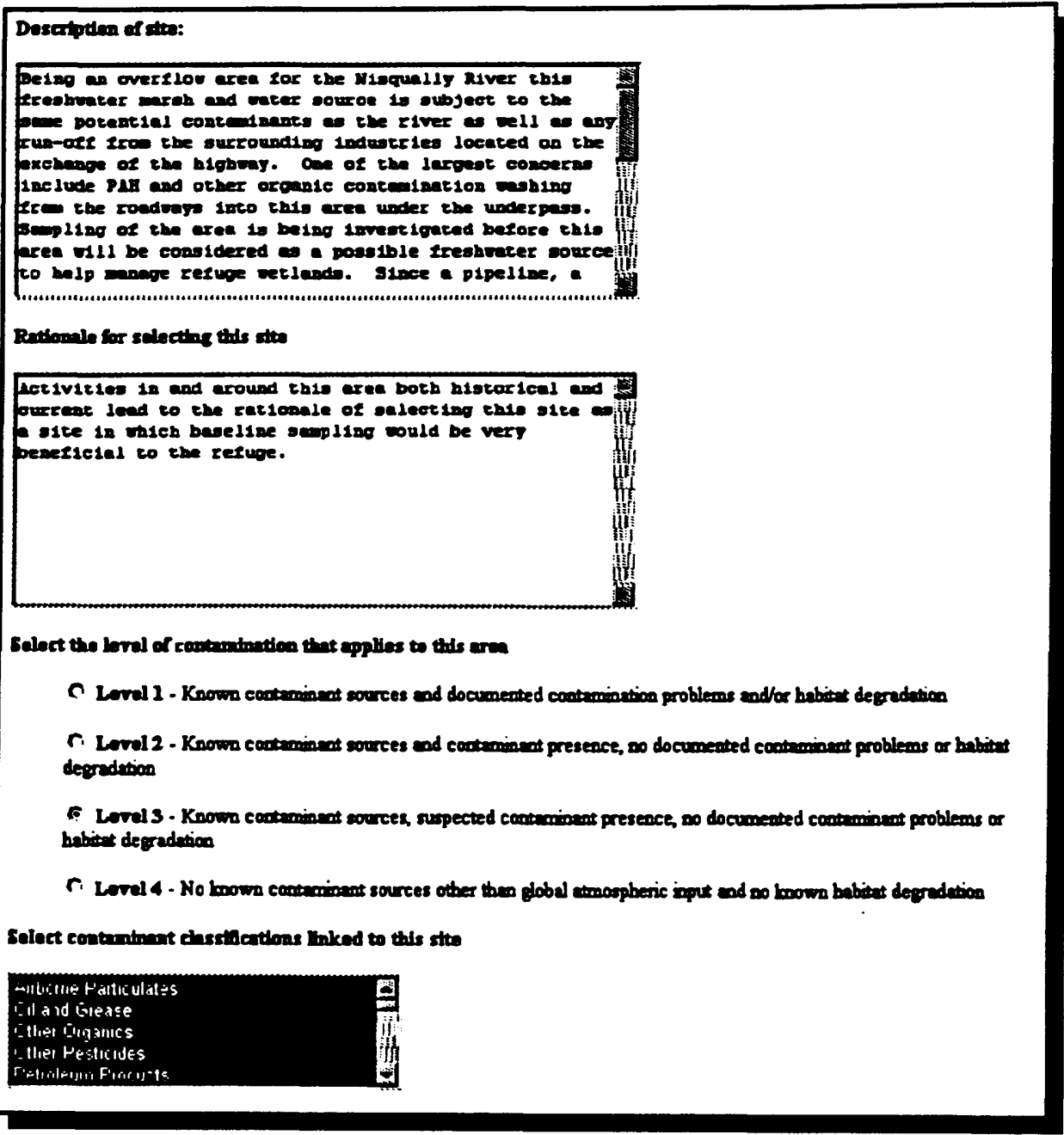

Figure 9-2. Continued. 
Table 9-1. Concluded.

\begin{tabular}{l|l|l}
\hline \multicolumn{1}{|c|}{ Field Name } & \multicolumn{1}{c}{ Content Guidance/Erample } & \multicolumn{1}{c}{ Data Entry Tips } \\
\hline Surface Water & $\begin{array}{l}\text { Pathways described in Section 5: Pathways, are presented in this } \\
\text { record as a picklist. Select the pathway(s) by which released } \\
\text { contaminants may reach the SSA. Example: McAllister Creek, } \\
\text { Nisqually River, Red Salmon Creek. }\end{array}$ & $\begin{array}{l}\text { Picklist. Multiple } \\
\text { pathways can be } \\
\text { selected. }\end{array}$ \\
\hline Ground Water & $\begin{array}{l}\text { Pathways described in Section 5: Pathways, are presented in this } \\
\text { record as a picklist. Select the pathway(s) by which released } \\
\text { contaminants may reach the SSA. Example: McAllister Springs } \\
\text { and Nisqually Groundwater, South Central Pierce County } \\
\text { Aquifer. }\end{array}$ & $\begin{array}{l}\text { Picklist. Multiple } \\
\text { pathways can be } \\
\text { selected. }\end{array}$ \\
\hline Air & $\begin{array}{l}\text { Eight cardinal directions presented in a picklist. Select the wind } \\
\text { direction by which released contaminants may reach the SSA. } \\
\text { Example: South, Southwest. }\end{array}$ & $\begin{array}{l}\text { Picklist. Multiple } \\
\text { pathways can be } \\
\text { selected. }\end{array}$ \\
\hline Biotic & $\begin{array}{l}\text { Potential biological contaminant vectors from Section 5: Pathways, } \\
\text { are listed here. Select those organisms that may transport } \\
\text { contaminants to the SSA. Example: No species listed in Section 5. }\end{array}$ & $\begin{array}{l}\text { Picklist. Multiple } \\
\text { species can be selected. }\end{array}$ \\
\hline
\end{tabular}




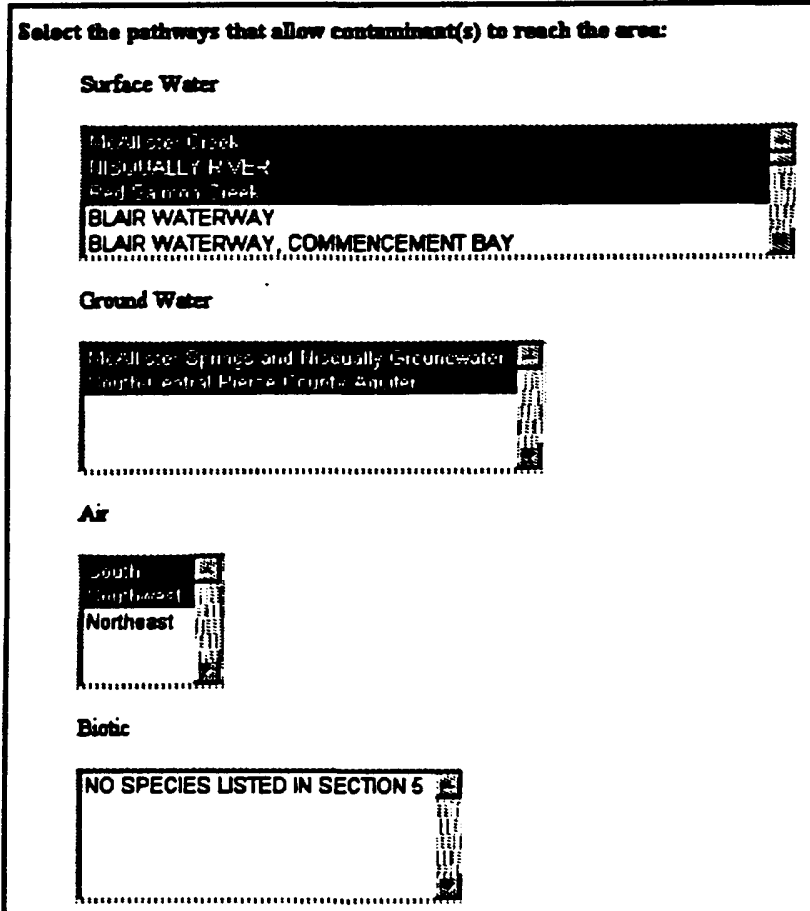

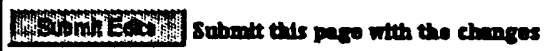

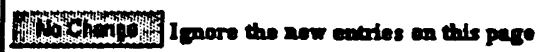
Apersint Delete this recent

Figure 9-3. Concluded. 
wanter 10 H H 1 rative iteport or Thindings

Section 1. Overview
Section 10 of the data management system is used to summarize the significant contaminant issues revealed by the retrospective analysis. By completing the steps in Sections 1-9, the Primary Investigator documents information relating to the refuge and data supporting potential contaminant sources, pathways to the refuge, PCAs, and SSAs. The information collected thus far documents the potential threats but needs to be interpreted and summarized in order to complete the assessment. The Narrative Report of Findings essentially serves as an "Executive Summary." It should be written in clear, concise, non-technical language. This section should describe what was done, what was found, what does it mean, and what should be done. It should summarize the most significant sources and types of contaminants and identify the most likely pathways by which contaminants are transported to the refuge. If the Primary Investigator concludes that a contaminant investigation is warranted to evaluate issues, this summary should contain sufficient information to justify the development of proposals for future project funding.

It may contain management recommendations geared to actions that could be taken to minimize contaminant impacts on the refuge. Examples of management recommendations might include:

- vigilance for contaminant-related effects (i.e., fish kills, dieoffs, reduced oxygen levels)

- follow-up baseline sampling

- protection of sensitive species/habitats

- oil spill contingency planning

- draining of attractive aquatic nuisances

The narrative report should be written as a stand-alone document because it may, eventually, be linked to CIMAS and the Ecological Conservation On-line System (ECOS) or used as a fact sheet in refuge visitor centers. Finally, it should be sufficiently thorough as to serve as the basis for sections of the Comprehensive Conservation Planning (CCP) documents mandated by the enactment of the National Wildlife Refuge System Improvement Act of 1997 (Public Law 105-57-OCT 9, 1997).

This report should contain at a minimum:

- a summary of the refuge's purpose, a description of its size, and its setting

- a preliminary summary of biological resources that might be impaeted by identified contaminants 


\author{
Section 2. Data \\ Management System \\ Operation
}

- a summary of known and suspected contaminant sources and types

- a description of the pathway(s) by which significant amounts of contaminants are likely to reach the refuge or affect trust resources

- an explanation of the ranking and prioritization scheme used to identify primary contaminant issues

- a summation of primary contaminant issues of concern, and

- a recommendation describing the need for future follow-up contaminant investigations.

The information for this section is entered on a single record. Although an unlimited amount of text can be entered into the field provided, the Primary Investigator should try to limit the length of the summary to no more than five pages. This section should be thought of as a concise, executive summary of the CAP. The content of the field can be downloaded from the system as a text file by following instructions provided on the help screen. Text for this field can be composed in word processing software, blocked, copied, and pasted into this field (See Part 1, Chapter 2 - Section 2: Copying and Pasting Information into Data Management System). 
CAP USER's GUIDE 
Section 3. Guidance for Data Entry and Analysis: Narrative Report of Findings

Table 10-1. Field descriptions and examples: Narrative Report of Findings.

\begin{tabular}{l|l|l}
\hline Field Name & \multicolumn{1}{|c|}{ Content Guidance/Erample } & \multicolumn{1}{|c}{ Data Entry Tips } \\
\hline None & See guidance in Overview section of this chapter. & $\begin{array}{l}\text { Character limit: } \\
\text { Unrestricted. Contents } \\
\text { of field can be } \\
\text { downloaded as a text } \\
\text { file by following } \\
\text { directions provided in } \\
\text { the help screen. Use } \\
\text { "carriage returns" in } \\
\text { body of document to } \\
\text { separate paragraphs. }\end{array}$ \\
\hline
\end{tabular}




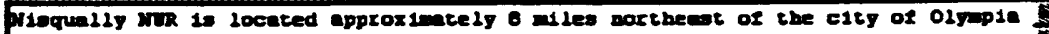
and 17 anles southrest of the eity of Tecon on the Interatate-5 corridor in the brate of Eashinoton. The southers boundary of the retuge 10 Inceratate-5 and the northers ead of che reswo opens inco the lower (wouth) ead of Puget sound. The Hiequally River Defed is a blologleally $51 \mathrm{ch}$ and diverne area at the couchers end of pupec sound that suppores a veriety of babicacs ineluding

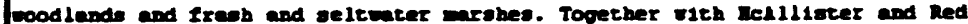
Balwo Creeke, the Hisqualiy River lorm ose of the lexgest remaining

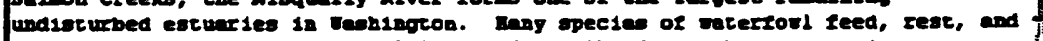
best on the freabrater posch. Salnon and oteelhead we the extrary for paseage

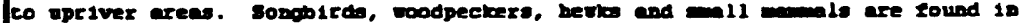
the dense vood lende and grasslands, Elxed conifer lorests on the bluffs above che delte provide perches sor buld eagles, ooprey, and other birds of prey, as rell as the peocing alte for a colong of great blue herons. The miaqualiy Defup's diverelty provldes reating and leeding cree rox algratory vatertorl and aborebixdo along the Pacific rlywy as rell as realdent and overviatering birds.

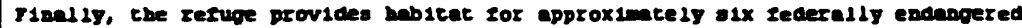

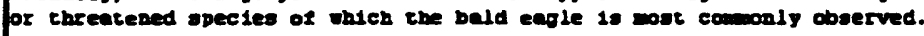

In 1974 the ecquinition of the Hisqually IIR wa approved by the Iracatory B1xd Conservation Condesion and eatebllabed tor magonent by the v.s. T1sh and Gildilfe Service. The min purposea provided by the inter lor land Inelude

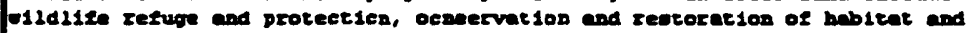

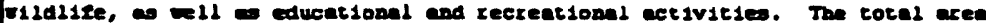

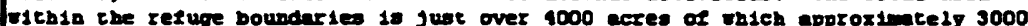

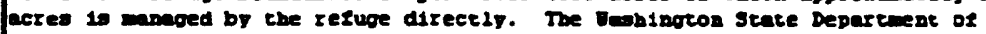

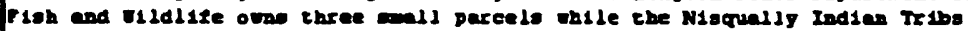

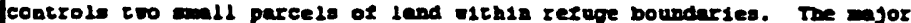

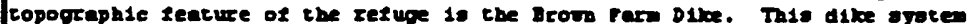

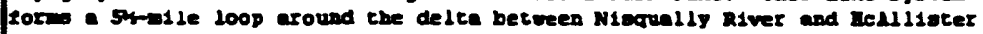
Creek, proteoting this land tron the tidal ection and sele vacer latrusion of puget sound.

Becaure ebe refuge is locaced in an aree that is very urbanized en both the land

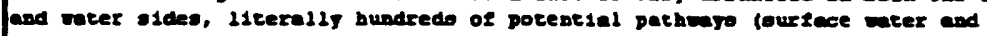
Froundreter primar12y) and sices (TRI, mpLs, CrRCLIS, RCRIS, and aIRs) needed

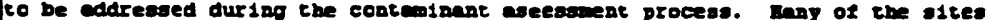
and pathroys listed in the databane are wot of cescerb to the refure lor arveral

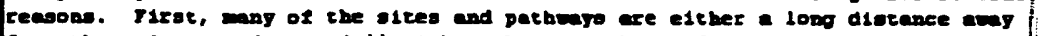
frow the refuge or do not fall fichin the caterabeds of the Misqualig basid.

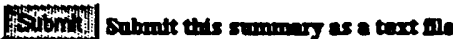

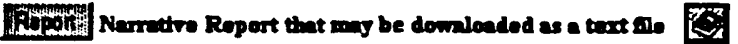

Figure 10-1. Data entry screen: Narrative Report of Findings. 
Appendix A. Data collection checklist.

- Primary Investigator contact information (name, telephone, etc.).

Other important contacts (refuge manager/biologist, local scientists, landowners, local environmental groups, etc.).

- Literature references pertinent to contaminant concerns on the refuge, as well as ecological indices and other pertinent information.

D Important meetings/proceedings.

O Obtain maps of the area to properly evaluate EPA-listed sites, transport pathways, and other geographic features.

- Special significance of the geographic location of the refuge to contaminant concerns (i.e., adjacent to shipping lanes).

Species observed on the refuge and their significance with regard to contaminant issues.

Land cover and use on the refuge and their significance to monitoring activities.

Management activities on the refuge and their significance to contaminant issues. Includes a reference to past baseline or reference sampling conducted.

Off-site areas that may provide a food/water source or source of shelter/nesting to species using the refuge (geographic coordinates).

Known or potential contaminant transport pathways: surface water, ground water, air, and biotic (creeks, washes, hydrologic setting, etc.).

- Any special notes on documented or suspected contaminant concerns (in addition to data from CIMAS) that relate directly to the biodiversity found on the refuge, the mission of the refuge, or protected species found on the refuge.

- Particularly sensitive areas on the refuge that would be adversely affected in the event of a contaminant release from contaminated areas around the refuge (i.e., nesting sites, wetlands, etc.).

Refuge Narrative Reports, Station Management Plans, Refuge Master Plans, or Environmental Impact Statements. 
Appendix B. Description of EPA databases accessed by the CAP data management system and online fate and effects information sources.

\section{EPA Databases}

\section{Toxic Release Inventory System (TRIS)}

Title III of the Superfund Amendment and Reauthorization Act of 1986 (also titled the Emergency Planning and Community Right-to-Know Act of 1986) requires that manufacturers that handle, process, store, or use any of the 650 designated toxic chemicals report releases of the chemicals to the environment. The chemicals reported are known to cause or can reasonably be anticipated to cause in humans: cancer or teratogenic effects, serious or irreversible reproductive dysfunctions, neurological disorders, heritable genetic mutations, or other chronic health effects. Secondly, the chemicals are known to cause or can reasonably be anticipated to cause, toxicity and persistence in the environment, or toxicity and tendency to bioaccumulate in the environment. Reports concerning the chemicals are submitted by the state and maintained by the EPA in its Toxic Release Inventory System (TRIS) database. The most recent data available through the TRIS database is 1996.

\section{Resource Conservation and Recovery Information System (RCRIS)}

The 1976 Resource Conservation Recovery Act (RCRA) regulates hazardous waste generators, transporters and storage, treatment, and disposal facilities. Information for the regulated facilities is maintained on the Resource Conservation and Recovery Information System (RCRIS) database. Hazardous wastes regulated under RCRA include: solvents, ignitable wastes, lead acid batteries, acids, pesticides, dry cleaning filtration residues, heavy metals/inorganics, ink sludges containing chromium and lead, reactives, spent plating and cyanide wastes, and wood preserving agents. The EPA defines three main categories of hazardous waste generators based on the quantity of hazardous waste they generate per month:

(1) conditionally exempt small quantity generators (less than 220 pounds [100 kg] per month)

(2) small quantity generators (between 220 pounds (100 kg) and 2,200 pounds [1,000 kg] per month)

(3) large quantity generators (more than 2,200 pounds [1,000 kg] per month).

\section{Permit Compliance System (PCS)}

All facilities discharging wastewater into waters of the United States are required to have a effluent discharge permit issued through the National Pollutant Discharge Eliminations System (NPDES). The EPA maintains permit and monitoring data for discharging facilities on the Permit Compliance System (PCS) database. The types of regulated pollutants in the PCS database include conventional pollutants (sanitary wastes, oil, and grease), nonconventional pollutants (nitrogen and phosphorus), and toxic pollutants (organics and metals). 
Appendix B. Continued.

Comprehensive Environmental Response, Compensation, and Liability Information System (CERCLIS)

The Comprehensive Environmental Response, Compensation, and Liability Act (CERCLA) of 1980 was amended in 1986 by the Superfund Amendment and Reauthorization Act (SARA). The CERCLA established a federal program responsible for responding to emergency chemical spills and cleaning up inactive and abandoned sites contaminated with hazardous waste. The Comprehensive Environmental Response, Compensation, and Liability Information System (CERCLIS) database is maintained by the EPA to archive information on hazardous wastes and remediation efforts at Superfund sites.

\section{Aerometric Information Retrieval System (AIRS) Facility}

The Aerometric Information Retrieval System (AIRS) Facility Subsystem database is maintained by the EPA to report emission estimates and compliance data required by the Clean Air Act including administrative information, industrial classification, status, description, stack data, emission points, and processes within the facility. AIRS provides release estimates for six criteria pollutants (carbon monoxide, nitrogen dioxide, ozone, sulfur dioxide, lead, and particulate matter smaller than 10 micrometers), volatile organic compounds, and total particulate matter. Estimates are calculated for the total amount of a pollutant released into the air for a calendar year.

\section{Online Fate and Effects Information Sources (Links Not Provided Through CAP Data Management System) \\ U.S. EPA Envirofacts Master Chemical Integrator (EMCI) (http://www.epa.gov/enviro/html/emci/chemref/index.html)}

This website provides links to a variety of information for hundreds of chemicals. It is used to integrate the chemical identifications used in four program system components currently available in Envirofacts (AFS, PCS, RCRIS, and TRIS). This search capability available at the website provides links to available information from the following sources:

- Integrated Risk Information System (IRIS)

- EPA's Office of Air Quality Planning and Standards Hazardous Air Pollutants Fact Sheets

- EPA's Office of Ground Water and Drinking Water Contaminant Fact Sheets

- Agency for Toxic Substance and Disease Registry (ATSDR)'s Public Health Statements

- Links to university and non-governmental sites

\section{U.S. EPA Wildlife Exposure Factors Handbook (http://www.epa.gov/ncea/wefh.htm)}

This online source provides data, references, and guidance for conducting exposure assessments for wildlife species exposed to toxic chemicals in their environment. 
Appendix B. Continued.

\section{U.S. EPA Ecotoxicology Database (http://www.epa.gov/medecotx)}

This database provides a source for locating single chemical toxicity data for aquatic life, terrestrial plants, and wildlife. This site facilitates searches of three multiple databases:

- Office of Research and Development (ORD)

- National Health and Environmental Effects Research Laboratory (NHEERL)

- Mid-Continent Ecology Division, toxicology effects databases

- AQUIRE (aquatic life)

- PHYTOTOX (terrestrial plants)

- TERRETOX (terrestrial wildlife)

U.S. EPA Integrated Risk Information System (IRIS)

(http://search.epa.gov/iris/)

This database contains chemical hcalth risk assessments and regulatory information.

U.S. EPA Integrated Risk Information System (IRIS)

(http://search.epa.gov/iris/)

This database contains chemical health risk assessments and regulatory information.

\section{U.S. EPA Office of Pollution, Prevention and Toxics (OPPT) \\ (http://www.epa.gov/opptintr)}

Provides chemical fact sheets and summaries on exposure, hcalth, environmental effects, regulatory, and contact information.

- Chemical releases

- Chemical information

- Environmental accounting

- High production volume (HPV) chemicals

- Pollution prevention

- Regulatory information

U.S. EPA Agency for Toxic Substance and Disease Registry (ATSDR)

(http://atsdrl.atsdr.cdc.gov:8080/query-phs.html)

This database provides toxicological profiles of chemicals presented as brief information summaries. 
Appendix B. Concluded.

\section{Environmental Defense Fund's Chemical Scorecard \\ (http://www.scorecard.org/chemical-profiles/)}

This website summarizes information about environmental releases, risk assessment values, hazard rankings, and health effects.

Hazardous Substances Data Bank (HSDB)

(http://www.nlm.nih.gov/pubs/factsheets/hsdbfs.html)

This data bank provides toxicologic information on over 4,500 potentially hazardous chemicals. In addition to toxicity data, the system provides information on environmental fate. The data are fully referenced and peer-reviewed by a Scientific Review Panel composed of expert toxicologists and other scientists.

\section{Toxicology Data Network (TOXNET)}

(http://toxnet.nlm.nih.gov/servlets/simple-search?1.4.1.8010)

This website provides a portal to a variety of information related to the toxicity and other hazards of chemicals. From TOXNET, the following databases can be accessed and searched:

- Hazardous Substances Data Bank (HSDB)

- Chemical Carcinogenesis Research Information System (CCRIS)

- Genetic Toxicology/Mutagenicity Data Bank (GENE-TOX)

- Integrated Risk Information System (IRIS) 
Appendix C. Definition of terms.

Area of interest (AOI). ${ }^{1}$ The area surrounding all the pathways, associated with a given transport mechanism, that could account for contaminant inputs that may impact FWS lands. There may be a maximum of four AOIs identified.

Bioaccumulation. ${ }^{2}$ General term describing a process by which chemicals are taken up by aquatic organisms from water directly or through consumption of food containing the chemicals.

Bioassay. ${ }^{2}$ Test used to evaluate the relative potency of a chemical by comparing its effect on a living organism with the effect of a standard preparation on the same type of organism.

Biodiversity. ${ }^{1}$ A conceptual term referring to the variety and variability among living organisms. Diversity can be defined as the number of different items and their relative frequencies. Biodiversity refers to biological diversity, at any level, from genetic variability, assemblages, populations, to communities.

Biomarker. ${ }^{3}$ A biological response to an environmental chemical which gives a measure of exposure and sometimes also a toxic effect. Usually restricted to responses at the level of organization of the whole organism or below.

Environmental contaminants. ${ }^{1}$ Chemicals present at levels greater than those naturally occurring in the environment resulting from anthropogenic or natural processes that potentially result in changes to biota at any ecological level.

Contaminant monitoring. ${ }^{1}$ A long-term ( $>5$ years), systematic, and repetitive sampling program, that includes sample collection, analysis, and data interpretation designed to track the status and trends of the concentrations and effects of contaminants.

Contaminant problem. ${ }^{1}$ A situation resulting from identified contaminants, an event negatively impacting trust resources, or where a trigger level for a contaminant(s), environmental variables, or bioindicator has been reached. This would result in a Contamination Level 1 ranking for the area or contaminant.

Contaminant sampling. ${ }^{1}$ The collection of contaminant data or abiotic/biotic measurements, generally in response to a specific incident or suspected problem.

Contaminant sources: ${ }^{1}$

Nonpoint sources. Contaminant sources that do not have an identifiable location where the contaminants are released into the environment (run-off, global inputs, erosion, transportation).

Point sources. Contaminant sources that have an identifiable location where the contaminants are released into the environment (for example, an effluent pipe, irrigation water return ditch, stack).

Contaminant sources category. ${ }^{1}$ A grouping of contaminant sources (point and nonpoint) that is responsible for the release of similar contaminants.

Contaminant transport mechanism. ${ }^{1}$ The media that physically moves a substance from one location to another. This includes air, water (surface and subsurface), and biota. 
Appendix C. Concluded.

Contaminant transport pathway. ${ }^{1}$ A gradient or path of movement along which contaminants are transported. For the surface water mechanism, the contaminant transport pathway may be a stream, creek, bayou, river, lake, or similar surface water. A contaminant transport pathway is a subset of a contaminant transport mechanism. (Transport pathway is used interchangeably with contaminant transport pathway.)

Ecosystem. ${ }^{1}$ A local complex of interacting plants, animals, and their physical surroundings which is generally isolated from adjacent systems by some boundary, across which energy and matter move; examples include a watershed, ecoregion, or biome.

Impact. ${ }^{1}$ Changes in biotic or biotic components of the ecosystem caused by external sources.

Interior lands. ${ }^{1}$ Those lands that are managed by any of the bureaus within the Department of the Interior. This includes, at a minimum, national wildife refuges, parks, and monuments; waterfowl production areas; fish hatcheries; Bureau of Land Management units; Bureau of Reclamation lands; and Interior facilities (such as administration buildings and surrounding lands).

Medium. ${ }^{1}$ The type of material being sampled (e.g., air, water, sediment, soil, biota).

Pollutant. ${ }^{1}$ A substance (contaminant) or an alteration in the physical environment (low dissolved oxygen, eutrophication, suspended sediments) that is negatively affecting the resource. This could be a direct or indirect effect on the resource.

Potentially contaminated area (PCA). ${ }^{1}$ An area where sampling activities will be conducted for the purpose of confirming the presence of suspected contaminants or effects. The purpose of identifying PCAs is to bring the focus down from the AOI to a specific pathway and even further to the general area on the pathway where sampling activities will be implemented. There may be several PCAs depending on the contaminants and their sources, and the number of transport pathways.

Primary Investigator.' The Primary Investigator is responsible for quality-assuring the information content and conclusions of the contaminant assessment. While portions of the information gathered and reviewed in the assessment may be provided by others (assistant contaminant specialists, refuge staff) the Primary Investigator is the primary point-of-contact for any questions regarding the assessment.

Sensitive species. ${ }^{1}$ Species that are more likely to be affected by a contaminant because of its physiology, behavior, or natural history.

Spill sensitive areas. ${ }^{1}$ An area on FWS lands that is considered to be at risk from hazardous substance spills where baseline data will be gathered to support future natural resource damage assessments.

${ }^{1}$ Operational terms as they apply to the CAP.

${ }^{2} \mathrm{G}$. M. Rand, and S. R. Petrocelli. 1985. Fundamentals of aquatic toxicology.

${ }^{3}$ C. H. Walker, S. P. Hopkin, R. M. Sibley, and D. B. Peakall. 1996. Principles of ecotoxicolgy. 